\title{
Ursachen des Invasionserfolges von Rhododendron ponticum L. auf den Britischen Inseln: Einfluss von Habitat und Genotyp
}

\author{
Dissertation zur Erlangung des Doktorgrades \\ der Mathematisch-Naturwissenschaftlichen Fakultäten \\ der Georg-August-Universität zu Göttingen
}

vorgelegt von

Alexandra Erfmeier

aus Lünen

Göttingen 2004 


\section{7}

Referent: Prof. Dr. Helge Bruelheide

Korreferent: Prof. Dr. Michael Runge

Tag der mündlichen Prüfung: 27.04.2004 


\section{Inhaltsverzeichnis}

1 Ursachen des Invasionserfolges von Rhododendron ponticum L. auf den Britischen Inseln:

Einfluss von Habitat und Genotyp $\quad 5$

Einleitung $\quad 5$

Das Untersuchungsobjekt $\quad 9$

Fragestellungen 11

Ergebnisse $\quad 12$

$\begin{array}{ll}\text { Schlussfolgerungen } & 14\end{array}$

$\begin{array}{ll}\text { Ausblick } & 15\end{array}$

2 Comparison of native and invasive Rhododendron ponticum populations: Growth, reproduction and morphology under field conditions 17

$\begin{array}{ll}\text { Abstract } & 17\end{array}$

$\begin{array}{ll}\text { Introduction } & 17\end{array}$

Material and methods $\quad 20$

$\begin{array}{ll}\text { Study object } & 20\end{array}$

Study sites and sampling design $\quad 20$

Biometrical parameters $\quad 21$

Population parameters $\quad 22$

Statistical analyses $\quad 23$

$\begin{array}{ll}\text { Results } & 24\end{array}$

Biometrical data $\quad 24$

$\begin{array}{ll}\text { Population parameters } & 27\end{array}$

$\begin{array}{ll}\text { Discussion } & 32\end{array}$

3 Invasibility or invasiveness? Effects of habitat, genotype, and their interaction on invasive Rhododendron ponticum (Ericaceae) in the British Isles 37

$\begin{array}{ll}\text { Abstract } & 37\end{array}$

Introduction $\quad 38$

$\begin{array}{ll}\text { Methods } & 40\end{array}$

Study species $\quad 40$

Sampling design and habitat characteristics $\quad 41$

Predictor variables $\quad 41$

Response variables $\quad 42$

Reciprocal transplant experiment $\quad 43$

$\begin{array}{ll}\text { Statistical analyses } & 44\end{array}$

$\begin{array}{ll}\text { Results } & 45\end{array}$

Habitat description $\quad 45$

$\begin{array}{ll}\text { Field correlates } & 47\end{array}$

Reciprocal transplant experiment $\quad 50$

Discussion $\quad 53$

Habitat quality

Invasive genotypes

Habitat-genotype interactions $\quad 55$

$\begin{array}{ll}\text { Conclusions } & 56\end{array}$ 
4 Invasive and native Rhododendron ponticum populations: Is there evidence for genotypic differences in germination and growth?

$\begin{array}{ll}\text { Abstract } & 59\end{array}$

$\begin{array}{ll}\text { Introduction } & 59\end{array}$

Material and methods $\quad 62$

$\begin{array}{ll}\text { Study species } & 62\end{array}$

Experimental material and sampling design $\quad 63$

$\begin{array}{ll}\text { Germination experiment } & 63\end{array}$

$\begin{array}{ll}\text { Growth experiment } & 64\end{array}$

$\begin{array}{ll}\text { Statistical analysis } & 65\end{array}$

$\begin{array}{ll}\text { Results } & 66\end{array}$

Germination responses $\quad 66$

Growth responses $\quad 68$

$\begin{array}{ll}\text { Discussion } & 71\end{array}$

Germination rates $\quad 71$

Germination velocity $\quad 72$

\begin{tabular}{ll} 
Growth rates & 74 \\
\hline
\end{tabular}

$\begin{array}{ll}\text { Mechanisms involved } & 75\end{array}$

$\begin{array}{ll}\text { Literatur } & 77\end{array}$

$\begin{array}{ll}\text { Zusammenfassung } & 85\end{array}$

$\begin{array}{ll}\text { Danksagung } & 87\end{array}$

$\begin{array}{lr}\text { Publikationen } & 89\end{array}$ 


\section{Ursachen des Invasionserfolges von Rhododendron ponticum L. auf den Britischen Inseln: Einfluss von Habitat und Genotyp}

\section{Einleitung}

Biologische Invasionen nichteinheimischer Pflanzenarten sind in den letzten Jahren zunehmend ins Zentrum ökologischer Forschungen gerückt (Elton 1958; Lodge 1993). Dies ist zum einen auf eine Zunahme erfolgreicher Einwanderungen gebietsfremder Arten zurückzuführen (Weber 2003), zum anderen darauf, dass die nachhaltigen Veränderungen, die Invasionsereignisse in Ökosystemen bewirken können, so z.B. eine Verringerung der Artenvielfalt, augenfällig geworden sind (Mooney \& Drake 1986; Drake et al. 1989; Williamson 1996; Vitousek et al. 1996; Parker et al. 1999; Lonsdale 1999; Cox 1999; Mooney \& Hobbs 2000).

Biologische Invasionen sind aber auch deswegen von besonderem wissenschaftlichen Interesse, weil sie großräumige, quasi-natürliche Experimente darstellen, die es erlauben, fundamentale Fragen der Populations- und Synökologie mit klassischen und modernen, z.B. molekulargenetischen Methoden anzugehen (Lodge 1993; Thompson et al. 1995; Sakai et al. 2001). Die Möglichkeiten der Ursachenforschung konzentrieren sich dabei durch unterschiedliche Herangehensweisen auf verschiedene Aspekte der Invasionsbiologie. Ein zentraler Schwerpunkt war lange Zeit die Beschreibung von Invasionsmustern im neu besiedelten Verbreitungsgebiet, bei denen Beobachtungen zur Ausbreitung einer Art im neuen Habitat im Vordergrund stehen (Sukopp \& Starfinger 1995; Wade et al. 1997). Unklar bleibt dabei jedoch, inwieweit die Variation bestimmter Muster im Invasionsgebiet sich tatsächlich von der Variation im Herkunftsgebiet unterscheidet. Systematische Vergleiche nativer und invasiver Vorkommen, die eine solche Einschätzung ermöglichen und somit einen Zusammenhang zwischen bestimmten Merkmalen und dem Invasionserfolg nahe legen, sind dabei erst - sicherlich auch aufgrund des hohen logistischen Aufwands, den eine solche Studie erfordert - in jüngerer Zeit aufgekommen (z.B. Grigulis et al. 2001; Jakobs et al. 2004).

Auf diesem Wege konnte beispielsweise gezeigt werden, dass manche Arten in invasiven Vorkommen über größere Individuen verfügen als im Heimatgebiet oder sich durch insgesamt größere Populationen auszeichnen (Eckert et al. 1996; Jakobs et al. 2004), dass sie über höhere Populationsdichten verfügen (Edwards et al. 1999; Bastlová-Hanzélyová 2001; Paynter et al. 2003; Jakobs et al. 2004), höhere Reproduktionsraten aufweisen als natürliche Vorkommen (Grigulis et al. 2001) oder sich in der Samengröße unterscheiden (Buckley et al. 2003). Ein solcher Vergleich 
ermöglicht es, Hypothesen zu Schlüsselfunktionen von Invasionsprozessen aufzustellen, die in weiteren gezielten Untersuchungen überprüft werden müssen. Reine Beobachtungsstudien können zunächst nur Aufschluss über das phänotypische Erscheinungsbild eines Organismus oder einer Population geben, da der Phänotyp stets das Ergebnis einer Interaktion von Genotyp und Umwelt darstellt.

Dementsprechend haben sich als zentrale Themen der Invasionsökologie die Konzepte "Invasivität" und "Invasibilität" herausgestellt. Untersuchungen zur Invasivität (engl. invasiveness) fragen nach spezifischen 'invasiven' Merkmalen einer Art, die es ihr erlauben, in ein neues Gebiet einzudringen und sich dort auszubreiten. Studien zur Invasibilität (engl. invasibility) betrachten Invasionsprozesse aus der anderen Richtung und fragen nach der Prädisposition oder Anfälligkeit einer Biozönose oder eines Habitats für die Etablierung und Ausbreitung neuer Arten.

Die Frage der Invasibilität wird dabei häufig als Gegenstand der Ökologie von Lebensgemeinschaften verstanden, da es wahrscheinlich ist, dass manche Gemeinschaften anfälliger für Invasionen sind als andere (Crawley 1987; Williamson 1996; Lonsdale 1999; Shea \& Chesson 2002). In diesem Zusammenhang wird beispielsweise häufig eine erhöhte Ressourcenverfügbarkeit im neuen Gebiet als Ursache diskutiert. Diese kann sich zum einen aus der Vergesellschaftung mit konkurrenzschwächeren Arten ergeben (Alpert et al. 2000; Callaway \& Aschehough 2000), zum anderen aber besteht die Möglichkeit, dass das neue Habitat z.B. in edaphischer oder auch klimatischer Hinsicht günstigere Bedingungen bietet und somit eine "Befreiung" (engl. release) von bis dahin im Herkunftsgebiet auf die Pflanze wirkenden Restriktionen ermöglicht. Korrelative und experimentelle Ansätze haben gezeigt, dass eine verbesserte Nährstoffverfügbarkeit den Invasionserfolg einer Art begünstigen kann (Huenneke et al. 1990; Li \& Norland 2001; Hoopes \& Hall 2002). Gleichermaßen kann die Invasibilität eines Ökosystems für eine bestimmte Art auch durch das Klima bestimmt sein (Woodward 1987). Beispiele erfolgreicher Invasionen konnten belegen, dass die klimatischen Bedingungen von Herkunfts- und Invasionsareal einer Art, z.B. hinsichtlich von Minimumtemperaturen oder Wärmesummen, einander sehr ähnlich sind (Beerling et al. 1995; Mihulka \& Pyšek 2001).

Untersuchungen zur Invasivität finden ihren Ursprung bei Baker (Baker \& Stebbins 1965; Baker 1974), der eine Liste von Merkmalen eines "typischen" Unkrauts zusammenstellte, die häufig und vor allem in Kombination miteinander mit invasiven Arten assoziiert sind. Dabei wurden insbesondere die Fähigkeit der sowohl sexuellen als auch vegetativen Reproduktion, ein schnelles Erreichen der reproduktiven Phase, die Anpassung an Stress sowie eine hohe Toleranz gegenüber Variabilitäten der Umwelt genannt. Ausgehend davon haben sich eine Vielzahl von Studien mit verschiedenen spezifischen Merkmalen des Lebenszyklus einer Art (life history traits) als 
potenziellen Merkmalen der Invasivität auseinandergesetzt (Barrett \& Richardson 1986; Rejmánek 1995; Rejmánek \& Richardson 1996; Williamson \& Fitter 1996; Myers \& Bazely 2003). Dabei stehen einerseits Unterschiede zwischen phylogenetischen Gruppen oder Arten im Blickpunkt des Interesses, die den Invasionserfolg beispielsweise mit der Fähigkeit effektiver Reproduktion in Verbindung bringen (Grime et al. 1981; Rejmánek \& Richardson 1996; Radford \& Cousens 2000; Bímová et al. 2003; Brändle et al. 2003; Mandák 2003), andererseits konzentrieren sich viele Studien im interspezifischen Vergleich auf die Bedeutung hoher Wachstumsraten invasiver Arten (Pattison et al. 1998; Reich et al. 1998; Baruch et al. 2000; Grotkoop et al. 2002).

Darüber hinaus sind für invasionsrelevante Merkmale Unterschiede zwischen verschiedenen Populationen von Bedeutung, vor allem zwischen invasiven und nicht-invasiven Populationen einer Art. Ob solche phänotypischen Unterschiede auf unterschiedliche Genotypen zurückzuführen sind oder sich aus der Wirkung der Umwelt ergeben, lässt sich durch sog. common garden-Experimente einschätzen. Dazu ist es erforderlich, dass verschiedene Genotypen, die verschiedenen Herkünften von Pflanzen gleichzusetzen sind, gemeinsam unter gleichen Umweltbedingungen wachsen. Phänotypische Variationen der verschiedenen Genotypen lassen dann Rückschlüsse auf genetisch fixierte Merkmale zu (Schlichting \& Pigliucci 1998; Silvertown \& Charlesworth 2001).

Invasive und native Populationen können sich in einzelnen life history traits unterscheiden, häufig sind dies Merkmale der generativen Reproduktion (Beckstead et al. 1996). Mandák (2003) und Milbau et al. (2003) geben Beispiele für genotypische Unterschiede zwischen invasiven und nativen Populationen hinsichtlich der Keimraten, Buckley et al. (2003) beschreiben Unterschiede in der Samengröße zwischen nativen und invasiven Populationen von Cytisus scoparius. Daneben spielen vor allem solche Merkmale eine Rolle, die invasiven Arten einen Konkurrenzvorteil gegenüber anderen Arten aufgrund eines schnelleren Längenwachstums oder einer erhöhten Biomasseproduktion ermöglichen. Die Studien von Willis et al. (1999), Bastlová \& Kvet (2002) sowie Leger \& Rice (2003) konnten so beispielsweise experimentell zeigen, dass Unterschiede in Wachstumsparametern invasiver und nativer Populationen genetisch verankert sein können (s. aber auch Willis et al. 2000).

Die Überlegenheit mancher Populationen in bestimmten invasionsrelevanten Merkmalen kann zum einen auf die genetische Konstitution der anfänglich eingeführten Individuen und somit der Ausgangspopulationen zurückzuführen sein (Gründereffekte, founder effects). Dahinter steht die Vermutung eines general-purpose genotype, also von Genotypen, die in der Lage sind, in verschiedenen Umwelten (z.B. durch eine hohe phänotypische Plastizität) gleichermaßen gut zu wachsen (Baker \& Stebbins 1965). Andererseits jedoch stellt sich die Frage, ob die genetisch fixierten Merkmale u.U. einen adaptiven Wert haben (Rice \& Mack 1991; Orr \& Coyne 1992; 
Galloway \& Fenster 2000), d.h. ob diese Merkmale eine Anpassung an bestimmte Umweltfaktoren widerspiegeln. Aus Sicht ökologischer Forschung stellen biologische Invasionen natürliche Experimente dar, welche Aufschluss über evolutionäre Prozesse geben können. Häufig liegt zwischen der Einführung einer Art in ein neues Gebiet und ihrer tatsächlichen invasiven Ausbreitung ein längerer Zeitraum (sog. lag-Phase), in welchem aufgrund eines neuen Selektionsdrucks regionale oder lokale Anpassungen, d.h. die Evolution von Adaptationen, erwirkt werden (Kowarik 1995). Wenige Studien haben bislang die Bedeutung lokaler oder regionaler Adaptationen im Kontext von Invasionen untersucht, wenngleich dies für das Verständnis dieser Prozesse relevant ist (Thompson 1998; Galloway \& Fenster 2000; Joshi et al. 2001; Parker et al. 2003).

Der Nachweis spezifischer Adaptationen lässt sich nur im Rahmen großräumiger, reziproker Verpflanzungsexperimente (reciprocal transplantation) erbringen (Leger \& Rice 2003). Bei solchen Experimenten beinhalten die verschiedenen Umwelten eine gleichzeitige Veränderung verschiedener Umweltfaktoren, was im Allgemeinen als Effekt des Herkunfts- bzw. des Zielgebiets gedeutet werden kann. Auf diese Art und Weise lassen sich z.B. lokale oder regionale Spezialisierungen von Genotypen als Adaptationen an eine bestimmte Umwelt, meist das Herkunftsgebiet, verstehen.

Einzelne der genannten Aspekte wurden in zahlreichen Studien separat untersucht. Dennoch sind es meist sowohl die Eigenschaften einer Biozönose als auch spezifische Merkmale der invasiven Populationen, die für eine erfolgreiche Ausbreitung entscheidend sind (Alpert et al. 2000; Milbau et al. 2003). Zudem erschwert gerade die Komplexität der Interaktionen zwischen Art (Genotyp) und Gemeinschaft (Umwelt) das Verständnis der Ursachen einer Invasion (Lodge 1993). Erst die Kombination verschiedener Herangehensweisen und Methoden erlaubt eine umfassendere Einschätzung des Systems sowie der Zusammenhänge und Unterscheidung von Phänotyp, Genotyp und Umwelt (Schlichting \& Pigliucci 1998; Sakai et al. 2001).

Ziel dieser Studie ist es, basierend auf einer Kombination der verschiedenen skizzierten Herangehensweisen und unter Verwendung komparativer, korrelativer und experimenteller Methoden, den Invasionserfolg von Rhododendron ponticum L. auf den Britischen Inseln zu analysieren. Dabei stehen Demographie und Biometrie invasiver und nativer Populationen, die Analyse der Habitateigenschaften, die Frage nach der Evidenz eines invasiven Genotyps (Common Garden) sowie Interaktionen im Sinne von Adaptationen an eine bestimmte Umwelt (Reziproke Verpflanzung) im Vordergrund. 


\section{Das Untersuchungsobjekt}

Rhododendron ponticum L. ist ein aufrechter, immergrüner Strauch der Familie der Ericaceae mit ungeteilten, wechselständigen Blättern. Die Art erreicht eine Größe von 2-8 m (Tutin et al. 1972) und zeichnet sich durch endständige Blüten aus, die in aufrechten Schirmtrauben stehen (Abb. 1). Innerhalb der Gattung wird $R$. ponticum zusammen mit $R$. caucasicum L. sowie den nordamerikanischen Arten $R$. catawbiense Michx. und $R$. maximum L. zur Subsektion Pontica gestellt.

$R$. ponticum verfügt über ein historisch entstandenes disjunktes Areal mit rezenten Vorkommen im nördlichen Klein-Asien, im westlichen Kaukasus (Schwarzmeer-Gebiet) sowie weiteren natürlichen Beständen in Süd-Europa (Zentral- und Südportugal, Südspanien und im östlichen Teil der BalkanHalbinsel) und im Libanon (Meusel et al. 1978;

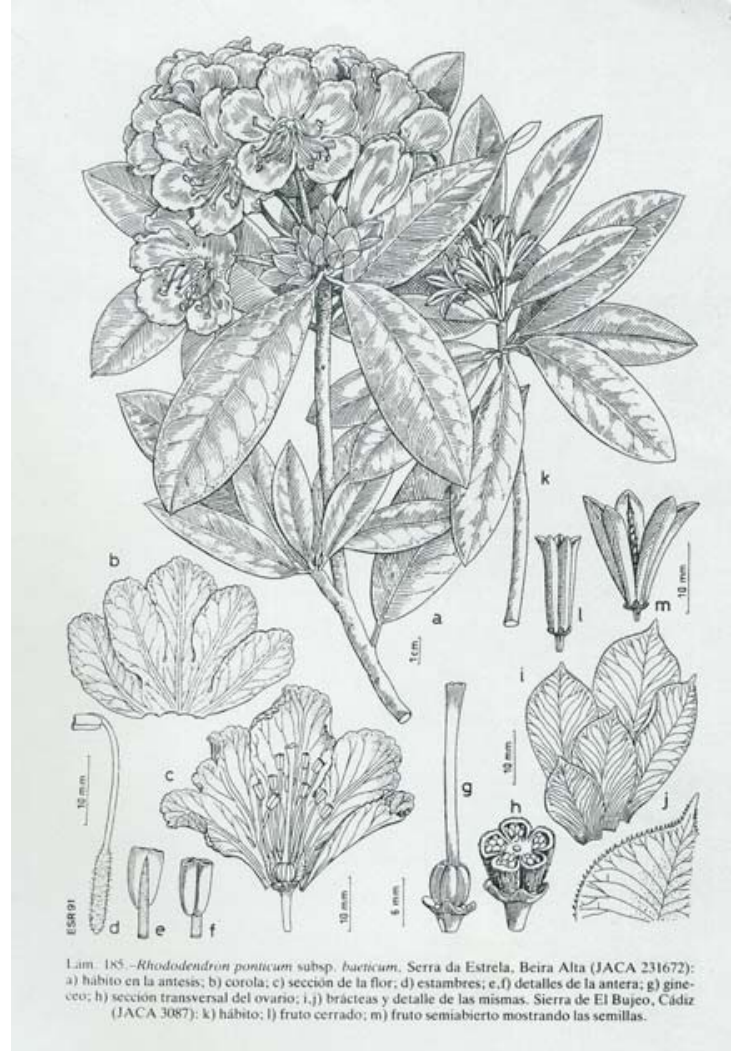

Abb. 1: Rhododendron ponticum ssp. baeticum (Boiss. et Reut.) Hand.-Mazz. (aus: Castroviejo et al. 1993).

Castroviejo et al. 1993). Die Art wird als Teil einer in Europa bis in die Zwischeneiszeiten hinein weiter als rezent verbreiteten immergrünen Gehölzflora angesehen (Mitchell \& Watts 1970; Meusel et al. 1978). Interglaziale Fossilbelege wurden sowohl in den französischen Alpen als auch in Griechenland gefunden und stellen somit Bindeglieder für die disjunkten rezenten Bestände dar (Walter 1968; Walter \& Straka 1970; Cox 1979). Ebenso existieren zwei Fossilfunde in Südirland, die die Vermutung einer ehemals weiteren Verbreitung der Art stützen (Jessen et al. 1959).

Taxonomisch werden die Vorkommen des Schwarzmeer-Gebietes (ssp. ponticum) von denen der Iberischen Halbinsel (ssp. baeticum (Boiss. et Reuter) Hand.-Mazz.) getrennt: Individuen der ssp. baeticum zeichnen sich durch kleinere Blätter mit einem größeren Längen-Breiten-Verhältnis aus als Individuen der Unterart ponticum (Tutin et al. 1972; Davis 1978; Castroviejo et al. 1993).

Südlich des Schwarzen Meeres wächst $R$. ponticum sowohl in laubwerfenden Mischwäldern, als auch in Buchenwäldern aus Fagus orientalis Lipsky (Walter 1968; Cross 1975); östlich des Schwarzen Meeres ist $R$. ponticum ein wichtiger Bestandteil der reichen Wälder der westlichen Kolchis, in welcher die Art im Unterwuchs von Fagus orientalis, Picea orientalis (L.) Link oder Abies nordmanniana (Stev.) Schwach zu finden ist und bis zur oberen Waldgrenze aufsteigt (2000 m ü. NN). In Südspanien und Portugal liegen die Fundorte zwischen 400 und 1200 m ü. NN. 
Hier ist $R$. ponticum unter maritimem Einfluss in immergrünen mediterranen Wäldern vergesellschaftet mit anderen Vertretern der Ericaceae und wächst hauptsächlich entlang von Bachläufen (Mejías et al. 2002). Die isolierten iberischen Rhododendron-Populationen zeigen wenig Verjüngung und gelten als Folge von Landnutzungsveränderungen und langfristigen Veränderungen der Wasserversorgung mittlerweile als in ihrem Bestand gefährdet (Blanca et al. 2000; Mejías et al. 2002).

Im Jahr 1763 wurde $R$. ponticum zum ersten Mal in Großbritannien als Zierstrauch eingeführt (Elton 1958), bereits zwei Jahre später galt die Art in Kew als etabliert, von wo aus sie sich rasch ausbreitete (Bean 1976; Cross 1981; Shaw 1984; Usher 1986). Dabei tritt $R$. ponticum sowohl in Eichen-dominierten (Quercus petraea (Matt.) Liebl.) und in gemischten Wäldern als auch in Heiden, Borstgrasrasen und gelegentlich auch in Dünen in dichten Beständen auf (Gritten 1995). Die Ausbreitung der Art in West-Europa ist ein anhaltender Prozess: weitere Vorkommen sind derzeit aus den Niederlanden, Belgien, Frankreich und Nordwest-Deutschland bekannt (Cox 1979; Mennema et al. 2000; Niinemets et al. 2003). Die von der Ausbreitung von R. ponticum betroffenen Ökosysteme zeichnen sich vor allem durch Verjüngungsschwierigkeiten einheimischer Arten (insbesondere von Quercus und Ilex aquifolium L.) infolge stärkerer Beschattung sowie durch Veränderungen der Bodeneigenschaften durch schwer zersetzbares Laub aus.

Als besonders invasionsbegünstigende Eigenschaft wird für $R$. ponticum eine hohe Schattentoleranz bei gleichzeitiger Befähigung zu hohen Wachstumsraten unter Licht vermutet (Niinemets et al. 2003). Daneben scheinen die Möglichkeit zur vegetativen Vermehrung über Adventivsprosse (Mejías et al. 2002) sowie eine erfolgreiche geschlechtliche Reproduktion von Bedeutung zu sein, welche durch eine hohe Samenproduktion, hohe Keimraten und eine erfolgreiche anemochore Ausbreitung gekennzeichnet ist (Cross 1975, 1981). Des weiteren könnte das milde Klima mit hohen Jahresniederschlägen zur Ausbreitung der Art auf den Britischen Inseln beitragen (Shaw 1984).

Der taxonomische Status der invasiven $R$. ponticum-Vorkommen auf den Britischen Inseln ist noch nicht abschließend geklärt, wenngleich morphologische Merkmale (Cox 1979; Shaw 1984) und molekulargenetische Analysen (Milne \& Abbott 2000) mittlerweile eine iberische Abstammung nahe legen. In gleicher Weise wurde in der Literatur des öfteren eine mögliche Hybridisierung mit den ebenfalls als Ziergehölz eingeführten und phylogenetisch nahe stehenden nordamerikanischen Arten in Erwägung gezogen (Cox 1979; Shaw 1984). Einen deutlichen Hinweis auf eine zugrunde liegende Hybridisierung konnten in letzter Zeit Milne \& Abbott (2000) in ihrer molekulargenetischen Studie zur Herkunft der invasiven $R$. ponticum-Vorkommen erbringen. 


\section{Fragestellungen}

Die genannten Studien haben sich bislang mit einzelnen Aspekten der Invasions- und Populationsbiologie von einzelnen Rhododendron-Vorkommen entweder im Invasions- oder im Herkunftsgebiet befasst. Eine umfassend vergleichende deskriptive und experimentelle Untersuchung sowohl nativer als auch invasiver Populationen steht bislang aus.

In der vorliegenden Arbeit sollen die grundsätzlichen Muster von Genotyp und Habitat sowie ihre Wechselwirkungen miteinander für invasive und native $R$. ponticum-Populationen untersucht werden. Dazu wurden jeweils sechs $R$. ponticum-Populationen in Georgien (als Zentrum der rezenten Verbreitung) und Spanien (als Exklave des Hauptareals) sowie in Irland (stellvertretend für die invasiven Vorkommen) für die Untersuchungen herangezogen (s. Kap. 2, Fig. 1).

Folgende Fragestellungen standen im Vordergrund der Studie:

- Wie ist das phänotypische Erscheinungsbild nativer und invasiver Populationen von Rhododendron ponticum in situ? Zeichnen sich die invasiven irischen Populationen im Gelände durch höhere Wachstumsraten oder andere Reproduktionsmuster aus als native georgische und spanische Populationen? Lassen demographische, biometrische und morphologische Daten Rückschlüsse auf die phylogenetische Abstammung der invasiven Populationen zu? Geben Feldvergleiche Aufschluss über die vermeintlichen Schlüsselfaktoren, die zum Invasionserfolg von R. ponticum beitragen? (Kapitel 2)

- Sind die edaphischen und klimatischen Bedingungen im neuen Habitat für $R$. ponticum günstiger als im natürlichen Verbreitungsgebiet? Welche dieser Faktoren lassen einen Zusammenhang mit den im Feld beobachteten Wachstumsparametern und Etablierungsraten von $R$. ponticum vermuten? Sind invasive Rhododendron-Herkünfte in verschiedenen Habitaten (sowohl im Invasions- als auch im Herkunftsgebiet) erfolgreicher? Zeigen die invasiven Herkünfte eine Anpassung an das Invasionsgebiet? (Kapitel 3)

- Zeichnen sich die invasiven Rhododendron-Herkünfte durch genetisch fixierte höhere Keimraten aus? Gibt es für eine optimale Keimung unterschiedliche Ansprüche an die Temperatur? Reagieren invasive Populationen schneller auf günstige Keimungsbedingungen? Gibt es eine genetische Basis für höhere Wachstumsraten invasiver $R$. ponticum-Populationen? (Kapitel 4) 


\section{Ergebnisse}

In Kapitel 2 werden Untersuchungen vorgestellt, in denen native und invasive Populationen von $R$. ponticum in Felduntersuchungen auf mögliche spezifische phänotypische Merkmale hin untersucht werden, die mit invasiveness in Verbindung gebracht werden können. Dazu wurden für den Zeitraum von drei Vegetationsperioden (1999, 2000 und 2001) demographische, biometrische und morphologische Daten von jeweils sechs Populationen im natürlichen Verbreitungsgebiet in Georgien und Spanien sowie von sechs invasiven Populationen in Irland erhoben. Die Untersuchung zeigte, dass sich die invasiven irischen Populationen vor allem in Parametern des Wachstums signifikant von Populationen nativer Herkunft unterschieden. Invasive Populationen zeigten im Gelände deutlich höhere jährliche Spross-Wachstumsraten und zeichneten sich durch höhere Etablierungsraten der Keimlinge aus. Native spanische Populationen differenzierten sich am deutlichsten durch Gestalt und Alter der Individuen, wohingegen native georgische RhododendronIndividuen sich durch spezifische Blattmerkmale von den beiden anderen Herkünften unterschieden. Die Ergebnisse der Beobachtungen legten nahe, dass zwischen den invasiven irischen und den nativen spanischen Populationen eine engere phylogenetische Beziehung besteht als zu den nativen georgischen Populationen. Die Untersuchungsergebnisse lassen vermuten, dass sowohl spezifische Genotyp-Effekte als auch Umweltbedingungen die invasiven Merkmalsmuster mitbedingen. Im Vergleich nativer georgischer und invasiver irischer Rhododendron-Individuen scheinen die Unterschiede eher auf genetisch festgelegte Merkmale, etwa der Blattmorphologie, zurückzuführen zu sein, während ein Vergleich der spanischen und irischen Individuen insbesondere einen Einfluss günstigerer Umwelt- und Wachstumsbedingungen im Invasionsgebiet vermuten lässt.

Das dritte Kapitel setzt sich mit der Invasibilität des neuen Gebietes auseinander und betrachtet das Wirkungspaar Genotyp versus Habitat. Die Relevanz dieser beiden Faktoren sowie die Möglichkeit spezifischer Genotyp-Habitat-Interaktionen sollten für $R$. ponticum erfasst werden. Zur Charakterisierung des Habitats wurden in jeweils allen nativen und invasiven Populationen in Georgien, Spanien und Irland edaphische und klimatische Parameter erhoben sowie Struktureigenschaften des jeweiligen Habitats bestimmt. Die in den Feldstudien zuvor an markierten RhododendronIndividuen bestimmten Zuwachsraten sowie die Keimungsereignisse im Gelände dienten als response-Variable und wurden mit den Habitateigenschaften korreliert. Die Untersuchungsflächen der irischen Rhododendron-Populationen zeigten ein signifikant höheres Nährstoffangebot als die Flächen der spanischen und georgischen Populationen. Er ergaben sich deutliche positive Korrelationen zwischen den Gehalten an austauschbarem Magnesium und Kalium sowie an 
organischem Kohlenstoff in der obersten Bodenschicht mit den Sprosszuwächsen sowie den Keimlingsdichten im Feld. Die deutlichsten negativen Zusammenhänge zeigten sich mit den Temperatur-Kenngrößen, insbesondere mit der Temperatur-Amplitude im Jahresverlauf.

Zur Einschätzung der Bedeutung etwaiger Adaptationen diente ein Verpflanzungsexperiment mit Rhododendron-Stecklingen aus Populationen aller drei Herkünfte, welche reziprok für die Dauer von 12 Monaten in je eine Untersuchungsfläche der drei Herkunftsländer (jetzt Zielländer) zurück verpflanzt wurden. Zum Ende des Experiments wurden für alle Zielländer die Überlebensraten und der vegetative Zuwachs der Rhododendron-Individuen bestimmt. Es zeigten sich signifikante Effekte der Herkünfte, der Zielländer sowie ihrer Interaktionen bei den Überlebensraten der verpflanzten Stecklinge. Das Zielland Irland erwies sich mit den höchsten Überlebensraten als am günstigsten für alle Genotypen. Es ergab sich jedoch kein klarer Hinweis auf eine generelle Überlegenheit der invasiven Herkünfte. Morphologische Kenngrößen und Wachstumsparameter der ins Invasionsgebiet verpflanzten Individuen zeigten eine große Ähnlichkeit zwischen den nativen spanischen und den invasiven irischen Genotypen. Der Gesamtzuwachs der Sprosse war dabei im Zielland Irland am größten in den irischen Genotypen, wenngleich nicht signifikant verschieden von den spanischen Genotypen. Dieses Ergebnis legt die Vermutung nahe, dass die Invasivität der irischen Genotypen eng an das Habitat des Invasionsgebietes gebunden ist und dass diese Anpassungen nicht den Anforderungen der nativen Habitate entsprechen.

Die vorliegenden Resultate bestätigen, dass alle drei Faktoren Habitat, Genotyp und Anpassung zum Invasionserfolg von $R$. ponticum in Irland beitragen. Unter diesen Faktoren scheinen die günstigen edaphischen und klimatischen Bedingungen im neuen Gebiet den größten Erklärungswert zu haben. Dieses lässt darauf schließen, dass die Invasibilität des neuen Habitats eine Schlüsselrolle für die erfolgreiche Invasion von $R$. ponticum darstellt.

Die vorangestellten Studien haben gezeigt, dass die invasive Ausbreitung von $R$. ponticum auf den Britischen Inseln im Vergleich zum natürlichen Verbreitungsgebiet durch geeignete Umweltbedingungen im Invasionsgebiet begünstigt ist. In Kapitel 4 soll nun speziell die Frage nach einem genetischen Hintergrund für den Erfolg der invasiven irischen Populationen betrachtet werden. Es wurden die Hypothesen getestet, erstens ob die invasiven Populationen tatsächlich über höhere absolute Keimraten verfügen, und zweitens ob Samen invasiver Populationen schneller keimen und höhere Wachstumsraten aufweisen. Dazu wurden Klimaschrankexperimente mit Samenmaterial aus den jeweils sechs nativen georgischen und spanischen sowie invasiven irischen Populationen bei vier verschiedenen Temperaturstufen durchgeführt. Des weiteren erfolgten über einen Zeitraum von eineinhalb Jahren Wachstumsversuche mit Rhododendron-Stecklingen in drei 
verschiedenen Temperatur-Umwelten. Weder in den maximalen Keimraten noch in der optimalen Keimungstemperatur zeigten sich signifikante Unterschiede zwischen den nativen und invasiven Herkünften. Unterschiede ergaben sich in der Reaktionsgeschwindigkeit auf die Temperaturbehandlungen: die irischen Samen reagierten über allen Temperaturstufen mit der schnellsten Keimung. Damit übereinstimmend zeigten die Stecklinge invasiver irischer Herkunft in den Wachstumsversuchen die höchsten relativen Wachstumsraten über alle getesteten Umweltbedingungen hinweg.

Die vorliegenden Ergebnisse geben Hinweise auf eine genetisch fixierte Veränderung (genetic shift) der invasiven Genotypen in Richtung einer gesteigerten Investition in Wachstum und in Richtung einer beschleunigten Keimung. Beide Merkmale tragen dazu bei, die Ausbreitung der Art zu erklären. Als zugrunde liegende evolutive Mechanismen für diese Veränderung werden eine Hybridisierung sowie die Möglichkeit einer Befreiung von bis dahin erfahrenen Beschränkungen in den Herkunftsgebieten diskutiert.

\section{Schlussfolgerungen}

Die Untersuchungen zeigten, dass die Invasibilität des neuen Lebensraums einer der entscheidenden Faktoren für den Invasionserfolg von $R$. ponticum ist. Die Kombination aus einem im jahreszeitlichen Verlauf nur geringen Temperaturschwankungen unterliegenden Klima, und damit verbunden das Fehlen sommerlicher Trockenperioden, mit einer guten Nährstoffversorgung weist einen engen Zusammenhang mit den hohen Wachstumsraten invasiver Rhododendren im Gelände auf. Der Vergleich der Invasibilität der verschiedener Herkunftsgebiete durch reziproke Verpflanzungen konnte die Evidenz eines günstigeren Habitats im neuen Gebiet bestätigen: alle drei nativen und invasiven Herkünfte zeigten die positivste Reaktion auf die Umwelt im Invasionsgebiet.

Die vergleichenden Geländestudien haben gezeigt, dass hohe Wachstumsraten und eine erfolgreiche Keimlingsetablierung im Feld eine zentrale Rolle für die invasive Ausbreitung der Art spielen. Dabei gibt es für Merkmalsunterschiede zwischen nativen und invasiven $R$. ponticum-Populationen zudem auch eine genetische Basis. So bestätigen ähnlich hohe Wachstumsraten der spanischen und irischen Individuen in der irischen Umwelt sowie vergleichbare Größen morphologischer Blattparameter zum einen die hauptsächliche Abstammung der invasiven Individuen von den iberischen Vorkommen und ein grundsätzliches Invasionspotenzial auch für spanische Herkünfte. Darüber hinaus spielt für den Invasionserfolg zudem eine weitere genetische Differenzierung der invasiven Genotypen eine Rolle, die sich in höheren Wachstumsraten und schnelleren Keimungsereignissen unter kontrollierten Bedingungen widerspiegelt. Die gefundenen 
Unterschiede zwischen den Herkünften weisen Anpassungen an das jeweilige Herkunftsgebiet auf. Ähnlich hohe Keimraten aller Herkünfte unter experimentellen optimalen Bedingungen lassen auf ein gleich hohes Reproduktionspotenzial sowohl bei den invasiven als auch den nativen Populationen schließen. Entscheidende Unterschiede ergeben sich in der Keimungsgeschwindigkeit und in ihrer Interaktion mit der Umwelt.

Die Ergebnisse lassen Rückschlüsse auf unterschiedliche Lebensstrategien der invasiven und nativen Rhododendron-Herkünfte zu, dahingehend, dass für native Herkünfte eher Investitionen in die Ausdauer (persistence) denn in die Ausbreitung (dispersal) von Bedeutung zu sein scheinen. Die georgischen Herkünfte zeigen eine starke Anpassung an den eigenen Standort, welcher sich durch fluktuierende und extreme Witterungsereignisse sowie eine vergleichsweise schlechte Nährstoffversorgung auszeichnet, wohingegen spanische Rhododendren im wesentlichen durch klimatische Beschränkungen kontrolliert werden. Die im Gegensatz dazu günstige Umwelt im Invasionsgebiet erlaubt den invasiven irischen Rhododendren den Luxus einer gesteigerten Investition in vegetatives Wachstum bei nur geringem Risiko unerwarteter z.B. witterungsbedingter Störungen oder Ressourcenverknappung. Der Vorsprung einer schnellen Keimung in Kombination mit einer schnellen Investition ins Wachstum verschafft den invasiven Individuen einen Konkurrenzvorteil am irischen Standort.

Zusammenfassend lässt sich schlussfolgern, dass die Selektionsfaktoren Ressourcenverfügbarkeit, abiotische Habitatfaktoren und Stress im Invasionsgebiet von geringerer Bedeutung sind. Dabei scheint die Fähigkeit der irischen Genotypen, das im Vergleich zu den Heimatgebieten gesteigerte Nährstoffangebot in schnelles Wachstum und somit schnelle Reproduktion zu übersetzen, in einer vorhersagbaren verlässlichen Umwelt von adaptivem Wert zu sein.

\section{Ausblick}

Neben der Befreiung von klimatischen und edaphischen Restriktionen spielen möglicherweise weitere biotische Interaktionen eine Rolle. So ist beispielsweise auch ein geringerer Feinddruck im neuen Wuchsgebiet als Selektionsfaktor für die ökologische Strategie der invasiven RhododendronPopulationen denkbar (enemy release hypothesis). Ein trade-off, d.h. ein Abwägen zwischen der Investition in die Abwehr von Feinden und der Investition in kompetitive Fähigkeiten kann sich im Falle einer Befreiung von etwaigen natürlichen Gegenspielern z.B. in schnellerem vegetativen Wachstum äußern (Blossey \& Nötzold 1995; Maron \& Vilà 2001; Keane \& Crawley 2002). Es gibt durchaus Grund zu der Annahme, dass solche Regulationsmechanismen auch für R. ponticum greifen können. Herbivorie durch Insekten ist für Rhododendron ponticum bekannt (Usher 1986), und Cross (1975) nennt zudem eine Reihe von Pilzen, Bakterien und Viren, die im Prinzip 
Rhododendron ponticum befallen können. Beobachtungen im Gelände haben gezeigt, dass BlattHerbivorie sowohl in den nativen als auch in den invasiven Beständen auftritt, wenngleich im Invasionsgebiet solche Muster weniger häufig anzutreffen waren. Inwieweit diese Beobachtungen ein generelles Muster widerspiegeln und ob native Populationen entsprechend eine bessere Anpassung daran zeigen, muss in weiteren Untersuchungen geprüft werden.

Darüber hinaus ist es neben den in dieser Arbeit untersuchten Aspekten denkbar, dass der genetischen Konstitution der Populationen eine besondere Bedeutung zukommt. Eine hohe genetische Variabilität oder Diversität der invasiven Populationen kann ihre Ansiedlung und Ausbreitung im neuen Gebiet unter unterschiedlichen Umweltbedingungen erleichtern (s. beispielsweise Martins \& Jain 1979). Auch können die genetisch verankerten Unterschiede zwischen invasiven und nativen Herkünften auf eine mögliche introgessive Hybridisierung mit verwandten Arten zurückzuführen sein (s. Stebbins 1969; Rieseberg \& Carney 1998; Ellstrand \& Schierenbeck 2000). Dass invasive Arten häufig Hybride aus eingeführten und heimischen Arten sind, hat sich in mehreren Studien gezeigt (z.B. Albert et al. 1997; Anttila et al. 1998; Ayres et al. 1999; Gaskin \& Schaal 2002; Schweitzer et al. 2002), und auch für R. ponticum haben die RFLPAnalysen von Milne \& Abbott (2000) eine Hybridisierung hauptsächlich mit der nordamerikanischen Art $R$. catawbiense, aber auch mit $R$. maximum mittlerweile nachgewiesen. Eigene AFLP-Analysen (Amplified fragment length polymorphism), deren Ergebnisse nicht Bestandteil dieser Arbeit sind, konnten diesen Befund nicht bestätigen. Dazu wurde Blattmaterial aus allen in dieser Studie untersuchten Populationen sowie jeweils weiteren sechs Populationen von $R$. catawbiense und $R$. maximum systematisch beprobt. Clusteranalysen auf Basis der DNA-Fragmente ergaben keine engere Verwandtschaft der nordamerikanischen Arten zu den invasiven Herkünften. Zudem zeigten die bisherigen Analysen keine höhere genetische Diversität der irischen Populationen. Somit gibt es keinen Hinweis darauf, dass Hybridisierungsereignisse zur Erklärung der erfolgreichen Ausbreitung von R. ponticum beitgetragen haben.

Diese Befunde stärken die Annahme, dass ein verminderter Selektionsdruck im Invasionsgebiet maßgeblich ist für die erfolgreiche Ausbreitung von Rhododendron ponticum und unterstützen somit die Schlussfolgerung einer hohen Empfänglichkeit des neuen Habitats. 


\title{
Comparison of native and invasive Rhododendron ponticum populations:
} Growth, reproduction and morphology under field conditions

\begin{abstract}
The objective of this paper is to identify the factors that promote the invasiveness of Rhododendron ponticum L. by the means of comparative field observations. Rhododendron ponticum (Ericaceae) is an evergreen shrub with a natural distribution in the Mediterranean and Black Sea area and was introduced to the British Isles in 1763. Thenceforward, the species has been considered as a major threat to natural ecosystems.

We compared native and invasive populations of Rhododendron ponticum with respect to trait patterns that are associated with invasiveness. Six populations each in the natural part of its range, in Georgia (Caucasus) and Spain as well as six invasive ones in Ireland were examined with regard to biometrical, morphological and ecological characteristics.

Invasive Irish populations differed from non-invasive ones mainly in growth patterns and showed much higher rates of annual shoot growth in the field and higher rates of seedling recruitment. In contrast, native Spanish populations were discriminated by their shape and age; whereas native Georgian rhododendron, above all, showed distinctive leaf characteristics. In general, the relationship between Irish and Spanish populations was closer than to the Georgian ones. Our results suggest that both genotype and environment account for the trait pattern found in Irish populations. Differences in genetically fixed traits had a greater effect in morphological differences to Georgian provenances. In contrast, the invasive Irish rhododendron were favoured by a more benign environment than the Spanish populations.
\end{abstract}

Keywords: clonality, growth rate, invasiveness, leaf characteristics, seedling recruitment

\section{Introduction}

In recent years, biological invasions by non-native species have become a focus of ecological research mainly because of their profound impact on ecosystems (Mooney \& Drake 1986; Williamson 1996; Parker et al. 1999; Lonsdale 1999). Invasiveness matters, in particular, since many invasive species have been reported to exert high reproduction pressure on the community invaded (Noble 1989) or to be highly productive and to attain a larger size in their new area (Crawley 1987; Blossey \& Nötzold 1995). In this context, especially high relative growth rates (RGRs), that can be ascribed to specific leaf attributes of the invading plants, have been regarded as 
a responsible component role in invasion processes (Cornelissen et al. 1998; Grotkoop et al. 2002). However, there is no straight forward way to detect crucial life history traits of an invasive species, since ecological, physiological, morphological and genetic characters or a specific combination of them have to be considered (Baker \& Stebbins 1965; Baker 1974; Williamson 1996). Moreover, the success of a species in a new habitat is mainly due to how the species' characteristics interact with the new environment (Lodge 1993).

In studies on invasion ecology, we consider a multi-stage approach useful: 1) observation of the invasion event in the new area, 2) comparison of native and invasive populations in the field and then 3) experimental demonstration of the impact of putative key factors.

The obvious first step is to study a species' spread in the new habitat (Sukopp \& Starfinger 1995; Wade et al. 1997) and to compare these observations with other invasion patterns (Lodge 1993). In this way, e. g., Kowarik 1995 was able to reconstruct introduction and spreading dynamics of woody species in Germany and, thus, reveal the relevance of a lag phase between a species' introduction and the initiation of its invasion process. Although such observational studies offer useful hints on possible key factors promoting invasiveness, they cannot answer questions as to whether these factors are actually the crucial ones. To assess the strength of the effects of these factors, experimental approaches are necessary (Bruelheide 1999; Lavorel et al. 1999). Consequently, there are many studies that immediately focus on phase 3 , thus, comparing specific traits experimentally (Thébaud et al. 1996; Weber \& D'Antonio 1999; Siemann \& Rogers 2001).

However, at this point, there is no evidence that these traits are also operative in the species' native habitat, which should be analysed in the second step. Surprisingly, there are only few studies that take native and invasive ranges into account. In any case, these comprehensive approaches are laborious and difficult to realise. Nevertheless, in this manner, Grigulis et al. (2001), e. g., were able to demonstrate that for Echium plantagineum the rates of seedling establishment from the seed bank and the rate of incorporation into the seed bank were higher in the invaded area in Australia than in native Mediterranean populations. Investigations in native and exotic populations of Cytisus scoparius in Europe and Australia have shown that absolute seedling mortality is higher in the introduced range (Paynter et al. 1998; Sheppard et al. 2002 and references therein). In any case, a higher variability in seedbank patterns and in the transition from seedbank to seedling due to habitat specific differences more than compensates for this loss (Sheppard et al. 2002). Providing a systematically quantifying comparison of an invasive species both in its native and invasive range can, therefore, narrow down the spectrum of possible key factors. 
The objective of this study is to apply this procedure to Rhododendron ponticum. This paper is the first of a consecutive series of studies that intend to elucidate the connection of both the ecological and the genetic background of this species’ invasion success.

Rhododendron ponticum L. is a suitable system for studying an invader's ecology both in its new and native habitats. Since its introduction to the British Isles in the $18^{\text {th }}$ century the species has spread into natural ecosystems with massive invasions. It is currently regarded as one of the 'top twenty’ British alien plant species (Crawley 1987).

Rhododendron ponticum has a disjunct distribution. Formerly widely spread in Europe during the Tertiary and Pleistocene (Jessen et al. 1959; Mitchell \& Watts 1970; Meusel et al. 1978), the species presently occurs in the Western Caucasus region, Asia-Minor, in the eastern part of the Balkans, as well as in an outpost on the southern part of the Iberian peninsula (Fig.1). Although range expansion in Western Europe is still in progress, native Rhododendron stands are described differently, either as having stable populations in specific habitats (e.g. in Georgia) or as declining populations of a severely endangered species, e.g. in Southern Spain, (Blanca et al. 2000). The origin of invasive Rhododendron populations is still being discussed. Milne \& Abbott (2000) recently used restriction fragment length polymorphisms of chloroplast DNA to show the existence of a mostly Spanish provenance for this species.

A few studies have focused on the population biology of Rhododendron ponticum, to date. In particular, invasive British and Irish populations have been the focus of numerous scientific investigations (Cox \& Hutchinson 1963; Cross 1975; Cox 1979; Shaw 1984; Tabbush \& Williamson 1987). Recent studies dealt with the ecology and control of Rhododendron ponticum in Turkey (Esen 2000). The basic parameters of reproductive biology and critical life stages in Spain were studied by (Mejías et al. 2002), and plasticity parameters were analysed in a Spanish and a Belgian population (Niinemets et al. 2003). Thus, no research project has taken the total range into consideration, although this has been clearly recognized as necessity (Mejías et al. 2002).

The objectives of this study are to make a general comparison of Rhododendron ponticum's native and introduced range, with a special focus on patterns of growth and morphology. We hypothesize, in particular (i) that invasive Irish populations show higher growth rates in the field than native occurrences, and (ii) that reproduction is more successful in the new area. Finally, our aim is to point out the most possible key factors promoting invasiveness that should be tested in subsequent experiments. 


\section{Material and methods}

\section{Study object}

Rhododendron ponticum L. (Ericaceae) is an erect, evergreen shrub attaining a height of 2-8 m (Tutin et al. 1972). Taxonomical differentiation exists between plants of the Black Sea area (ssp. ponticum) and Iberian occurrences (ssp. baeticum) based on distinctive traits in leaf morphology: individuals assigned to the ssp. baeticum in general have smaller leaves and a larger length-widthratio than individuals of ssp. ponticum (Tutin et al. 1972; Davis 1978; Castroviejo et al. 1993). $R$. ponticum ssp. ponticum is an element of deciduous summergreen mixed forest and beech forest communities in the pontic lowlands and extends up to the subalpine level. In Southern Spain and Portugal Rhododendron ponticum ssp. baeticum is either associated with mediterranean sclerophyllous forests under maritime influence, mainly along creeks, or a scrubland element of humid mountain ranges (Mejías et al. 2002). Iberian populations can be found between 400 and $1200 \mathrm{~m}$ a. s. 1.

Introduction to the British Isles dates back to the year 1763 (Elton 1958). Since that time, the species has extended its range in Western Europe, where it exerts a major impact on natural communities. Particularly in Great Britain and Ireland Rhododendron ponticum has invaded oakdominated Quercus petraea- and mixed forests as well as heaths and bogs. The present invasion tendency appears to be eastward with actual occurrences in the Netherlands and Belgium as well as in Northwest Germany (Niinemets et al. 2003; personal observations).

The species propagates by producing numerous small seeds. Vegetative growth occurs by layering branches on the ground. Cover with litter can lead to rooting, subsequent separation of branches from the parental plant and finally result in independent ramets that seem to have no obvious connection to each other. Nevertheless, in Britain, vegetative spread is very limited, Rhododendron ponticum is not able to sucker (Shaw 1984). Cross (1975) pointed out that Irish Rhododendron axes lack mechanical strength so that the plant extends rather laterally than vertically.

\section{Study sites and sampling design}

Study areas were chosen across the species' entire range; thus, including the species' central range in the Black Sea area, on the Iberian peninsula and its invasive occurrences in the British Isles. In Georgia, Spain and Ireland six populations each were studied (Table 1). All study sites were confined to forests because these are the typical habitats in Georgia and Spain. In addition, the focus on forests provided also comparable growth conditions among all sites. Selection of study sites was performed by covering the altitudinal and geographical range within each country including 


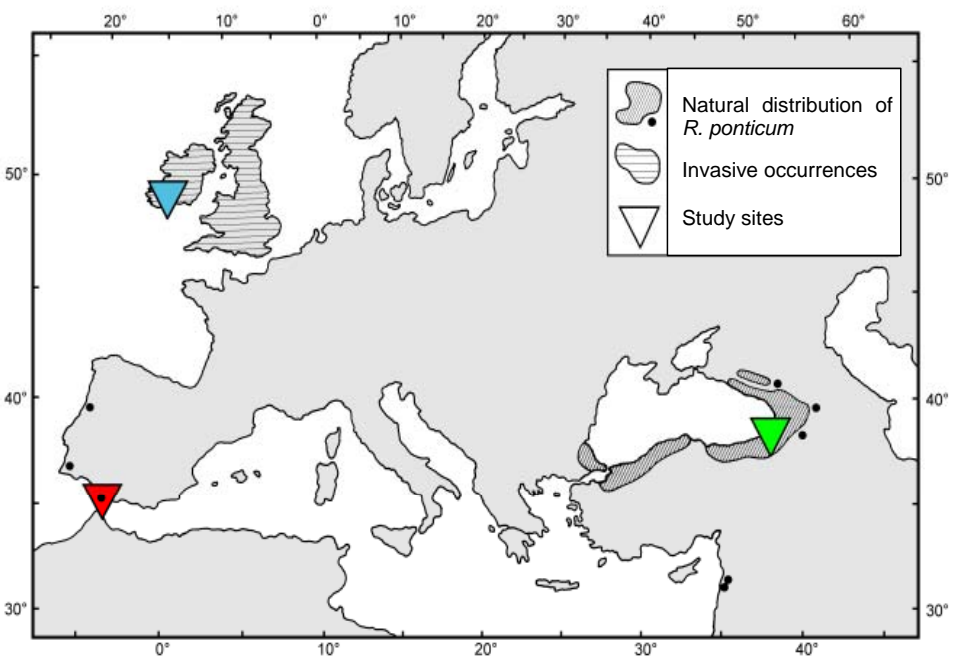

Fig. 1. Native distribution and invaded areas of Rhododendron ponticum (after Cross 1975) and location of study sites. Each symbol comprises six study sites

different forest types with the intention of sampling the span of possible occurrences. All study sites faced north and had a similar slope of 10 to $20^{\circ}$. A single Georgian site (F) had to be located along a steeper inclination due to a lack of alternatives, whereas Spanish sites, in general, were less steep. In Georgia and Ireland, study sites were located along a transect of a length of $150 \mathrm{~km}$ and $250 \mathrm{~km}$, respectively. The transect followed a west to east gradient of decreasing annual precipitation. Due to sparse Iberian occurrences, the Spanish populations of Rhododendron ponticum had shorter distances between them (maximum $50 \mathrm{~km}$ ). The Spanish sites can be assigned to two groups: four sites located in humid forests of the Aljibe Mountains in small river valleys ('canutos') and two further locations near the Strait of Gibraltar with a more maritime influence, partially under cloud forest conditions.

The sampling survey within a population was carried out systematically. At each site, a square of $16 \mathrm{~m} * 16 \mathrm{~m}$ was set up in a homogenous Rhododendron population and divided into a grid with a 4m mesh size. Since the grid was laid out from an arbitrary point and strictly orientated towards north, the exact position of the 16 grid points was random. In five Spanish populations plots with a length of $32 \mathrm{~m}$ and a width of $4 \mathrm{~m}$ were established along both sides of a creek. Each plot covered a total area of $256 \mathrm{~m}^{2}$.

\section{Biometrical parameters}

At each site, 16 individuals were selected for biometrical measurements. The individual with a minimum height of $50 \mathrm{~cm}$ that was nearest to the grid point was chosen for biometrical survey and permanently marked for consecutive recording. Study sites were established and investigated from November 1999 to February 2000 and populations were repeatedly measured in summer 2000 (July to September) and 2001 (August to October). 
Table 1: Names, locations and vegetation characteristics of the studied populations.

\begin{tabular}{|c|c|c|c|c|c|c|c|c|c|c|}
\hline \multicolumn{2}{|c|}{ Country Pop. } & \multirow[t]{2}{*}{ Location } & \multirow{2}{*}{$\begin{array}{l}\text { Elevation } \\
\text { [m a.s.I.] }\end{array}$} & \multirow[t]{2}{*}{ Latitude } & \multirow[t]{2}{*}{ Longitude } & \multirow{2}{*}{$\begin{array}{c}\text { Aspect } \\
\left.{ }^{\circ}\right]\end{array}$} & \multirow{2}{*}{$\begin{array}{c}\text { Slope } \\
\\
\left.{ }^{\circ}\right]\end{array}$} & \multirow{2}{*}{$\begin{array}{c}\text { Cover } \\
\text { R.p. } \\
\text { shrub } \\
\text { layer } \\
{[\%]}\end{array}$} & \multirow{2}{*}{$\begin{array}{c}\text { Cover } \\
\text { R.p. } \\
\text { herb } \\
\text { layer } \\
{[\%]}\end{array}$} & \multirow{2}{*}{$\begin{array}{c}\begin{array}{c}\text { Canopy } \\
\text { cover }\end{array} \\
{[\%]}\end{array}$} \\
\hline & & & & & & & & & & \\
\hline Geo & $A$ & Banis-Khevi & 980 & N 41 $53.020^{\prime}$ & E $043^{\circ} 21.188^{\prime}$ & 336 & 22 & 70 & 30 & 75 \\
\hline Geo & $\mathrm{B}$ & Keda-Akutsa & 500 & N $41^{\circ} 35.557^{\prime}$ & E $041^{\circ} 57.107^{\prime}$ & 320 & 15 & 60 & 4 & 100 \\
\hline Geo & C & Dandalo & 910 & N 4138.035' & E $042^{\circ} 07.588^{\prime}$ & 10 & 18 & 60 & 10 & 65 \\
\hline Geo & $\mathrm{D}$ & Botanical Garden, Batumi & 85 & N 41ํㄴ.975' & $\mathrm{E} 041^{\circ} 43.219^{\prime}$ & 37 & 14 & 60 & 20 & 80 \\
\hline Geo & $E$ & Djarnali & 175 & N 413․165' & E $041^{\circ} 36.611^{\prime}$ & 340 & 15 & 50 & 10 & 74 \\
\hline Geo & $\mathrm{F}$ & Mtirala & 960 & N 4139.119' & E $041^{\circ} 47.184^{\prime}$ & 360 & 30 & 50 & 10 & 55 \\
\hline Esp & $G$ & Garganta de Puerto Oscuro & 790 & N 36³0.919' & W $005^{\circ} 37.416^{\prime}$ & 105 & 8 & 80 & 4 & 85 \\
\hline Esp & $\mathrm{H}$ & Garganta de Passada Llana & 760 & N 36³0.403' & W $005^{\circ} 35.960^{\prime}$ & 122 & 7 & 60 & 10 & 65 \\
\hline Esp & 1 & Arroyo del Montero & 660 & N 36²9.650' & W $005^{\circ} 35.962^{\prime}$ & 229 & 4 & 80 & 10 & 80 \\
\hline Esp & $\mathrm{K}$ & Garganta de Enmedio & 445 & N 36³2.085' & W $005^{\circ} 38.222^{\prime}$ & 357 & 5 & 60 & 10 & 70 \\
\hline Esp & $\mathrm{L}$ & Llanos del Juncal & 740 & N 3606.334' & W $005^{\circ} 32.468^{\prime}$ & 32 & 10 & 60 & 4 & 70 \\
\hline Esp & M & Rio de la Miel & 430 & N 36º6.486' & W $005^{\circ} 31.306^{\prime}$ & 67 & 10 & 70 & 10 & 80 \\
\hline Ire & $\mathrm{N}$ & $\begin{array}{l}\text { National Park Killarney, } \\
\text { Torc Mnts. }\end{array}$ & 60 & N $52^{\circ} 00.161^{\prime}$ & W $009^{\circ} 30.301^{\prime}$ & 350 & 15 & 40 & 10 & 65 \\
\hline Ire & $\mathrm{O}$ & $\begin{array}{l}\text { National Park Killarney, } \\
\text { Ladies View }\end{array}$ & 35 & N 51ํ58.394' & W $009^{\circ} 35.494^{\prime}$ & 14 & 12 & 40 & 20 & 60 \\
\hline Ire & $\mathrm{P}$ & Glengariff & 35 & N 51ํㄴ.388' & W $009^{\circ} 33.820^{\prime}$ & 297 & 18 & 60 & 10 & 55 \\
\hline Ire & $\mathrm{Q}$ & Galtee Mnts. & 180 & N $52^{\circ} 22.452^{\prime}$ & W $007^{\circ} 58.744^{\prime}$ & 179 & 15 & 80 & 10 & 70 \\
\hline Ire & $\mathrm{R}$ & Knockmealdown Mnts. & 220 & N 52 $15.535^{\prime}$ & W $007^{\circ} 57.065^{\prime}$ & 353 & 22 & 80 & 10 & 50 \\
\hline Ire & $\mathrm{S}$ & Greenan,Wicklow Mnts. & 120 & N $52^{\circ} 55.945^{\prime}$ & W $006^{\circ} 18.555^{\prime}$ & 31 & 10 & 80 & 80 & 65 \\
\hline
\end{tabular}

In the winter of 1999/2000 the biometrical parameters height, extension and basal diameter of each individual were measured. For each marked individual the highest sprout with a terminal vegetative bud was chosen, and the number of shoots and leaves were recorded with reference to the previous year's internode. Internode elongation of the preceding vegetation period was regarded as the annual increase in shoot length and recorded as growth parameter. Measurements of growth parameters were repeated in summer 2000 and 2001. Each time the increase in shoot length and basal diameter, the incidence and the number of new branches and the number of leaves were recorded. Leaf morphology was described in 1999 by length, width and shape. Shape was defined as length from leaf base to widest width divided by length. In total, we measured 2673 leaves.

\section{Population parameters}

To analyse population structure, a density survey was conducted along a transect of $1 \mathrm{~m} \cdot 1 \mathrm{~m}$ subplots diagonally aligned within the study square. Within a total of 16 subplots per population, all detected Rhododendron individuals were recorded. We counted seedlings, saplings and individuals of different height classes. For each individual the basal diameter at soil surface was measured in two directions. The proportion of clonality within a population was assessed in the transect survey by classifying each encountered individual as derived from either sexual or vegetative reproduction. 
Identification of ramets in the populations followed recognition of layerings combined with simultaneous adventitious rooting.

\section{Fruit set}

The number of both generative buds and racemes was counted for each of the 16 target individuals marked per site in 1999. Transition from buds to racemes was determined by repeated counting in 2000. In 2000, we collected 10 racemes each from individuals with sufficient fruits. Successful maturing was then quantified by counting the proportion of capsules containing seeds on the total capsule set within a raceme. We calculated fruit set as the ratio of mature fruits to total fruits per individual. The impact of self-fertilisation was tested by the use of gauze bags in the winter of 1999/2000. Within each population, eight generative buds of different individuals were chosen and bagged with gauze bags of a mesh width of $2 \mathrm{~mm}$ to exclude insect mediated pollination. In the summer of 2000, the bagged fruits were gathered to analyse fruit set. The next adjacent non-bagged raceme was collected as a reference for fruit set.

\section{Age determination}

Age determination of Rhododendron individuals referred to ramets. Due to vegetative reproduction the genet might be much older. Within each population ten randomly chosen individuals were cut for counting growth rings. The associated diameters were measured to generate a population specific linear regression model. Age of target individuals and of transect individuals was then estimated referring to the particular basal diameters.

\section{Statistical analyses}

\section{Survival of leaves}

The survival rate of leaves was defined by calculating the transition probabilities for encountered leaves in 1999 and 2000 to the year 2001. Furthermore, in 2001 all existing leaves were counted and dated back to the year of their apparent emergence with reference to the respective internode. For Irish individuals, we encountered the incidence of several internodes per year in 2000 and 2001. In these cases, survival rate of leaves was then adjusted to the correct age of internode.

\section{Data analysis}

All calculated parameters were tested for normal distribution (proc univariate, Shapiro-Wilkstatistics, SAS Institute 2000). Since most of the parameters were not normally distributed, the data were transformed into ranks. We then employed a nested ANOVA model, with main factor ‘country’ (fixed) and ‘population’ (random) nested within country (proc glm; SAS Institute 2000). 
Post-hoc tests were performed using Ryan-Einot-Gabriel-Welsch (REGWQ) multiple range tests. If not stated otherwise, significance levels for all tests were set at $\alpha=0.05$. In all figures, data are presented as median values with quartiles and the range between minimum and maximum.

Simple regression analysis was used to examine pairwise relationships between selected traits (proc corr; SAS Institute 2000) to clarify interactions. These results refer to Spearman rank correlations $\left(\mathrm{r}_{\mathrm{s}}\right)$ due to the parameters' non-normal distribution.

The relationship among all traits was analysed by a Prinicipal Component Analysis (PCA), an unconstrained linear approach. Ordination of individuals was performed with SAS procedures (proc factor and proc princomp) using a data matrix at the population level to elucidate the assignment of provenances to their particular key variables and their potential divergence.

In the PCA, we considered all recorded traits of growth, reproduction and morphology that were also analysed by univariate statistics with the exception of 'Number of racemes 2000', 'p transition bud 1999-fruit 2000', 'Proportion of mature fruits' due to missing values, and variables that are transferable into one another. Thus, the matrix consisted of 36 variables and 18 populations. The resulting coordinates of traits were scaled by a factor of 4 for plotting.

\section{Results}

\section{Biometrical data}

\section{Growth}

Over the total investigation period the invasive Irish populations showed highest values in all growth parameters in all years (Table 2). Increase of shoot length was significantly the largest in Ireland. For example, in 2001 the increase in Ireland was $19.6 \mathrm{~cm}$ compared to $7.1 \mathrm{~cm}$ and $4.6 \mathrm{~cm}$ in Georgia and Spain, respectively. Thus, the increase in shoot length of invasive populations was two to four times higher than in native populations (Fig. 2). Variability within the countries was different: growth values of Spanish populations were consistently low; whereas Georgian increases in shoot length in 2000 ranged from population medians $2.6 \mathrm{~cm}$ to $9.8 \mathrm{~cm}$ and the Irish ones from $9.9 \mathrm{~cm}$ to $30.0 \mathrm{~cm}$. Significant differences between populations were especially found within Irish provenances (Fig. 3). Although the increase in shoot length of most of the Irish populations with a median of $9.6 \mathrm{~cm}$ was significantly higher than that of Spanish and Georgian populations, the Irish population $\mathrm{N}$ did not differ significantly from native populations in 2000. This trend was also observed for population N in 1999 and 2001. 


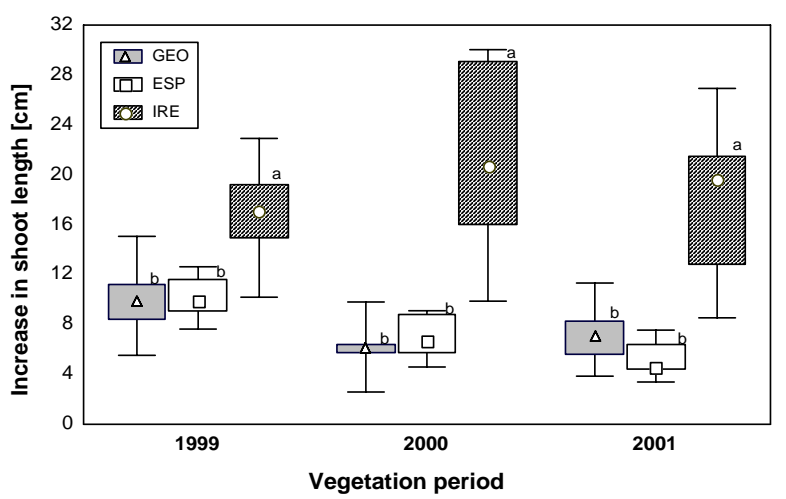

Fig. 2: Absolute increase in shoot length during vegetation periods 1999, 2000, 2001. Medians, quartiles, minimum and maximum refer to population medians $(n=6)$, i. e. the mean of 16 individuals in a population. Different letters indicate significant differences according to the REGWQ-test.

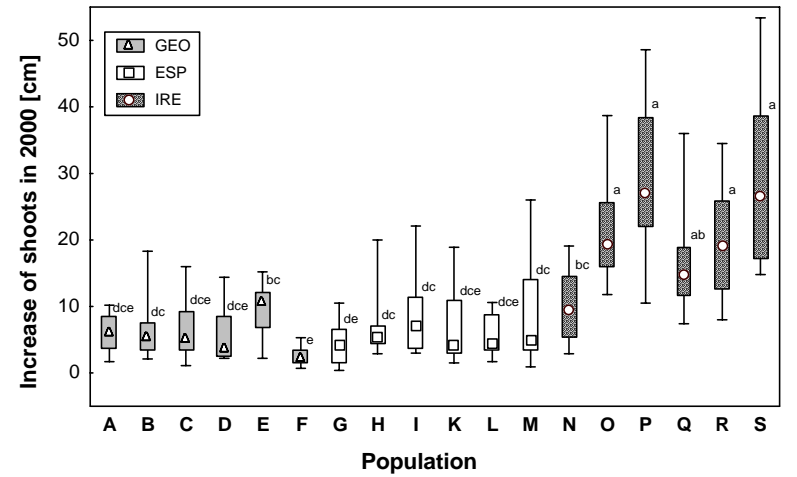

Fig. 3: Absolute increase in shoot length in 2000 on the population level. Values are medians, quartiles, minimum and maximum $(\mathrm{n}=16)$. Different letters indicate significant differences according to the REGWQ-test.

With a median leaf number of 12.0, 15.1 and 14.3 for the subsequent years, the Irish populations produced significantly more leaves than the Spanish and Georgian ones (Fig. 4). Variability was highest within the Irish populations, especially in 2000 and 2001 (minimum and maximum 10.1 19.0 and 9.1 - 19.0). Significant differences were encountered for all recorded growth parameters: with a median of 1.5 branches per sprout in 2000 and 1.2 in 2001 branching occurred more often in Irish populations (Table 2). In a similar manner, the number of internodes per year was significantly higher in the same periods. The median increase in basal diameter over two years was $6.2 \mathrm{~cm}$ in the Irish populations; whereas the native ones reached less than a third of this value.

Life span of leaves showed no significant differences between countries (Table 2), although the probability of leaf transition from 1999 to 2001 just barely failed to be significant: with a median transition probability of 0.8 Georgian leaves tended to have a longer persistency than Irish (0.6) and Spanish (0.5) leaves.

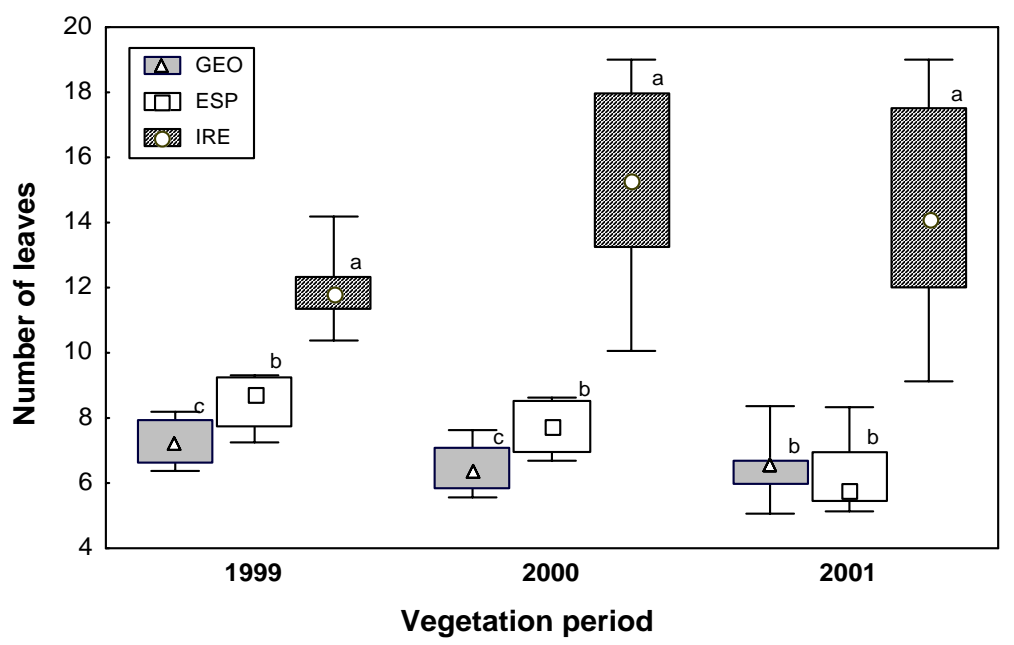

Fig. 4: Absolute increase in number of leaves during vegetation period 1999, 2000, 2001. Medians, quartiles, minimum and maximum refer to population medians $(\mathrm{n}=$ 6 ), i. e. the mean of 16 individuals in a population. Different letters indicate significant differences according to the REGWQ-test. 
Table 2: Growth parameters and leaf morphology. Values are medians of population means $(n=6)$, i. e. the mean of all sampled individuals in a population; $p$ values refer to ANOVA, $* \alpha=0.05 ; * * \alpha=0.01$, *** $\alpha=0.001$, n.s. $=$ not significant; $n=6$ for each provenance. Different letters indicate significant differences according to the REGWQ test. No. refers to labelling of parameters in Fig. 11.

\begin{tabular}{|c|c|c|c|c|c|c|c|}
\hline No. & Variable & d.f. & $\mathbf{F}$ & $\mathbf{p}$ & GEO & ESP & IRE \\
\hline 1 & Increase in shoot length 1999 [cm] & 2 & 7.52 & $0.0055 * \star$ & $9.82^{\mathrm{b}}$ & $9.84^{\mathrm{b}}$ & $17.1^{\mathrm{a}}$ \\
\hline 2 & Increase in shoot length $2000[\mathrm{~cm}]$ & 2 & 25.28 & $<0.0001 * \star *$ & $6.12^{\mathrm{b}}$ & $6.61^{\mathrm{b}}$ & $20.69^{a}$ \\
\hline 3 & Increase in shoot length 2001 [cm] & 2 & 27.00 & $<0.0001 * \star \star$ & $7.14^{b}$ & $4.58^{b}$ & $19.64^{\mathrm{a}}$ \\
\hline 4 & Sum of total increase in shoot length $1999-2001[\mathrm{~cm}]$ & 2 & 14.50 & $0.0003 * \star \star$ & $30.65^{b}$ & $38.89^{b}$ & $124.68^{\mathrm{a}}$ \\
\hline 5 & Number of branchings 2000 & 2 & 8.77 & 0.0030 ** & $0.19^{b}$ & $0.34^{b}$ & $1.47^{\mathrm{a}}$ \\
\hline 6 & Number of branchings 2001 & 2 & 7.30 & 0.0061 ** & $0.47^{b}$ & $0.38^{b}$ & $1.19^{\mathrm{a}}$ \\
\hline 7 & Number of internodes & 2 & 6.28 & $0.0104 *$ & $1.00^{b}$ & $1.00^{b}$ & $1.27^{\mathrm{a}}$ \\
\hline 8 & Leaf number 1999 & 2 & 37.57 & $<0.0001 * * \star$ & $7.19^{c}$ & $8.72^{b}$ & $11.81^{\mathrm{a}}$ \\
\hline 9 & Leaf number 2000 & 2 & 51.08 & $<0.0001 * \star \star$ & $6.38^{c}$ & $7.75^{b}$ & $15.25^{a}$ \\
\hline 10 & Leaf number 2001 & 2 & 30.52 & $<0.0001 * \star *$ & $6.55^{\mathrm{b}}$ & $5.79^{b}$ & $14.13^{\mathrm{a}}$ \\
\hline 11 & Sum of leaf number $1999-2001$ & 2 & 21.16 & $<0.0001 * \star \star$ & $23.75^{b}$ & $30.37^{b}$ & $73.78^{\mathrm{a}}$ \\
\hline \multirow[t]{2}{*}{12} & Increase in basal diameter $\left[\mathrm{mm}^{2}\right.$ years $\left.{ }^{-1}\right]$ & 2 & 12.64 & $0.0006 * \star \star$ & $1.73^{b}$ & $1.43^{b}$ & $6.19^{a}$ \\
\hline & RGR Increase in basal diameter $\left[\mathrm{mm}_{\text {year }}{ }^{-1} \mathrm{~mm}^{-1}\right]$ & 2 & 11.59 & $0.0009 * \star \star$ & $0.04^{b}$ & $0.02^{c}$ & $0.08^{\mathrm{a}}$ \\
\hline 13 & p leaf transition 1999-2001 & 2 & 3.67 & 0.0503 n.s. & 0.83 & 0.50 & 0.55 \\
\hline 14 & p leaf transition 2000-2001 & 2 & 3.18 & 0.0707 n.s. & 0.97 & 0.89 & 0.91 \\
\hline 15 & Maximum age of leaves [years] & 2 & 1.48 & 0.2596 n.s. & 2.13 & 1.89 & 1.87 \\
\hline 16 & Length of leaf [cm] & 2 & 21.29 & $<0.0001 * * *$ & $19.94^{\mathrm{a}}$ & $15.36^{b}$ & $14.99^{b}$ \\
\hline 17 & Width of leaf [cm] & 2 & 38.18 & $<0.0001 * * \star$ & $5.51^{a}$ & $3.92^{b}$ & $3.86^{b}$ \\
\hline 18 & Shape of leaf $\left[\mathrm{cm} \mathrm{cm}^{-1}\right]$ & 2 & 12.39 & $0.0007 * \star \star$ & $0.66^{a}$ & $0.63^{b}$ & $0.64^{b}$ \\
\hline 19 & Leaf area $\left\lceil\mathrm{cm}^{2}\right\rceil$ & 2 & 36.07 & $<0.0001^{\star \star \star}$ & $90.94^{\mathrm{a}}$ & $51.16^{b}$ & $48.84^{b}$ \\
\hline 20 & Length-width ratio $\left[\mathrm{cm} \mathrm{cm}^{-1}\right]$ & 2 & 4.29 & 0.0336 * & $3.69^{b}$ & $3.96^{\mathrm{ab}}$ & $4.05^{a}$ \\
\hline 21 & Maximum leaf area $\left[\mathrm{cm}^{2}\right]$ & 2 & 50.02 & $<0.0001 * \star \star$ & $122.29^{\mathrm{a}}$ & $67.27^{b}$ & $71.47^{b}$ \\
\hline 22 & Maximum length of leaf $[\mathrm{cm}]$ & 2 & 39.31 & $<0.0001^{\star \star \star}$ & $22.90^{\mathrm{a}}$ & $17.57^{\mathrm{b}}$ & $17.99^{b}$ \\
\hline 23 & Maximum width of leaf $[\mathrm{cm}]$ & 2 & 41.19 & $<0.0001^{\star \star \star}$ & $6.65^{\mathrm{a}}$ & $4.83^{b}$ & $4.86^{b}$ \\
\hline
\end{tabular}

\section{Morphology}

Data on leaf morphology revealed clear differences between the Georgian populations and those of other origin (Table 2, Fig. 5): leaves from Georgian rhododendrons reached a median length of 19.9 cm; whereas individuals from Spain and Ireland had significantly shorter leaves with $15.4 \mathrm{~cm}$ and $15.0 \mathrm{~cm}$, respectively. Analogously, Georgian Rhododendron leaves were widest and had both highest median leaf area of $90.9 \mathrm{~cm}^{2}$ and maximum leaf area of $122.3 \mathrm{~cm}^{2}$, based on population medians of the largest leaf of each of the 16 sampled target individuals in a population. Purely morphological traits such as length-width ratio and shape of leaves revealed highly significant differences between Georgian provenances on the one hand, and Spanish and Irish ones on the other hand. The Irish and Spanish Rhododendron leaves were more narrow and straighter. Similarly, the parameter shape, defined as length from leaf base to widest width divided by width, showed a significantly different expression for Georgian leaves compared to Spanish and Irish ones. 

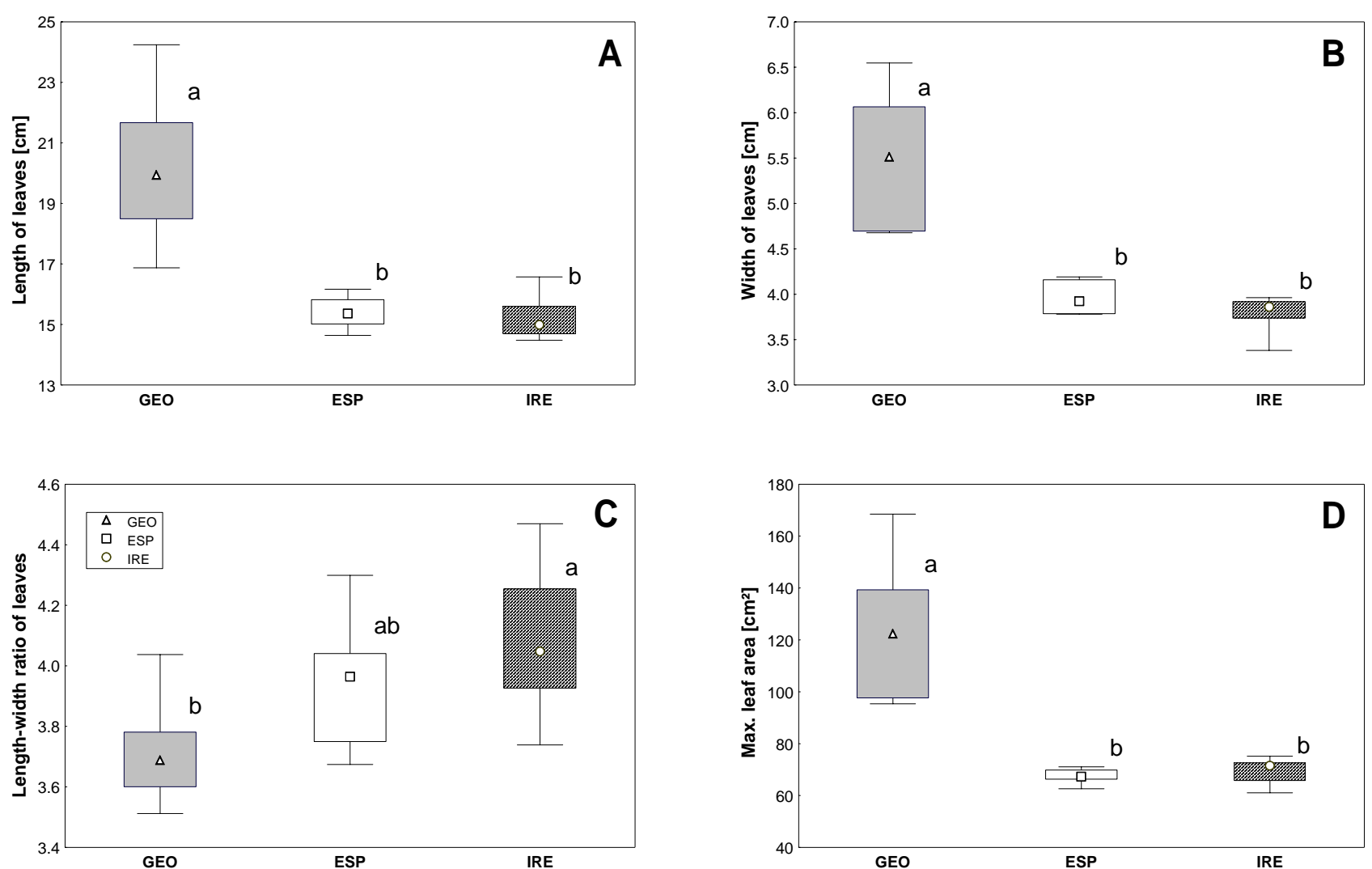

Fig. 5: Leaf characteristics of Georgian, Spanish and Irish populations. A) Absolute length of leaves, B) Absolute width of leaves, C) Length-width ratio of leaves D) Maximum leaf area. Medians, quartiles, minimum and maximum refer to population medians $(n=6)$, i. e. the mean of 16 individuals in a population. Different letters indicate significant differences according to the REGWQ-test.

\section{Population parameters}

\section{Population structure}

The distribution of all target individuals in height classes (Fig. 6) reveals that Spanish populations were dominated by high individuals. The majority of studied Spanish individuals was found to have a height of 2-3 m; whereas most of the Irish individuals belonged to the 1-2 m class. The majority of Georgian individuals were even smaller with highest frequencies in the class up to $1 \mathrm{~m}$. Data on volume and extension of the investigated individuals showed similar trends (Table 3). The calculated mean age of the target individuals was highest in the Spanish populations, where it reached a median of 53 years (minimum 25 years and maximum 85 years). Georgian and Irish target individuals were significantly younger with a median of 22 and 23 years, respectively (Fig. 7). Density of populations, which was calculated from all individuals $>20 \mathrm{~cm}$, showed no significant differences between the countries (Table 3). Although maximum values (5.5 individuals per $\mathrm{m}^{2}$ ) were much higher in Georgian populations, they did not differ significantly from Spanish or from Irish populations. 


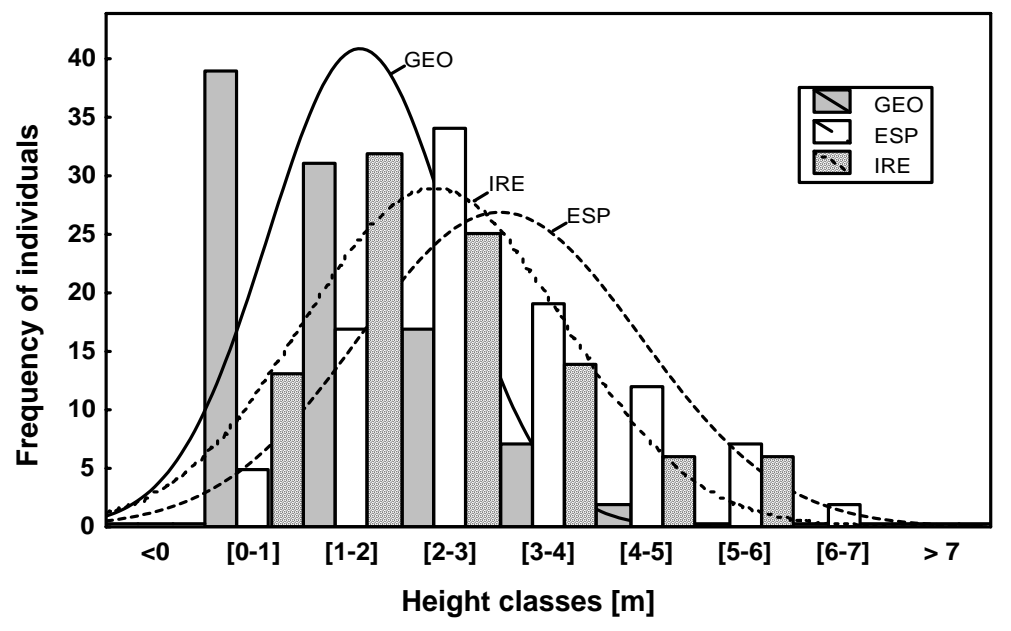

Fig. 6: Frequency distribution of individuals within each country. Values are absolute numbers of individuals in each class ( $n=96$ for each country).

\section{Reproduction}

Regeneration studies showed significant differences in reproduction success with a consistent pattern in both observation periods (Fig. 8). There was no seedling establishment in any of the Georgian populations: whereas rare establishment events were encountered in Spain only in populations $\mathrm{K}$ and $\mathrm{M}$ in the year 2000 (with a median of 2.9 and 0.2 seedlings per $\mathrm{m}^{2}$ ) and in population $\mathrm{K}$ and $\mathrm{L}$ in 2001 (with a median of 2.5 and 0.1 seedlings per $\mathrm{m}^{2}$ ). In contrast, seedling density was much higher in Ireland, with a median of 1.4 and 2.6 seedlings per $\mathrm{m}^{2}$ in 2000 and 2001. Population N was the only Irish site in 2000 where no seedlings were encountered. In 2001, the maximum of seedling density was observed in the Irish population O, with a mean value of 9.9 seedlings per $\mathrm{m}^{2}$.

Table 3: Reproduction characteristics and population traits. Values are medians of population means $(n=6)$, i. e. the mean of all sampled individuals in a population; $p$ values refer to ANOVA (variable indices $1=$ referring to target individuals, $2=$ referring to additional individuals, $3=$ referring to transect squares); $* \alpha=0.05, * * \alpha=0.01$, *** $\alpha=$ 0.001, n.s. $=$ not significant. Different letters indicate significant differences according to the REGWQ test. No. refers to labelling of parameters in Fig. 11.

\begin{tabular}{|c|c|c|c|c|c|c|c|}
\hline No. & Variable & d.f. & $\mathbf{F}$ & $\mathbf{p}$ & GEO & ESP & IRE \\
\hline 24 & Number of generative buds $1999^{1}$ & 2 & 1.55 & 0.2435 n.s. & 1.37 & 1.63 & 5.94 \\
\hline \multirow[t]{4}{*}{25} & Number of racemes $1999^{1}$ & 2 & 0.16 & 0.8503 n.s. & 0.78 & 0.72 & 1.31 \\
\hline & Number of racemes $2000^{1}$ & 2 & 1.86 & 0.2474 n.s. & 1.14 & 1.78 & 4.23 \\
\hline & $\mathrm{p}$ transition bud 1999 -fruit $2000^{1}$ & 2 & 0.14 & 0.8726 n.s. & 0.87 & 0.90 & 0.92 \\
\hline & Proportion of mature fruits ${ }^{1}$ & 2 & 0.08 & 0.9221 n.s. & 0.89 & 0.89 & 0.89 \\
\hline 26 & Ratio p gauze / $p$ reference ${ }^{2}$ & 2 & 1.40 & 0.2781 n.s. & 0.09 & 0.07 & 0.05 \\
\hline 27 & Proportion of clonality [\%] $]^{1}$ & 2 & 22.74 & $<0.0001$ *** & $56.35^{\mathrm{a}}$ & $5.28^{c}$ & $12.95^{\mathrm{b}}$ \\
\hline 28 & Seedlings $2000\left[\mathrm{~m}^{-2}\right]^{1}$ & 2 & 7.36 & 0.0059 ** & $0.00^{\mathrm{b}}$ & $0.00^{b}$ & $1.38^{\mathrm{a}}$ \\
\hline 29 & Saplings $2000\left[\mathrm{~m}^{-2}\right]^{1}$ & 2 & 0.69 & 0.5189 n.s. & 0.09 & 0.00 & 0.09 \\
\hline \multirow[t]{2}{*}{30} & Seedling $2001\left[\mathrm{~m}^{-2}\right]^{1}$ & 2 & 19.66 & $<0.0001$ *** & $0.00^{\mathrm{b}}$ & $0.00^{b}$ & $2.59^{\mathrm{a}}$ \\
\hline & Age transect individual [years] ${ }^{1}$ & 2 & 6.52 & $0.0092^{* *}$ & $12.14^{\mathrm{b}}$ & $23.34^{\mathrm{a}}$ & $16.01^{\mathrm{ab}}$ \\
\hline 31 & Density of individuals $>20 \mathrm{~cm}\left[\mathrm{~m}^{-2}\right]^{1}$ & 2 & 0.70 & 0.5123 n.s. & 2.34 & 1.56 & 1.84 \\
\hline 32 & Extension in direction $1[\mathrm{~m}]^{3}$ & 2 & 8.64 & 0.0032 ** & $1.38^{\mathrm{b}}$ & $2.97^{\mathrm{a}}$ & $2.14^{\mathrm{a}}$ \\
\hline 33 & Extension in direction $2[\mathrm{~m}]^{3}$ & 2 & 9.81 & $0.0019 * *$ & $1.26^{\mathrm{b}}$ & $2.26^{a}$ & $1.83^{\mathrm{a}}$ \\
\hline 34 & Height of target individuals $[\mathrm{m}]^{3}$ & 2 & 12.75 & $0.0006 * * *$ & $1.61^{\mathrm{c}}$ & $2.93^{\mathrm{a}}$ & $2.16^{\mathrm{b}}$ \\
\hline 35 & Volume of target individuals $[\mathrm{m}]^{3}$ & 2 & 10.8 & 0.0012 ** & $2.01 b$ & $20.83^{\mathrm{a}}$ & $6.48^{\mathrm{a}}$ \\
\hline 36 & Age target individuals [years] ${ }^{3}$ & 2 & 15.52 & $0.0002 * * *$ & $21.84^{\mathrm{b}}$ & $53.09^{a}$ & $23.08^{b}$ \\
\hline
\end{tabular}




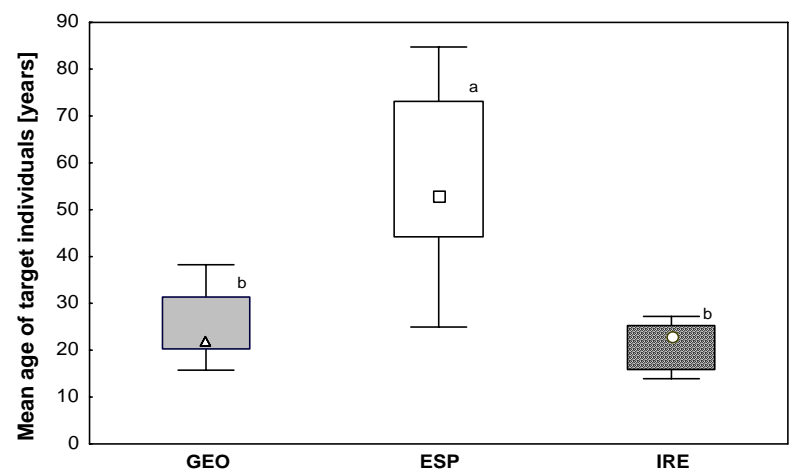

Fig. 7: Calculated mean age of Georgian, Spanish and Irish individuals. Medians, quartiles, minimum and maximum refer to population medians $(n=6)$, i. e. the mean of 16 individuals in a population. Different letters indicate significant differences according to the REGWQ-test.

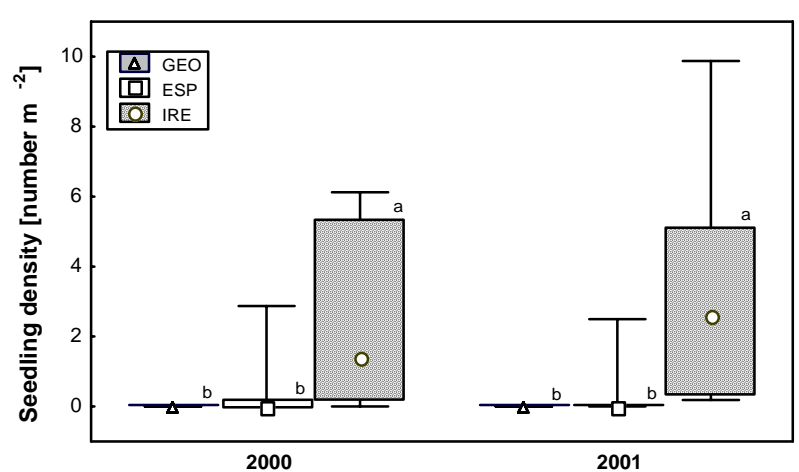

Fig. 8: Seedling density in Georgian, Spanish and Irish populations in 2000 and 2001. Medians, quartiles, minimum and maximum refer to population medians $(n=6)$, i. e. the mean of 16 transect squares in a population. Different letters indicate significant differences according to the REGWQ-test.

We found no significant difference in the number of generative buds in 1999 between the three countries (Fig. 9a, Table 3). However, although not significant, the Irish individuals displayed a trend toward a higher flowering rate. Variability among Irish populations was much higher than in Georgian and Spanish populations with a minimum number of 0.1 buds per individual in population $\mathrm{N}$ and a maximum of 16.5 buds in population Q. The transition probability from buds 1999 to fruits 2000 was the same in all countries (Table 3). In addition, the provenances showed no significant difference in fruit set. Nevertheless, the median number of racemes per individual was higher in Irish populations with a median of 4.2 racemes (and a maximum of 15.9 racemes in population Q) compared to a median of 1.1 and 1.8 racemes per individual in Georgia and Spain (Fig. 9b). The proportion of mature fruits as a measure of fecundity of fruit set was the same in all countries. A median percentage of $89 \%$ of all capsules reached maturity (Table 3).

Gauze bag treatment reduced fruit set to less than 10\% compared to non-bagged fruits (Table 3). The treatment effect was high in all countries, but did not differ significantly between them.
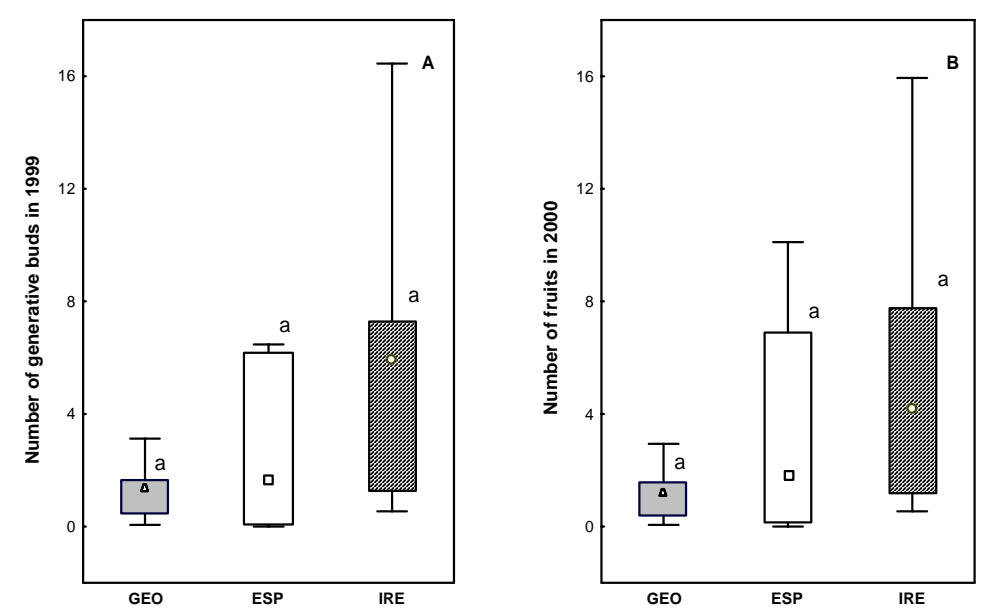

Fig. 9: Absolute numbers of generative buds in 1999 (A) and numbers of succeeding fruits in 2000 (B). Medians, quartiles, minimum and maximum refer to population medians $(n=6)$, i. e. the mean of 16 individuals in a population. Different letters indicate significant differences according to the REGWQ-test. 


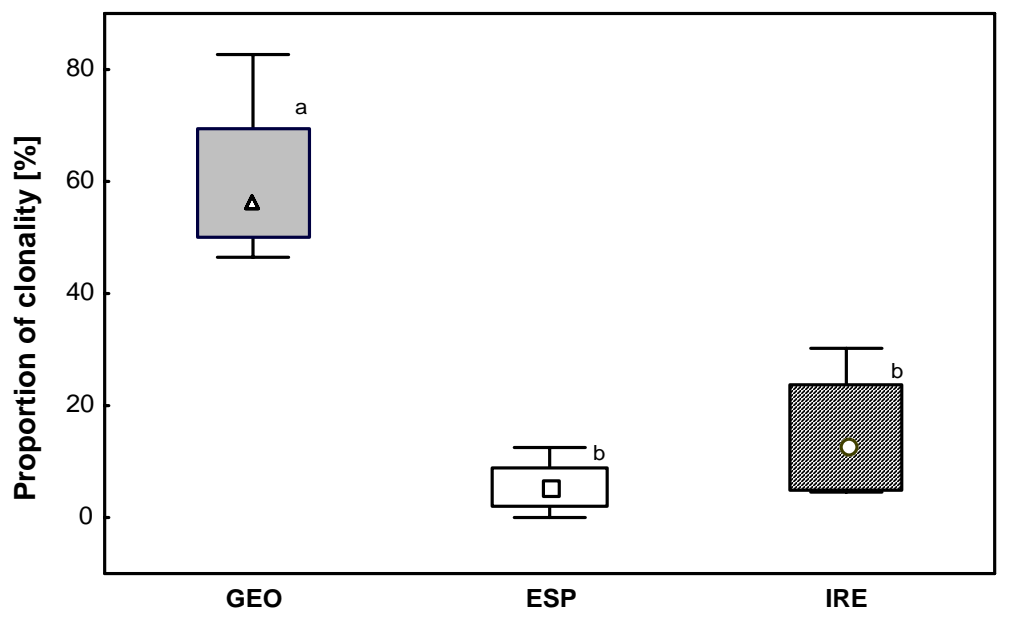

Fig. 10: Proportion of clonality within the countries. Medians, quartiles, minimum and maximum refer to population medians $(n=6)$, i. e. the mean of 16 transect squares in a population. Different letters indicate significant differences according to the REGWQ-test.

The proportion of clonality was significantly different between the countries (Fig. 10): Georgian Rhododendron populations reached a median proportion of clonality of $56 \%$, while only $5 \%$ of the Spanish individuals and 13\% of the Irish individuals showed clonal spread.

\section{Intercorrelation}

PCA revealed a clear pattern for all examined traits (Fig. 11). The first axis explained about 37.2\% of the total variation of the data set and showed a strongly positive correlation with most of the growth traits, such as increase in shoot length (nos.1 - 4 in Fig. 10), number of leaves (nos. 8 - 11), number of branching (nos. 5 - 6) and number of internodes (no. 7). The traits of leaf morphology

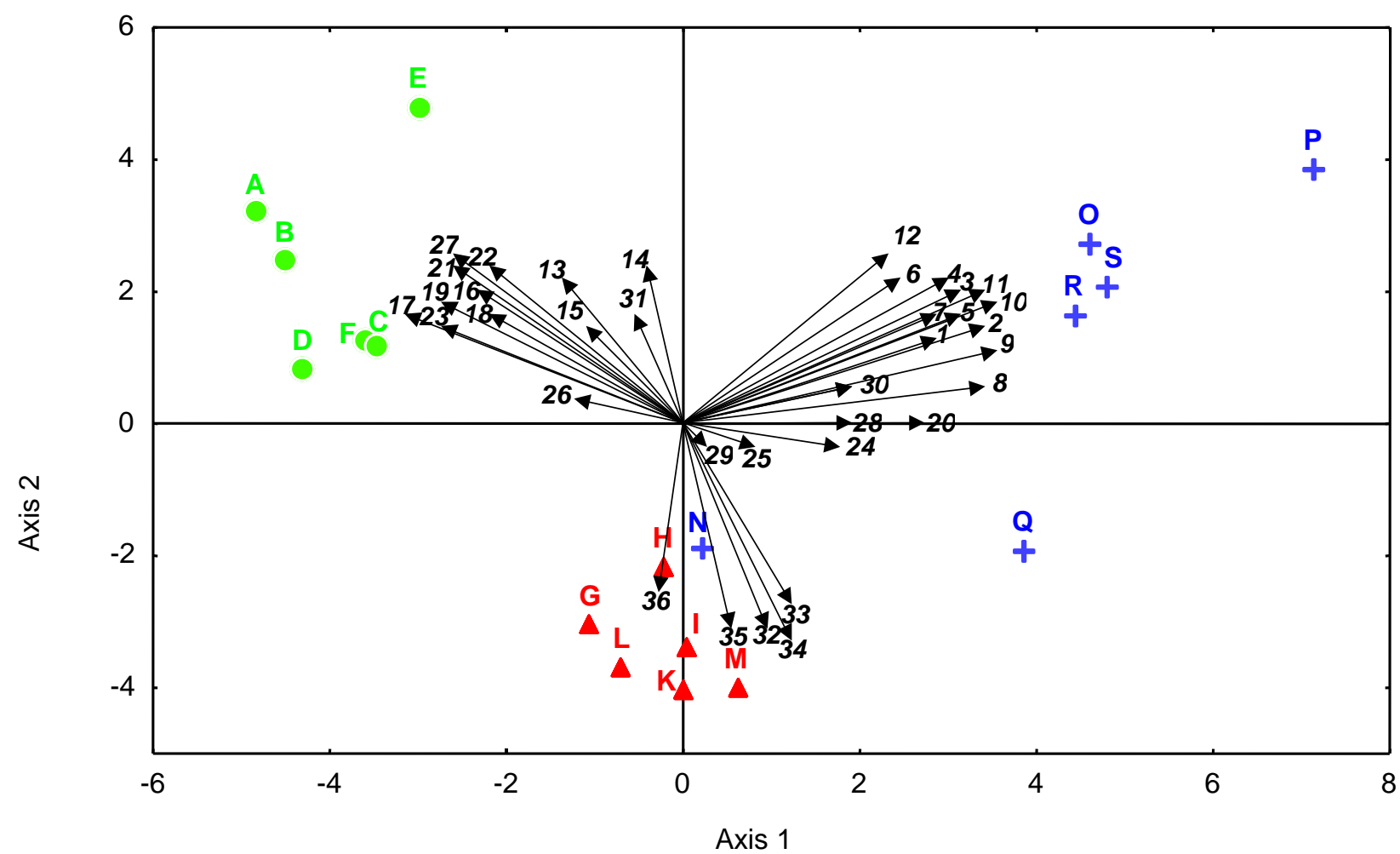

Fig. 11: PCA ordination diagram of 1st and 2nd axis. Letters refer to population indices (A-F: Georgian populations, GM: Spanish populations, N-S: Irish populations). Numbers and arrows refer to recorded variables. 


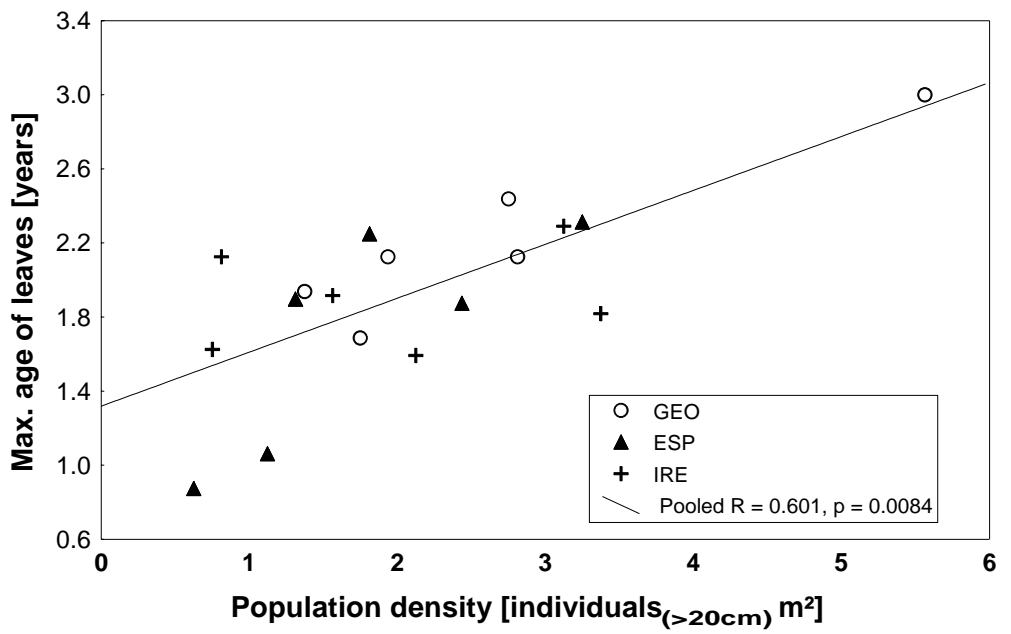

Fig. 12: The relationship between age of leaves based on the mean of 16 individuals in a population and population density assessed by 16 transect squares in a population.

(nos. 16 - 23) and leaf age (nos. 13 - 15) were negatively correlated with axis 1 . The second axis explained about $24.6 \%$ of total variance and was closely correlated with size traits. A third axis still explained a further $10.9 \%$ of the total variance and was related to traits of reproduction, such as numbers of buds, fruits, seedlings and saplings (nos. 24 - 26, 28 - 30). The populations of all origins were clearly assigned to specific key factors. Georgian populations were closely associated with leaf traits; whereas discrimination of Irish populations was mainly due to their growth rates. The Spanish and also the Irish populations $\mathrm{N}$ and Q were characterised by size traits. The latter two Irish populations deviated from the rest; i. e. they were more closely correlated with Spanish populations than with Irish ones.

Leaf age was positively related to population density when based on the pooled data of the three countries (Fig. 12). Leaf persistence increased significantly with density of individuals above $20 \mathrm{~cm}$. The correlation was also significant when based only on Georgian $\left(\mathrm{r}_{\mathrm{s}}=0.841, \mathrm{p}=0.036\right)$ and Spanish $\left(r_{s}=0.829, p=0.0416\right)$ populations, but was not for Irish ones $\left(r_{s}=0.787, p=0.1429\right)$. Leaf area and number of leaves were negatively correlated in the pooled data set (Fig. 13a). However, this relationship was due to differences between countries. Georgian plants had few
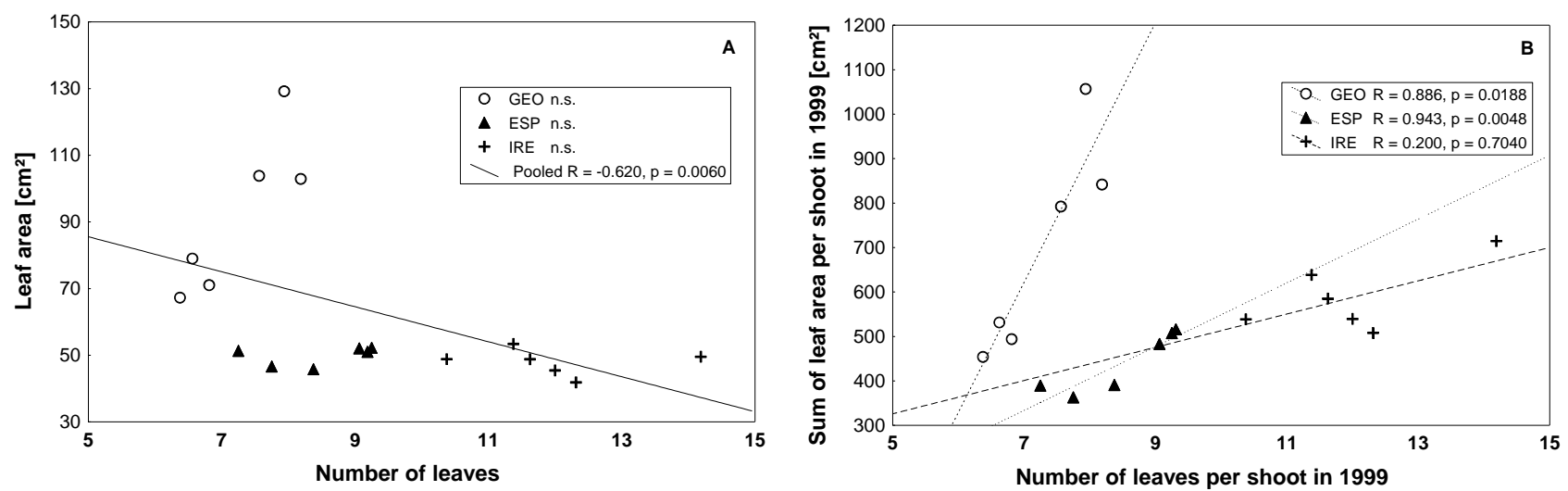

Fig. 13: The relationship between A) leaf area and number of leaves and B) sum of leaf area per shoot in 1999 and number of leaves in 1999. Each value is based on the mean of 16 individuals in a population. 
leaves but at the same time large specific leaf areas. In contrast, the median leaf area was smaller in the Spanish and Irish populations; whereas the number of leaves was higher. Total leaf area per marked shoot in 1999 was positively correlated with the number of leaves in Georgian and Spanish populations but not in the Irish ones (Fig. 13b). Although Irish and Spanish rhododendrons did not differ from each other in median leaf area (Table 2), the Irish plants had a larger total leaf area per marked shoot (Fig. 13b). This larger leaf area was attained by a larger number of leaves per shoot. Neither the Irish nor the Spanish individuals achieved full compensation for smaller leaf areas compared to Georgian individuals, but compared to Spanish rhododendrons, the Irish ones managed to make up for losses to a higher degree.

\section{Discussion}

The three provenances of Rhododendron ponticum were clearly differentiated with respect to morphological and plant ecological characteristics. According to Baker (1974), rapid growth, high seed production, vigorous vegetative reproduction and competitiveness, in particular, can be expected to be of importance for an invasive species. At first glance, these assumptions seem to apply for Rhododendron ponticum in general. However, we clearly showed that some factor groups of invasive traits were explicitly connected to Irish Rhododendron, whereas others were not.

A larger size, which is often mentioned as an attribute of invaders (Crawley 1987; Blossey \& Nötzold 1995), was associated with Spanish rhododendron, rather than with the invasive Irish ones. Spanish populations are striking for their high fraction of king-sized and comparably old individuals. Thus, the generalisation that more species are larger as aliens than as natives (Crawley 1987) cannot be confirmed. Recent studies contend that these summarising observations do not comply with essential requirements of comparability and, thus, reject any generalisation for reasons of sampling bias (Simons 2003). Thébaud \& Simberloff (2001) also refused any generalised assumption of increased height in invasive plants in their introduced range. They utilised the Flora Europaea data, as did Crawley (1987), supplemented by California and Carolina records to perform reciprocal comparisons. The former authors compared floras of native and introduced range and looked for tendencies of plants to be taller in some particular region, no matter what their origin, and demonstrated that, apart from an origin effect, an effect of destination, i. e. of habitat, applied, too. It is possible that, in the present study, the restriction to populations at forest sites in all countries might have influenced the results of plant size, since many rhododendron in Ireland can be found in open areas, where they attain larger sizes than those recorded in the present study. Ultimately, this matter can only be answered by reciprocal transplant experiments (Bruelheide 1999; Willis et al. 2000). 
Another factor associated with invasiveness is clonal spreading. However, this characteristic was typical for Georgian rather than Irish populations. Pornon et al. (2000) could demonstrate that layering is only weakly developed or absent in younger populations but extensively developed in closed and mature ones in Rhododendron ferrugineum. Although we did not find high proportions of clonality for Spanish populations, Mejías et al. (2002) reported that in many cases excavation revealed a layering origin from a bigger plant. These authors discuss the meaning of a variable balance between sexual reproduction and vegetative multiplication depending on environmental condition. However, although vegetative propagation was encountered in single Irish populations, clonality does not seem to be a prominent factor in invasiveness of Rhododendron ponticum in Ireland.

The results confirmed our first hypothesis that Irish populations show higher growth rates than native ones. Since the high growth rates are the most prominent feature of the Irish populations, they are quite probably the decisive factory to explaining the invasion success of Rhododendron ponticum. They might be genetically or environmentally determined. For example, in greenhouse experiments Lythrum salicaria shows a better growth in introduced populations from North America than in native ones from Europe and Asia (Bastlová \& Kvet 2002). Willis et al. (1999) documented higher plant growth for non-indigenous genotypes of Lythrum salicaria from Australia and the USA compared to indigenous ones, although these differences were not significant. Greenhouse experiments with different $R$. ponticum origins also confirmed highest growth rates for the Irish populations (unpublished data). In contrast, a common garden experiment with native and invasive provenances of Carduus nutans, Digitalis purpurea, Echium vulgare and Senecio jacobaea provided only little support for a genetically determined trait, but supported the hypothesis of a response to benign environmental conditions in the new area of introduction (Willis et al. 2000).

It is probable that both concepts apply for Rhododendron ponticum. Depending on whether invasive Irish and Georgian or Irish and Spanish populations are compared, the differences seem to have either a genetical or an environmental explanation. With respect to, most probably, genetically fixed traits, i. e. of leaf morphology, the Irish individuals differ from Georgian ones, but show high similarity to Spanish rhododendrons. These results agree with the finding that invasive British populations have mainly originated from Spanish populations (Milne \& Abbott 2000). Thus, the differences in leaf morphology, which ascribe large and persistent leaves to Georgian populations, are probably due to taxonomical separation of the two subspecies.

Shorter-lived leaves might be associated with lower construction costs in Irish rhododendron. Nagel \& Griffin (2001) reported lower area-based leaf construction cost values for invasive Lythrum salicaria plants compared to five co-occurring herbaceous plants and shrubs. They suggested that 
the production of more photosynthetic leaf surface area with lower energy expense, resulting from either lower requirements or higher energy efficiency, would help to outcompete neighbouring native species. These results agree with those obtained in the study of Baruch \& Goldstein (1999). In a comparative investigation between native and invasive species in Hawaii, the authors showed that invasive plants had a higher specific leaf area and lower construction cost than native ones. The authors ascribe this to a generally more efficient use of resources combined with higher growth rates of invasive species. Nevertheless, a less costly leaf construction compared to Georgian individuals applies similarly to Spanish ones and, thus, does not explain why Spanish rhododendron are less invasive than Irish ones. The obvious answer can only be that Spanish populations are climatically constrained. The fact that Irish rhododendron have profited from a release from climatic restrictions is expressed, on the one hand, by rapid and high growth, and on the other hand by only brief interruption during winter periods as seen by the recorded numbers of internodes in Irish populations. For Irish sites in general, two to three periods of stem elongation are mentioned, in May-June and July-August, a third period may occur in September and a few buds might already open in February (Cross 1975). The pattern of range expansion also supports this view since the spread of invasive rhododendron in their new range mainly concentrates on the West coasts of Ireland and Britain, thus, apparently profiting from climatically suitable conditions (Usher 1986). Additionally, the hypothesis that a release from climatic constraints is effective was also supported by own observations: Spanish rhododendron individuals once transplanted to an Irish forest site developed well under local conditions (unpublished data).

Environmental conditions, in general, also seem to be of vital importance for the second key factor of Irish populations, i. e. reproduction. Sexual reproduction was limited in both native origins but was high in Ireland, this confirming our second hypothesis. Reduced fruit set seems to be less important in a natural setting. Similarly, reduced germination capacity is also of little import, as laboratory experiments have shown (personal observations). In contrast, failure of seedling establishment seems to be crucial. These findings agree with the results of Mejías et al. (2002), who studied population structure and reproduction patterns in 20 sampled Rhododendron populations in Southern Spain. Some of their populations are identical to our own study sites (G, H, K, L). Mejías et al. (2002) concluded that in spite of relatively high fruiting rates, recruitment in Spanish populations is low and depends on the availability of safe sites. Cross (1975) found similar requirements for successful recruitment in Ireland, but Irish sites offer a higher number of suitable sites that shield seedlings from drought. The occurrence of safe sites in Spain is closely restricted to the contact zone of the rivers, where humid soils and bryophyte carpets can be found (Mejías et al. 2002). We can also confirm this by additional observations in two Spanish populations (I and K) along the waterline, where seedling densities of 0.1 and 7.1 seedlings per $\mathrm{m}^{2}$ were encountered in 
2000 (personal observation). Mejías et al. (2002), thus, hypothesized, that the main invasion process in invaded Western European areas occurs by effective seedling recruitment. The actual findings are in accordance with the results of Grigulis et al. (2001). The authors studied demographic parameters in the life cycle of Echium plantagineum both in its native area in Mediterranean Europe as well as in invaded ranges in Australia. They found seedling establishment in Australia that is five times greater than in native habitats; whereas the proportion of seed bank loss during the germination period was similar between both sites, thus, indicating a lower number of safe sites for seedling establishment in the species' native range.

Despite the findings of a clear trait complex promoting invasiveness in Irish populations, the large variation in these traits among Irish populations should not be ignored. In the area of introduction, the performance of individuals (and populations) with respect to growth and seedling establishment varied to a much higher degree than in the species’ native area. Not all Irish populations showed the observed key factors to the same degree, i. e. some were more similar to Spanish populations. Whether these circumstances are caused by a corresponding variability of habitat specifics or whether they are the result of different genotypes cannot be assessed by observational studies. Growth experiments with populations from all provenances under controlled conditions and profound analyses of site conditions to correlate seedling establishment with environmental characteristics are necessary to distinguish between specific invasive traits and a pure habitat effect or even genotype-environment interactions.

In any case, we can draw the conclusion that growth rates and seedling recruitment, in particular, affect the invasion success of Rhododendron ponticum in the British Isles, and that both, genotype and environment, have a strong impact on this process.

\section{Acknowledgements}

We gratefully acknowledge the assistance of G. Nakhutsrishvili from the Georgian Academy of Science, Tbilisi, and Z. Manvelidze from the Botanical Garden, Batumi, for their help in locating appropriate plots and for organizing the field work in Georgia. Selection of study sites and realisation in Spain was possible due to the friendly and helpful support by J. Arroyo and A. Hampe, Universidad de Sevilla. We thank F. Oliveros for kindly granting us permission to work in the Los Alconorcales Natural Park. We are indebted to G. Doyle, University College Dublin, and the staff from Killarney National Park and Wicklow National Park for realisation of field work in Ireland. We thank M. Wegner, A. Neugebauer, C. Benze and S. Bruns for their assistance in data collection in the field. C. Kluth and M. Wegner provided valuable statistical support and S. Kluth contributed with helpful comments. The project was supported by a grant of the German Research Foundation DFG (BR 1698/3). 



\title{
Invasibility or invasiveness? Effects of habitat, genotype, and their interaction on invasive Rhododendron ponticum (Ericaceae) in the British Isles
}

\begin{abstract}
Biotic invasions are affected either by the invaders' genotypes, by the suitability of the new habitat or by specific genotype-habitat interactions expressed in local adaptations. The relevance of these factors was assessed for the invasive evergreen shrub Rhododendron ponticum. The species originates from the Mediterranean and Black Sea area and has been introduced to the British Isles many times for horticultural reasons, where it has become a successful invader.

Habitat analyses with respect to soil characteristics, climate and community properties were performed in six native populations in both Georgia and Spain and in six invasive ones in Ireland. Growth parameters of marked rhododendron individuals and seedling occurrences in the field were monitored over two years and served as response variables. To assess the impact of local adaptation, we performed a reciprocal transplant experiment with rhododendron cuttings and determined survival and parameters of vegetative increase after one year of growth in all countries. Irish sites showed a significantly higher nutrient supply than the Spanish and Georgian sites. We found strong positive correlations of contents of exchangeable magnesium and potassium and of organic carbon in the soils with growth parameters of shoots and seedling density. The strongest negative correlations were detected for temperature parameters, particularly for seasonal temperature amplitude.

We found origin, target site and interaction effects to be significant in the survival of transplanted rhododendron. The Irish site was the most favourable one across all genotypes, but we found no clear evidence for the existence of generally superior invasive genotypes. Morphological and growth parameters of transplants in Ireland showed a high similarity between Spanish and Irish genotypes. The total increase in shoot length was the highest in Irish genotypes, which suggests that Irish rhododendrons were best adapted to their new area.

The present results confirm that all three factors habitat, genotype and adaptation contribute to the invasion success of Rhododendron ponticum in Ireland. Among these factors, the favourable edaphic and climatic conditions in the new habitat seem to exert the highest influence; this suggests that the invasibility of the new habitat is a key factor for rhododendron invasion.
\end{abstract}

Keywords: biometry, invasive traits, local adaptation, release hypothesis, resource availability, transplantation experiment 


\section{Introduction}

Studies on invasion biology have become a major concern of ecological research since many successful invaders have proven to be a profound threat to natural ecosystems (Vitousek et al. 1996; Williamson 1999; Weber 2003). Concepts for explaining plant invasions are based on different viewpoints. Questions on invasion biology frequently ask whether specific attributes make a species invasive (Gray 1986; Barrett \& Richardson 1986; Rejmánek 1995; Williamson \& Fitter 1996). In this connection, a number of characteristics, e.g. rapid growth rates or high seed set, are likely to be associated with invasive plants (Baker \& Stebbins 1965; Myers \& Bazely 2003). Similarly, the invasibility of ecosystems, in turn, is also broadly accepted as being a suitable approach for studying invasion processes (Crawley 1987; Noble 1989).

In this context, issues of invasion ecology are often discussed as topics in community ecology, since it is likely that some communities are more invasible than others (Crawley 1987; Williamson 1996; Lonsdale 1999). Shea \& Chesson (2002) recently defined the concept of niche opportunity as 'the potential provided by a given community for alien organisms to have a positive rate of increase from low density'. They propose that this opportunity is mainly provided either by resources, lack of natural enemies, the physical environment, in particular climatic conditions, or some favourable combinations of some of these factors. A high resource availability in a new territory might arise from reduced competition effects resulting from the presence of competitively inferior plants in the new community (Callaway \& Aschehough 2000; Alpert et al. 2000), but can also be a specific attribute of the new area such as unused resources, thus, offering a release from previous constraints (Crawley 1987; Davis et al. 2000). There are numerous examples providing evidence that an increase in nutrient availability enhances the invasion success of a plant species; this has been either experimentally tested in the greenhouse or in fertilized plots, or shown by field correlations (Huenneke et al. 1990; Li \& Norland 2001; Hoopes \& Hall 2002). In any case, most studies on invasion processes lack a real comparison of the nutrient supply in habitats of native vs. invasive populations.

Other constraints on plant species' distribution might be due to climatic factors (Woodward 1987). Consequently, invasibility might also be enhanced by the new region's climate. The fact that the invasion patterns of particular taxa correspond well to the climatic conditions in the regions of the taxa's natural distribution has been clearly documented. This is shown, for example, for the biennial Oenothera taxa of North American origin (Mihulka \& Pyšek 2001), whose spread in Central Europe is mainly driven by the existence of lower temperatures and balanced monthly precipitation in their new habitats. Similarly, for Fallopia japonica, Beerling et al. (1995) suggested that its 
invasive occurrences are climatically determined by the mean temperature of the coldest month and the annual heat sum. The climatic regime can therefore be range limiting (Woodward 1987; Beerling 1993; Bruelheide 1999; Schulz \& Bruelheide 1999; Willis \& Hulme 2002), but can also favour spreading once a species has reached a territory that had been hitherto geographically out of reach, but nonetheless consistent with the species’ potential range (Jäger 1988).

The assumed plausible hypothesis of identifying a region's potential invaders by utilising the climate prediction approach fails to yield perfect matches, since both environmental and genetic factors can affect the establishment of a plant into a new community (Clay \& Levin 1986). Moreover, specific habitat-plant interactions between invader and area of introduction affect the invasion success of a species and need to be taken into consideration (Thompson et al. 1995; Mack 1996; Williamson 1999; Radford \& Cousens 2000; Alpert et al. 2000; Klironomos 2002). Rapid evolution as the result of a time lag after a species' introduction can lead to specific local adaptations and might thus give rise to a subsequent successful invasion (Rice \& Mack 1991; Kowarik 1995; Thompson 1998; Mack et al. 2000; Hufford \& Mazer 2003). However, Parker et al. (2003) recently reviewed the two mechanisms influencing invasion success, i.e. the general-purpose genotype versus rapid adaptation. The authors stress that, thus far, no consensus has been achieved on the contribution of specific local adaptations of single characteristics to a successful invasion. Furthermore, they emphasize that local adaptation, e.g. the assessment of whether invasive populations are best adapted to the invaded habitats, is only detectable by means of reciprocal transplant experiments.

The objective of this study is to compare the role of favourable environmental conditions in the new home range versus local adaptation for Rhododendron ponticum L. Rhododendron ponticum (Ericaceae) is an alien, widely naturalized and invasive species in the British Isles and in the Western part of the European continent, e.g. Belgium and the Netherlands, where it is currently considered a forest weed and, thus, a threat to local biodiversity. The species has been repeatedly introduced to Great Britain since 1763 from the Iberian Peninsula and from the Black Sea area (Elton 1958; Cronk \& Fuller 1995), but it is still not clear when invasive spread actually began.

The successful spread of $R$. ponticum has often been attributed to both the climatic matching hypothesis, i.e. in a broader sense, to a more suitable environment in the new area (Shaw 1984; Mejías et al. 2002), and to specific invasive traits, thus to the concept of an invasive genotype (Cross 1981; Erfmeier \& Bruelheide 2004a). It is suggested, that the combination of mild temperatures with comparatively high precipitation in the British Isles enhances the suitability of the new area for rhododendron invasion. 
Therefore, we intend to characterize the species' habitat both in its native and in its invasive range in terms of climatic and edaphic conditions and to evaluate the extent to which native and invasive populations of different origins differ in their growth and regeneration responses to different environments in the field. This correlative approach is then complemented by reciprocal transplant experiments to estimate the impact of local adaptation for the invasion success of Rhododendron ponticum. We hypothesize that i) the physical and ecological characteristics in invaded habitats are more favourable in terms of a higher resource availability and a more favourable climate than in natural habitats, ii) across different habitats the invasive genotypes are more successful in their responses to growth parameters than the respective native genotypes, and iii) habitat-genotype interactions are involved in the species' invasiveness with the result that invasive populations are best adapted to the invaded habitats.

\section{Methods}

\section{Study species}

Rhododendron ponticum L. is an evergreen Ericaceae shrub assigned to the Pontica series within the genus. Formerly widely distributed throughout Europe during the Tertiary, the species now naturally occurs with a disjunct distribution along the Black Sea coast, in Lebanon and on the Iberian Peninsula (see map in Erfmeier \& Bruelheide 2004a). According to the species' geographical distribution, taxonomic differentiation assigns Spanish and Portuguese plants to the subspecies baeticum; whereas plants from the Black Sea region are recognized as Rhododendron ponticum ssp. ponticum. Rhododendron ponticum reproduces mainly by numerous small winddispersed seeds, but propagation by clonal spreading is also reported (Mejías et al. 2002).

The species occurs primarily on siliceous substrates of low pH. In the Black Sea region it occurs mainly in Fagus orientalis or mixed deciduous forests. On the Iberian Peninsula, Rhododendron ponticum stands are mostly restricted to granite slopes covered with scrub and wooded valleys along small rivers. The altitudinal distribution extends across a wide range from sea level up to the timberline (1900 m a.s.l.) in Turkey and the Caucasus region; whereas, in Southern Spain, rhododendron stands can be found between 400 and $1200 \mathrm{~m}$ a.s.l. The Iberian occurrences comprise the largest endangered Western Mediterranean populations of Rhododendron ponticum (Blanca et al. 2000; Mejías et al. 2002).

In the British Isles, Rhododendron ponticum has naturalized in woods as well as in heaths and bogs, on sandy and peaty soils forming both, dominant stands in the shrub layer of forests or dense thickets in open areas. The species' range expansion in temperate Atlantic Western Europe, yet, is 
Table 1: Climatic parameters of relevant weather stations as long term means (according to Müller 1996).

\begin{tabular}{|c|c|c|c|c|c|c|}
\hline & & $\begin{array}{c}\text { Annual mean } \\
\text { temperature } \\
{\left[{ }^{\circ} \mathrm{C}\right]}\end{array}$ & $\begin{array}{c}\text { Absolute max. } \\
\text { temperature } \\
{\left[{ }^{\circ} \mathrm{C}\right]}\end{array}$ & $\begin{array}{c}\text { Absolute min. } \\
\text { temperature } \\
{\left[{ }^{\circ} \mathrm{C}\right]}\end{array}$ & $\begin{array}{c}\text { Relative } \\
\text { humidity } \\
{[\%]}\end{array}$ & $\begin{array}{c}\text { Precipitation } \\
{[\mathrm{mm}]}\end{array}$ \\
\hline Soci & Russia & 14.0 & 38.0 & -14.0 & 69.0 & 1356 \\
\hline Kutaisi & Georgia & 14.4 & 40.0 & -17.0 & 73.0 & 1333 \\
\hline Cádiz & Spain & 18.3 & 38.0 & -1.0 & 75.0 & 641 \\
\hline Cork & Ireland & 10.4 & 29.4 & -7.2 & 80.0 & 1048 \\
\hline Valentia & Ireland & 10.8 & 29.8 & -9.7 & 85.0 & 1400 \\
\hline
\end{tabular}

an ongoing process, since further occurrences of Rhododendron ponticum have been recently reported from the continent, i.e. in the Netherlands, in Belgium, France and Northwest Germany (Niinemets et al. 2003, personal observations). The sites of natural rhododendron distribution share certain climatic parameters, in particular, high summer temperatures (Table 1), but they also differ remarkably in some other aspects, e.g., in summer precipitation. In contrast, the invaded areas in the British Isles are characterized by lower annual mean temperatures, low summer maximum temperatures, high humidity as well as high and evenly distributed precipitation (Table 1).

\section{Sampling design and habitat characteristics}

In Georgia, Spain and Ireland, six populations of Rhododendron ponticum were selected randomly with the intention of including the maximum altitudinal and geographical range of the species' occurrence in each country. In all three countries, the selection of populations was restricted to forest sites to ensure comparability between the three provenances. Similarly, all the study sites exhibited a northern aspect with a slope of $10^{\circ}$ to $20^{\circ}$. In each population, a study site was established with a size of $16 \mathrm{~m} * 16 \mathrm{~m}$ and a mesh width of $4 \mathrm{~m}$ in the winter of 1999/2000. The closest individual to each of the 16 grid points was chosen for biometrical measurements that were repeatedly performed in summer 2000 and 2001. For further details see Erfmeier \& Bruelheide (2004a).

\section{Predictor variables}

Parameters of edaphic conditions, community properties and microclimate were considered as predictor variables and recorded on different spatial scales, at the individual and population levels with different resolution.

Soil sampling was carried out once in a pit in the centre of each population in the winter of 1999/2000. Soil samples were taken from the uppermost soil layer at a standardized depth of $2 \mathrm{~cm}$. Soil pH was determined for the topsoil. Exchangeable $\mathrm{Ca}, \mathrm{Mg}, \mathrm{K}, \mathrm{Fe}, \mathrm{Mn}$ and $\mathrm{Al}$ were extracted by percolation with $0.2 \mathrm{~N} \mathrm{BaCl}_{2}$ and subsequently analysed by atomic absorption spectrophotometry 
(Spectr. AA-30. Varian). Total carbon and nitrogen were determined with a nitrogen analyser (NA 1500 Carlo Erba Strumentazione). Parameters of community properties, i.e. the species number and canopy cover were determined at each study site. One of the 16 individuals per population was chosen randomly for continuous logging of air temperature from the winter of 1999/2000 to the summer of 2001. Each thermistor probe (Tinytag Plus, Miniature Data logger, Gemini Data Loggers Ltd.) was attached to the last internode of the highest shoot for taking temperature measurements in one-minute intervals for 18 months. The probe was fixed at a height that corresponded to the respective height of the rhododendron shrub layer, thus, in Georgia this height ranged from 0.9 to $3.2 \mathrm{~m}$, in Spain, where the mean age and the size of encountered individuals was generally larger (Erfmeier \& Bruelheide 2004a), i.e. from 2.8 to $4.3 \mathrm{~m}$ and in Ireland it ranged from 1.9 to $3.3 \mathrm{~m}$. The measured temperatures thus referred to the effective air temperature prevailing at the top of the rhododendron shrub layer. On the basis of the overlapping data collection period in all three countries from 01-04-2000 to 31-03-2001, we calculated the number of frost days, the seasonal temperature amplitude (based on monthly means derived from daily means), the annual coldness sum as cumulated temperature below $0^{\circ} \mathrm{C}$ and the annual heat sum as cumulated temperature above $5^{\circ} \mathrm{C}$, both given as degree days. Additionally, the winter heat sum was assessed for the period from 01-10-2000 to 31-03-2001. All heat sums were calculated according to Tuhkanen (1980).

In the summer of 2000, the relative light intensity was determined for each of the 16 target individuals. We used a two-channel Li-COR data logger (LI-1000) with PAR quantum sensors. One of the two sensors was used for logging reference data of $100 \%$ light outside the forests in canopyfree areas. The second sensor measured light intensity at the top of each rhododendron target individual.

Populations D (Georgia), L (Spain) and O (Ireland) were additionally supplied with a weather station (Campbell Scientific Ltd.) to register the effective air temperature at two different heights $(0.05$ and $3.20 \mathrm{~m})$, the effective soil temperature of the topsoil $(-1 \mathrm{~cm})$, PAR $(2.60 \mathrm{~m})$, and soil moisture (-5 cm) using Time Domain Reflectrometry (TDR), continuously from winter 1999/2000 until summer 2001. Temperature and light values were logged at intervals of one hour, TDR logging occurred every four hours.

\section{Response variables}

We considered those characteristics that proved to be the key factors for the invasion success of Rhododendron ponticum - i.e. growth rates and seedling recruitment in particular (see Erfmeier \& Bruelheide 2004a) — to be a measure of the plant's response to the assigned predictor variables. Increase in shoot length and number of leaves were recorded on marked shoots for the vegetation periods 1999, 2000 and 2001 for all 16 target individuals. Measurements of growth parameters 
began from December 1999 to February 2000 and were repeated in the summer of 2000 (July to September) and in the summer of 2001 (August to October). For each population, regeneration success was estimated by counting seedling emergence in $161 \mathrm{~m}^{2}$-subplots along a diagonal transect within each study site, in the summers of 2000 and 2001.

\section{Reciprocal transplant experiment}

In the autumn/winter of 1999/2000, cuttings of Rhododendron branches were collected randomly from different individuals in each of the six populations per country. Harvesting occurred in different months according to the authors' presence in the countries: in November 1999 in Georgia, in January 2000 in Spain, and in February 2000 in Ireland. All cuttings were brought into the greenhouse in Goettingen, Germany, where they were planted onto breeding boards to re-grow roots. After successful rooting, well-developed individuals were chosen for transplanting into the three countries.

In each country, a representative transplantation plot with a size of $300 \mathrm{~cm}$ x $210 \mathrm{~cm}$ was set up in one of its six populations (D, L, O) for this experiment. Three individuals of each population and each country, i.e. a total of 54 individuals (= $3 \times 6 \times 3$ ), were planted in each of the three plots in the target countries. Pre-transplantation rooting success of the plants was estimated in $\mathrm{cm}^{3}$. The plants were randomly positioned in one block at intervals of $30 \mathrm{~cm}$. The plots in Spain and Ireland were fenced to exclude animals, mainly, deer, wild pigs and boars. The Georgian plot was located within the very ample natural rhododendron stand in the Botanical Garden, and, thus, protected against animal induced disturbances. All plots were located in direct proximity to one of our weather stations. The experimental plots were prepared by removing all plants from the herb and shrub layer. The litter layer remained untouched. The plants were brought out in July, August and September 2000 to Georgia, Ireland and Spain, respectively, and monitored, once, from August to October 2001 in analogous sequence. In the course of the experiment, the plots were left to their own resources. We recorded the survival of plants, increase in shoot length, number of leaves, number of branches, length and shape of leaves for those individuals that survived.

In accordance with McGraw \& Antonovics (1983), we calculated a 'selection coefficient' derived from the survivorship data as

$$
\text { Selection coefficient }=\left[1-\left(\frac{\text { Survival rate }}{\text { Highest survival rate at the respective site }}\right)\right]
$$

in order to assess the relative survivorship. A coefficient of zero indicates that an origin is the most successful at a particular target site with a selection advantage over the other origins, whereas a coefficient of one indicates a selection against the origin. 


\section{Statistical analyses}

\section{Habitat characteristics}

Since the majority of the data of habitat characteristics were not normally distributed, we transformed the data into ranks and used non-parametric statistics (proc rank, SAS Institute 2000; for appropriateness of rank transformation see Brunner \& Puri 2001). The data were, subsequently, subjected to a one-factorial ANOVA. We tested for significant country effects (proc glm; SAS Institute 2000) and performed Ryan-Einot-Gabriel-Welsch (REGWQ) multiple range tests for posthoc analyses.

\section{Field correlations}

Due to the fact that the majority of the predictor and response variables did not have a normal distribution we calculated Spearman's rank correlation coefficients for all combinations of 25 habitat characteristics (see Table 2) and 10 response parameters (see Table 3) derived from measurements on existing plants in the field (see Erfmeier \& Bruelheide 2004a). In doing so, the temperature data of specific periods were not correlated with the biometric data of previous periods; a total of 213 possible combinations resulted. We subsequently concentrated on the best relationships between the variables. We applied the Bonferroni adjustment for controlling the experiment-wise error rate.

Due to existing differences in habitat characteristics between the countries, we performed a supplementary one-factorial ANOVA (proc glm; SAS Institute 2000) to separate relationships between predictors and responses from a potential country effect. For each response parameter, we tested for country effects, including the best correlating variable that had passed the Bonferroni adjustment as covariate into the model to estimate a putative overlay of the effects. The covariate was only kept in the model if there was no country-covariate interaction.

\section{Reciprocal transplant experiment}

Henceforth, we regard 'origin' as the term describing the plants' provenance and 'target site' as the treatment factor site, to which the plants were crosswise (re-) transplanted.

All calculated parameters were tested for normal distribution (proc univariate, Shapiro-Wilkstatistics, SAS Institute 2000). Since the majority of the parameters examined were not normally distributed, the data were transformed into ranks before analyses of variance were performed.

For survivorship data, both factors were seen as fixed factors, with 'target site' reflecting environmental effects, and 'origin' indicating genetic effects. Significant target site-origin interactions reveal whether different origins react differently to the different sites. We applied a 
two-factorial ANOVA model on the population level using averages of the $n=3$ individuals per population (proc glm; SAS Institute 2000). For post-hoc tests we performed Ryan-Einot-GabrielWelsch (REGWQ) multiple range tests.

Due to the high loss rates during the survivorship experiment, the remaining data set lacked sufficient replicates to allow analysis of further effects of the target site on growth-dependent parameters. Therefore, subsequent analyses for the detection of origin-dependent responses could only be applied to the invaded environment in Ireland. The pre-transplantation rooting success was included as a covariate in the statistical models. We performed an iterative procedure to select the appropriate model: provided that there were no interactions between the treatment effect and the putative covariate, we tested for significant covariate effects. If the latter were detected the covariate was included in the model; otherwise, the model was implemented without considering the covariate. We applied a nested ANOVA model for morphological and growth traits at the level of the individual with factor 'population' (random) nested within 'country’ (proc glm; SAS Institute 2000). Post-hoc tests were realized with Ryan-Einot-Gabriel-Welsch (REGWQ) multiple range tests.

\section{Results}

\section{Habitat description}

Analysis of habitat characteristics showed clear differences between native and invaded sites (Table 2): Irish sites most often differed significantly from both the native Georgian and Spanish sites in edaphic parameters, in parameters of community properties and of microclimate. The base supply in the topsoil was highest at Irish sites with three to four times higher contents of exchangeable magnesium and potassium. With a median $\mathrm{pH}$ of 3.8, the Irish sites had the most acidic soil conditions. Correspondingly, the quantities of acidic cations, in particular those of aluminium and iron, were also high at the Irish sites, but showed no significant difference to the sites of the native Georgian populations. The cation exchange capacity (CEC) was highest at the Irish sites, with $324 \mu \mathrm{mol}_{\mathrm{c}} \mathrm{g}^{-1}$. In contrast, the highest proportion of basic cations in the total cation content was found at the Spanish sites, with a median value of about 97\%; whereas in Georgia and Ireland the base saturation was approximately $69 \%$ and $72 \%$, respectively. The invaded Irish sites differed significantly from all other sites in terms of organic material. Both the values of total organic $\mathrm{C}$ and organic $\mathrm{N}$ were significantly higher in Ireland and additionally the $\mathrm{C} / \mathrm{N}$ ratio of 27.17 was significantly higher at the Irish sites than at the native Georgian and Spanish ones. 
Table 2: Analysis of variance for habitat characteristics of Rhododendron ponticum sites. Edaphic parameters refer to exchangeable cations of the uppermost soil layer (CEC = cation exchange capacity; BS = base saturation). Microclimate parameters refer to the survey period from April 2000 to March 2001 for annual data and from October 2000 to March 2001 for winter data. Values are medians with $\mathrm{n}=6$ for each provenance, $\mathrm{P}$ values refer to ANOVA, $* \alpha=0.05$, ** $\alpha=$ $0.01, * * * \alpha=0.001$, n.s. $=$ not significant. GEO = Georgia, ESP $=$ Spain, IRE = Ireland. Different letters indicate significant differences according to the REGWQ-test.

\begin{tabular}{|c|c|c|c|c|c|c|c|c|c|}
\hline & d.f. & $\begin{array}{l}\text { Sum of } \\
\text { squares }\end{array}$ & $\begin{array}{l}\text { Mean } \\
\text { Square }\end{array}$ & F Value & $\mathbf{P}$ & & GEO & ESP & IRE \\
\hline \multicolumn{10}{|l|}{ Edaphic parameters } \\
\hline $\mathrm{Ca}\left[\mu \mathrm{mol}_{\mathrm{c}} \mathrm{g}^{-1}\right]$ & 2 & 109.0 & 54.5 & 2.18 & 0.1479 & n.s. & 64.20 & 179.42 & 105.70 \\
\hline $\mathrm{Mg}\left[\mu \mathrm{mol}_{\mathrm{c}} \mathrm{g}^{-1}\right]$ & 2 & 340.3 & 170.2 & 17.71 & 0.0001 & $\star *$ & $20.88^{\mathrm{b}}$ & $36.47^{\mathrm{b}}$ & $92.66^{a}$ \\
\hline $\mathrm{K}\left[\mu \mathrm{mol}_{\mathrm{c}} \mathrm{g}^{-1}\right]$ & 2 & 195.1 & 97.6 & 4.76 & 0.0251 & * & $6.95^{b}$ & $6.69^{b}$ & $21.02^{\mathrm{a}}$ \\
\hline Al $\left[\mu \mathrm{mol}_{\mathrm{c}} \mathrm{g}^{-1}\right]$ & 2 & 253.4 & 126.7 & 6.03 & 0.0119 & * & $29.89^{a}$ & $0.46^{b}$ & $3.40^{\mathrm{ab}}$ \\
\hline $\mathrm{Mn}\left[\mu \mathrm{mol}_{\mathrm{c}} \mathrm{g}^{-1}\right]$ & 2 & 57.0 & 28.5 & 0.83 & 0.4538 & n.s. & 5.52 & 6.16 & 3.20 \\
\hline $\mathrm{Fe}\left[\mu \mathrm{mol}_{\mathrm{c}} \mathrm{g}^{-1}\right]$ & 2 & 313.5 & 156.8 & 12.56 & 0.0006 & $\star \star$ & $0.17^{\mathrm{a}}$ & $0.00^{\mathrm{b}}$ & $0.66^{\mathrm{a}}$ \\
\hline $\mathrm{CEC}\left[\mu \mathrm{mol}_{\mathrm{c}} \mathrm{g}^{-1}\right]$ & 2 & 226.3 & 113.2 & 6.58 & 0.0089 & ** & $139.56^{b}$ & $231.21^{\mathrm{ab}}$ & $324.39^{\mathrm{a}}$ \\
\hline BS [\%] & 2 & 256.0 & 128.0 & 8.40 & 0.0036 & ** & $69.29^{\mathrm{b}}$ & $96.97^{\mathrm{a}}$ & $71.89^{\mathrm{b}}$ \\
\hline $\mathrm{Al} / \mathrm{Ca}$ & 2 & 213.8 & 106.9 & 5.56 & 0.0156 & * & $0.54^{\mathrm{a}}$ & $0.01^{\mathrm{b}}$ & $0.03^{\mathrm{ab}}$ \\
\hline $\mathrm{N}[\%]$ & 2 & 241.3 & 120.7 & 7.44 & 0.0057 & ** & $0.55^{\mathrm{b}}$ & $0.82^{b}$ & $1.73^{\mathrm{a}}$ \\
\hline $\mathrm{C}[\%]$ & 2 & 378.8 & 189.4 & 16.30 & 0.0002 & ** & $9.59^{b}$ & $14.44^{b}$ & $47.18^{a}$ \\
\hline $\mathrm{C} / \mathrm{N}$ & 2 & 272.3 & 136.2 & 9.63 & 0.0020 & $\star *$ & $16.75^{\mathrm{b}}$ & $17.96^{\mathrm{b}}$ & $27.17^{\mathrm{a}}$ \\
\hline $\mathrm{pH}$ & 2 & 364.0 & 182.0 & 22.66 & $<0.0001$ & $\star * \star *$ & $4.4^{\mathrm{b}}$ & $6.0^{\mathrm{a}}$ & $3.8^{\mathrm{c}}$ \\
\hline \multicolumn{10}{|l|}{ Community properties } \\
\hline Elevation [m a.s.I.] & 2 & 240.3 & 120.2 & 7.40 & 0.0058 & $\star *$ & $705^{a}$ & $700^{a}$ & $90^{\mathrm{b}}$ \\
\hline No. of species & 2 & 115.6 & 57.8 & 2.36 & 0.1289 & n.s. & 13.5 & 26.5 & 17.0 \\
\hline Canopy cover [\%] & 2 & 179.1 & 89.5 & 4.54 & 0.0287 & * & $74.5^{\mathrm{a}}$ & $75.0^{\mathrm{a}}$ & $62.5^{\mathrm{b}}$ \\
\hline \multicolumn{10}{|l|}{ Microclimate } \\
\hline Relative light intensity [\%] & 2 & 2.4 & 1.2 & 0.04 & 0.9601 & n.s. & 0.111 & 0.108 & 0.094 \\
\hline No. of frost days $\left[\mathrm{yr}^{-1}\right]$ & 2 & 212.1 & 106.1 & 19.48 & 0.0002 & $\star \star$ & $37.0^{\mathrm{a}}$ & $0.0^{\mathrm{b}}$ & $27.5^{\mathrm{a}}$ \\
\hline Winter heat sum $\left[{ }^{\circ} \mathrm{C}\right]$ & 2 & 155.4 & 77.7 & 6.69 & 0.0112 & * & $480.8^{\mathrm{ab}}$ & $1031.5^{\mathrm{a}}$ & $306.4^{\mathrm{b}}$ \\
\hline Annual heat sum $\left[{ }^{\circ} \mathrm{C}\right]$ & 2 & 183.0 & 91.5 & 11.32 & 0.0017 & ** & $2449.0^{\mathrm{a}}$ & $3224.2^{\mathrm{a}}$ & $1585.4^{\mathrm{b}}$ \\
\hline Annual coldness sum $\left[{ }^{\circ} \mathrm{C}\right]$ & 2 & 207.0 & 103.5 & 22.38 & $<0.0001$ & $\star * \star *$ & $-32.6^{\mathrm{b}}$ & $0.0^{\mathrm{a}}$ & $-8.0^{\mathrm{b}}$ \\
\hline Seasonal temperature amplitude $\left[{ }^{\circ} \mathrm{C} \mathrm{yr}^{-1}\right]$ & 2 & 234.5 & 117.3 & 30.92 & $<0.0001$ & 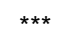 & $17.4^{\mathrm{a}}$ & $12.5^{\mathrm{b}}$ & $10.6^{\mathrm{c}}$ \\
\hline Mean of warmest month $2000\left[{ }^{\circ} \mathrm{C}\right]$ & 2 & 204.5 & 102.3 & 16.25 & 0.0004 & $\star *$ & $20.5^{a}$ & $21.0^{\mathrm{a}}$ & $14.4^{\mathrm{b}}$ \\
\hline Mean of warmest month $2001\left[{ }^{\circ} \mathrm{C}\right]$ & 2 & 207.0 & 103.5 & 17.01 & 0.0003 & ** & $19.9^{\mathrm{a}}$ & $21.5^{\mathrm{a}}$ & $14.4^{\mathrm{b}}$ \\
\hline Mean of coldest month $\left[{ }^{\circ} \mathrm{C}\right]$ & 2 & 160.5 & 80.3 & 8.06 & 0.0060 & ** & $3.1^{\mathrm{b}}$ & $8.5^{\mathrm{a}}$ & $4.0^{\mathrm{b}}$ \\
\hline
\end{tabular}

Although we found a lower median absolute number of 17.0 and 13.5 species at the Irish and Georgian sites, respectively, than at the Spanish ones (26.5 species), this difference was not significant. Native and invaded sites differed in patterns of community physiognomy: with a median of $62.5 \%$ the canopy cover was significantly lower at the Irish sites than at the Georgian and Spanish ones. In any case, with approximately $10 \%$ of incident light, the relative light intensity reaching the rhododendron shrub layer was similar in all countries.

The temperature course during the observation period showed a very distinct pattern differing between the three countries (Fig. 1). In general, the temperatures were highest in Spanish populations. Both the annual and the winter heat sum of Spanish sites did not differ significantly from Georgian sites, but we recorded a higher number of day degrees in the annual heat sum in the two countries with native populations than in Ireland (Table 2). Similarly, the mean temperatures of 


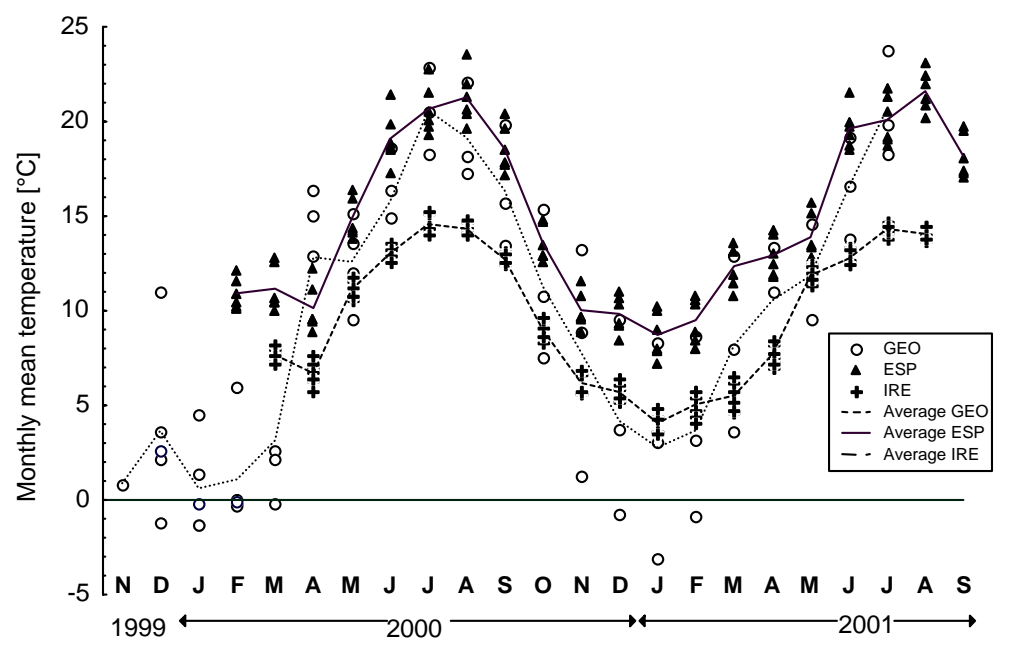

Fig. 1: Monthly mean temperature recorded at height of rhododendron shrub layer at all study sites during the observation period (11/1999 to 09/2001). Means are given for each population; the lines represent the country's averages ( $n=6$ for ESP and IRE; $\mathrm{n}=4$ for GEO)

the respective warmest months in Georgia (July) and in Spain (August) were higher than in Ireland (July). The coldest sites were encountered in Georgia, even though the calculated annual coldness sum [i.e. the number of frost days and the mean temperatures of the coldest month (January for all countries)] detected no significant difference between the Georgian and the Irish sites (Fig. 1, Table 2). This circumstance is mainly due to the wide altitudinal range of Georgian rhododendron populations, which includes single sites that clearly exhibited colder conditions than in Irish populations; whilst others were absolutely comparable to those in the invaded area. Apart from this large within-country variation, Georgian sites also showed the highest seasonal temperature amplitude. With a mean temperature amplitude of $17.4^{\circ} \mathrm{C}$ per annum in Georgia, the temperature alternation was significantly more extreme than in Spain and Ireland. Moreover, seasonal variability in Ireland was also significantly lower than at the Spanish sites; thus, offering the most constant temperature conditions in the course of the year. Additional registration of soil moisture during the vegetation period of 2000 (01-02-2000 to 30-11-2000) displayed a mean relative soil humidity of $13.7 \%$ in the Spanish population (L); whereas the Irish reference population (O) showed a higher mean relative humidity with $47.8 \%$.

\section{Field correlates}

For all groups of predictor variables, we found significant Spearman rank correlations with the assigned response variables (Table 3). In particular, there was a strong relationship between edaphic parameters and the response parameters of increase. We found magnesium and potassium to be highly positively correlated with the increase in shoot length, regardless of the year of observation (Table 3). Similarly, we found a significant relationship between the quantity of organic carbon in the soil and nearly all response variables. Among the structural parameters, it was primarily 
Table 3: Significant Spearman rank correlation coefficients of habitat characteristics (predictor variables) with parameters of growth and seedling recruitment of existing Rhododendron ponticum plants in the field (response variables). Levels of significance are given in italics. Best positive and negative correlation coefficients are indicated in bold. Framed values highlight those correlations that passed Bonferroni correction. The predictor parameters Ca, Al, Mn, BS, Al/Ca, Number of species, Relative light intensity and Mean of coldest month were omitted due to a lack of any significant relationships. X = Correlations not tested.

\begin{tabular}{|c|c|c|c|c|c|c|c|c|c|c|c|c|c|c|c|c|c|}
\hline & Mg & $\mathbf{K}$ & $\mathrm{Fe}$ & CEC & $\mathbf{N}$ & C & $\mathrm{C} / \mathrm{N}$ & $\mathrm{pH}$ & $\begin{array}{c}\text { Canopy } \\
\text { cover }\end{array}$ & Elevation & $\begin{array}{c}\text { Annual } \\
\text { heat sum }\end{array}$ & $\begin{array}{c}\text { Winter } \\
\text { heat sum }\end{array}$ & $\begin{array}{c}\text { No. of } \\
\text { frost days }\end{array}$ & $\begin{array}{c}\text { Annual } \\
\text { coldness } \\
\text { sum }\end{array}$ & $\begin{array}{c}\text { Seasonal } \\
\text { temperature } \\
\text { amplitude }\end{array}$ & $\begin{array}{c}\text { Mean of } \\
\text { e warmest } \\
\text { month } \\
2000\end{array}$ & $\begin{array}{c}\text { Mean of } \\
\text { warmest } \\
\text { month } \\
2001\end{array}$ \\
\hline $\mathrm{N}$ & 18 & 18 & 18 & 18 & 18 & 18 & 18 & 18 & 18 & 18 & 15 & 15 & 15 & 15 & 15 & 15 & 15 \\
\hline $\begin{array}{l}\text { Increase in } \\
\text { shoot length }\end{array}$ & $\begin{array}{c}\mathbf{0 . 7 6 9} \\
0.0002\end{array}$ & \begin{tabular}{|c|}
0.494 \\
0.0370
\end{tabular} & & $\begin{array}{c}0.668 \\
0.0025\end{array}$ & & $\begin{array}{c}0.565 \\
0.0147\end{array}$ & $\begin{array}{c}0.494 \\
0.0370\end{array}$ & & & $\begin{array}{l}-0.736 \\
0.0005\end{array}$ & $x$ & $x$ & $x$ & $x$ & $x$ & $x$ & $x$ \\
\hline $\begin{array}{l}\text { Increase in } \\
\text { shoot length }\end{array}$ & $\begin{array}{c}\mathbf{0 . 8 7 2} \\
<0.0001 \\
\end{array}$ & \begin{tabular}{|c|}
0.717 \\
0.0008
\end{tabular} & & $\begin{array}{c}0.678 \\
0.0020\end{array}$ & $\begin{array}{c}0.482 \\
0.0428\end{array}$ & $\begin{array}{c}0.631 \\
0.0050\end{array}$ & $\begin{array}{c}0.532 \\
0.0232\end{array}$ & $\begin{array}{l}-0.484 \\
0.0418\end{array}$ & & $\begin{array}{l}-0.773 \\
0.0002 \\
\end{array}$ & & $x$ & $x$ & $x$ & $\begin{array}{l}-0.764 \\
0.0009\end{array}$ & $\begin{array}{l}-0.643 \\
0.0097\end{array}$ & $x$ \\
\hline $\begin{array}{l}\text { Increase in } \\
\text { shoot length }\end{array}$ & $\begin{array}{c}0.668 \\
0.0025\end{array}$ & $\begin{array}{c}0.546 \\
0.0191\end{array}$ & $\begin{array}{c}0.607 \\
0.0076\end{array}$ & & & $\begin{array}{c}0.540 \\
0.0208\end{array}$ & $\begin{array}{c}0.569 \\
0.0138\end{array}$ & $\begin{array}{l}-0.715 \\
0.0008\end{array}$ & & $\begin{array}{l}-0.766 \\
0.0002 \\
\end{array}$ & $\begin{array}{l}-0.632 \\
0.0115\end{array}$ & $\begin{array}{l}-0.529 \\
0.0428\end{array}$ & $\begin{array}{c}0.677 \\
0.0056\end{array}$ & $\begin{array}{l}-0.614 \\
0.0149\end{array}$ & $\begin{array}{l}-0.707 \\
0.0032\end{array}$ & $\begin{array}{l}-0.725 \\
0.0022\end{array}$ & $\begin{array}{l}-0.696 \\
0.0039\end{array}$ \\
\hline $\begin{array}{l}\text { Number of } \\
\text { Internodes }\end{array}$ & $\begin{array}{c}0.522 \\
0.0261\end{array}$ & & & & & $\begin{array}{c}0.472 \\
0.0480\end{array}$ & $\begin{array}{c}0.543 \\
0.0198\end{array}$ & & & & & & & & $\begin{array}{l}-0.559 \\
0.0302\end{array}$ & & \\
\hline $\begin{array}{l}\text { Leaf number } \\
1999\end{array}$ & \begin{tabular}{|c|}
0.806 \\
$<0.0001$ \\
\end{tabular} & $\begin{array}{c}0.534 \\
0.0226\end{array}$ & & $\begin{array}{c}0.612 \\
0.0070\end{array}$ & $\begin{array}{c}0.647 \\
0.0037\end{array}$ & $\begin{array}{c}0.728 \\
0.0006 \\
\end{array}$ & $\begin{array}{c}0.501 \\
0.0344\end{array}$ & & & $\begin{array}{l}-0.684 \\
0.0018\end{array}$ & $x$ & $x$ & $x$ & $x$ & $x$ & $x$ & $x$ \\
\hline $\begin{array}{l}\text { Leaf number } \\
2000\end{array}$ & \begin{tabular}{|c|}
$\mathbf{0 . 8 2 0}$ \\
$<0.0001$ \\
\end{tabular} & $\begin{array}{c}0.569 \\
0.0138\end{array}$ & & $\begin{array}{c}0.616 \\
0.0065\end{array}$ & $\begin{array}{c}0.705 \\
0.0011\end{array}$ & \begin{tabular}{|c|}
0.759 \\
0.0003 \\
\end{tabular} & $\begin{array}{c}0.482 \\
0.0428\end{array}$ & & & $\begin{array}{l}-0.720 \\
0.0008\end{array}$ & $\begin{array}{l}-0.539 \\
0.0380\end{array}$ & $\mathrm{x}$ & $x$ & $\mathrm{x}$ & $\begin{array}{c}-0.914 \\
<0.0001\end{array}$ & $\begin{array}{l}-0.689 \\
0.0045\end{array}$ & $x$ \\
\hline $\begin{array}{l}\text { Leaf number } \\
2001\end{array}$ & $\begin{array}{c}0.703 \\
0.0011\end{array}$ & $\begin{array}{c}0.647 \\
0.0037\end{array}$ & $\begin{array}{c}0.633 \\
0.0048\end{array}$ & & $\begin{array}{c}0.556 \\
0.0165\end{array}$ & $\begin{array}{c}0.655 \\
0.0032\end{array}$ & $\begin{array}{c}0.548 \\
0.0186\end{array}$ & $\begin{array}{l}-0.721 \\
0.0007\end{array}$ & & $\begin{array}{l}-0.770 \\
0.0002 \\
\end{array}$ & $\begin{array}{l}-0.521 \\
0.0462\end{array}$ & & & & $\begin{array}{l}-0.825 \\
0.0002 \\
\end{array}$ & $\begin{array}{l}-0.643 \\
0.0097\end{array}$ & $\begin{array}{l}-0.596 \\
0.0189\end{array}$ \\
\hline $\begin{array}{r}\text { Sum of leaf } \\
1999-2001\end{array}$ & \begin{tabular}{|c|}
$\mathbf{0 . 8 3 3}$ \\
$<0.0001$ \\
\end{tabular} & \begin{tabular}{|c|}
0.605 \\
0.0078
\end{tabular} & & $\begin{array}{c}0.646 \\
0.0038\end{array}$ & $\begin{array}{c}0.531 \\
0.0235\end{array}$ & $\begin{array}{c}0.660 \\
0.0029\end{array}$ & $\begin{array}{c}0.549 \\
0.0182\end{array}$ & $\begin{array}{l}-0.469 \\
0.0497\end{array}$ & & $\begin{array}{c}-0.832 \\
<0.0001\end{array}$ & $x$ & $x$ & $\mathrm{x}$ & $x$ & $x$ & $x$ & $x$ \\
\hline Seedlings 2000 & $\begin{array}{c}0.691 \\
0.0015\end{array}$ & $\begin{array}{c}0.491 \\
0.0385\end{array}$ & & $\begin{array}{c}0.682 \\
0.0018\end{array}$ & $\begin{array}{c}0.560 \\
0.0156\end{array}$ & $\begin{array}{c}0.637 \\
0.0045\end{array}$ & $\begin{array}{c}0.551 \\
0.0178\end{array}$ & & & $\begin{array}{l}-0.537 \\
0.0215\end{array}$ & & $x$ & $x$ & & & & $x$ \\
\hline Seedlings 2001 & $\begin{array}{c}0.679 \\
0.0020\end{array}$ & & & $\begin{array}{c}0.564 \\
0.0147\end{array}$ & $\begin{array}{c}0.688 \\
0.0016\end{array}$ & \begin{tabular}{|c|}
$\mathbf{0 . 8 0 1}$ \\
$<0.0001$
\end{tabular} & $\begin{array}{c}0.676 \\
0.0021\end{array}$ & & $\begin{array}{l}-0.575 \\
0.0126\end{array}$ & $\begin{array}{l}-0.599 \\
0.0087\end{array}$ & $\begin{array}{l}-0.546 \\
0.0353\end{array}$ & & & & $\begin{array}{l}-0.606 \\
0.0166\end{array}$ & $\begin{array}{l}-0.572 \\
0.0258\end{array}$ & $\begin{array}{l}-0.625 \\
0.0127\end{array}$ \\
\hline
\end{tabular}



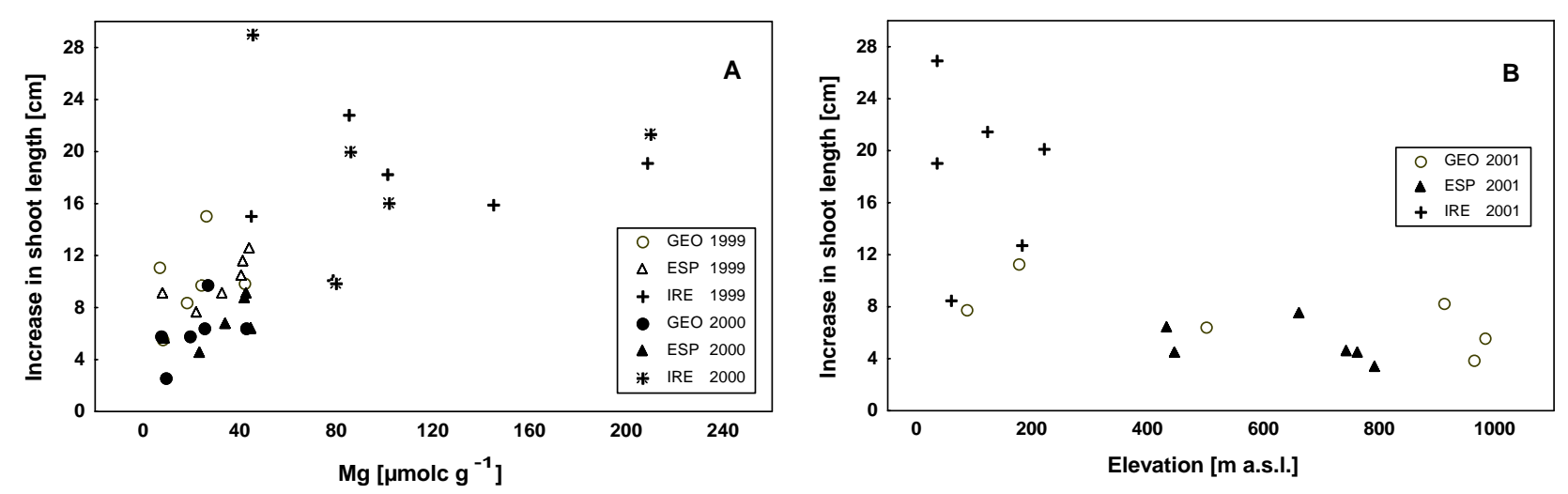

Fig. 2: A) Relationship between increase of Rhododendron ponticum shoots in 1999, 2000 and Mg content in soil. B) Relationship between increase of Rhododendron ponticum shoots in 2001 and elevation of the sites. For statistical details referring to rank transformed data see Table 3 and Table 4.

elevation that showed significant negative correlations with the plants' increases-both with increases in shoot length and in the number of leaves. With the exception of the 'number of frost days', we found a negative relationship with the response variables for all other significant temperature-related parameters. Taking the Bonferroni correction into consideration (Table 3), it was mainly the predictors Mg, C, ‘elevation’ and ‘seasonal temperature amplitude’ that suggest a probable relationship to the investigated response parameters. In general, shoot length parameters were most often positively correlated with high Mg contents and decreased with increasing elevation; whereas leaf production parameters were particularly associated with the seasonal temperature amplitude. The results of the analysis of variance to test for country and covariate

Table 4: Analysis of variance for response variables of Rhododendron ponticum. The terms reflect effects of the country and the appropriate best correlating predictor variable included as covariate in the model for relationships that passed the Bonferroni test (see Table 3). Response variables that are not listed here did not meet the criteria. $\mathrm{N}=18, \mathrm{P}$ values refer to ANOVA, $* \alpha=0.05, * * \alpha=0.01$, n.s. $=$ not significant. Effects of the covariate are given in italics.

\begin{tabular}{|c|c|c|c|c|c|c|c|}
\hline Response variable & & d.f. & $\begin{array}{l}\text { Sum of } \\
\text { squares }\end{array}$ & $\begin{array}{c}\text { Mean } \\
\text { Square }\end{array}$ & F Value & $\mathbf{P}$ & \\
\hline \multirow[t]{2}{*}{ Increase in shoot length 1999} & country & 2 & 8.5 & 4.3 & 0.32 & 0.7346 & n.s. \\
\hline & $M g$ & 1 & 69.6 & 69.6 & 5.14 & 0.0398 & * \\
\hline \multirow[t]{2}{*}{ Increase in shoot length 2000} & country & 2 & 18.0 & 9.0 & 1.28 & 0.3080 & n.s. \\
\hline & $M g$ & 1 & 61.1 & 61.1 & 8.72 & 0.0105 & * \\
\hline \multirow[t]{2}{*}{ Increase in shoot length 2001} & country & 2 & 98.0 & 49.0 & 6.72 & 0.0090 & ** \\
\hline & Elevation & 1 & 39.4 & 39.4 & 5.41 & 0.0356 & * \\
\hline \multirow[t]{2}{*}{ Leaf number 1999} & country & 2 & 74.7 & 37.3 & 5.50 & 0.0173 & * \\
\hline & $M g$ & 1 & 9.1 & 9.1 & 1.34 & 0.2671 & n.s. \\
\hline \multirow[t]{2}{*}{ Leaf number 2000} & country & 2 & 12.6 & 6.3 & 1.35 & 0.2988 & n.s. \\
\hline & Seasonal fluctuation in temperature & 1 & 22.3 & 22.3 & 4.77 & 0.0516 & n.s. \\
\hline \multirow[t]{2}{*}{ Leaf number 2001} & country & 2 & 42.3 & 21.1 & 2.57 & 0.1217 & n.s. \\
\hline & Seasonal fluctuation in temperature & 1 & 23.7 & 23.7 & 2.88 & 0.1180 & n.s. \\
\hline \multirow[t]{2}{*}{ Sum of leaf number $1999-2000$} & country & 2 & 30.6 & 15.3 & 2.08 & 0.1712 & n.s. \\
\hline & Seasonal fluctuation in temperature & 1 & 3.5 & 3.5 & 0.48 & 0.5029 & n.s. \\
\hline \multirow[t]{2}{*}{ Seedlings 2001} & country & 2 & 43.6 & 21.8 & 3.04 & 0.0801 & n.s. \\
\hline & C & 1 & 10.6 & 10.6 & 1.47 & 0.2453 & n.s. \\
\hline
\end{tabular}


effects are listed in Table 4. The inclusion of the respective best correlating variable leads to only a few numbers of significant effects for both country and covariate. Nevertheless, the analysis of variance revealed a significant importance of the $\mathrm{Mg}$ covariate for the increase of rhododendron shoots in 1999 and 2000; whilst there was no country effect (Table 4, Fig. 2 A). As for the increase in shoot length in 2001 (Fig. 2 B), we found significant effects for both factors: a highly significant one for the class variable country and a significant effect for the covariate 'elevation' on the investigated response parameter. Summarizing, we found that the edaphic factor Mg had the closest relationship with the growth of rhododendron.

\section{Reciprocal transplant experiment}

Survivorship of rhododendron individuals was strongly affected by both environmental (target site) and genetic (origin) effects, as well as by target site-origin interactions (Table 5). This means that the invasive and native origins responded differently to different environments. The Georgian genotype was the most successful one, i.e. it consistently exhibited comparatively high survival rates at all treatment sites (Fig. 3). The Spanish genotype was ranked at an intermediate position; whereas the invasive Irish genotype showed the significantly lowest values. In general, survivorship was favoured in ascending order from the Spanish over the Georgian towards the Irish target site (Table 5, Fig. 3). Strong interactions between the two main factors are mainly due to the steep increase in the reaction norm of survivorship data of the Spanish origin towards the Irish target site, moving from a median survival rate of zero to one of hundred.

We found no genotype that survived best at all three sites, although the Georgian genotype reached lowest mean selection coefficients indicating a selection advantage over the other origins (Table 6). In contrast, survivorship data of the invasive Irish genotype points at selection against this origin. A particularly high affinity to the respective home site, indicating specific adaptation to the area of provenance could only be detected for the Georgian origin.

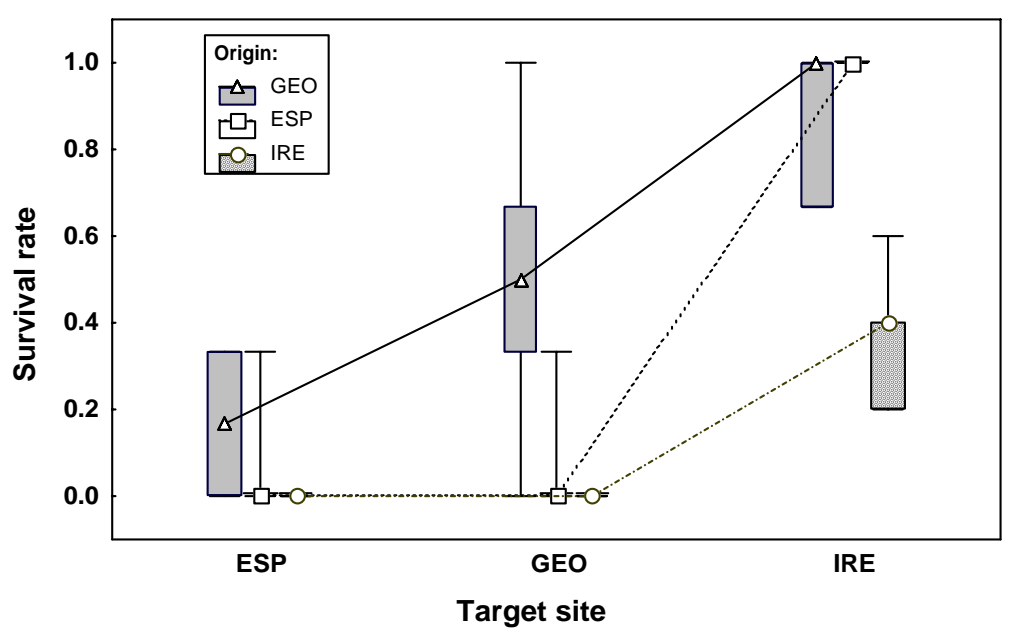

Fig. 3: Survivorship of transplanted Rhododendron ponticum individuals at different target sites. Medians, quartiles, minimum and maximum refer to survivorship per population $(n=6)$. Target sites are ordered according to increasing values. 
Table 5: Analysis of variance for survivorship of transplanted/replanted Rhododendron ponticum individuals. The terms reflect effects of genotype (origin), environment (target site) and their interaction on the survival rates of transplanted individuals. ANOVA was performed on population level with survivorship means for each population. GEO = Georgia, ESP = Spain, IRE = Ireland. Different letters indicate significant differences according to the REGWQ-test.

\begin{tabular}{llccccccccccc}
\hline Parameter & & d.f. & $\begin{array}{c}\text { Sum of } \\
\text { squares }\end{array}$ & $\begin{array}{c}\text { Mean } \\
\text { squares }\end{array}$ & F & P & GEO & ESP & IRE \\
\hline Survivorship & origin & 2 & 1849.3 & 924.7 & 20.24 & $<0.0001^{* * *}$ & a & b & c \\
& target site & 2 & 6822.1 & 3411.1 & 74.66 & $<0.0001^{* *}$ & b & b & a \\
& target site*origin & 4 & 782.2 & 195.6 & 4.28 & $0.0051^{* *}$ & & & \\
\hline
\end{tabular}

Table 6: 'Selection coefficient', derived from survival rates for Rhododendron ponticum genotypes (origins), transplanted/replanted into target sites. GEO = Georgia, ESP = Spain, IRE = Ireland. Data are averages of six populations per combination of origin and target site.

\begin{tabular}{|c|c|c|c|c|c|}
\hline & \multicolumn{5}{|c|}{ Origin } \\
\hline & & GEO & ESP & IRE & Means \pm SD \\
\hline \multirow{4}{*}{ 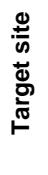 } & GEO & 0 & 0.89 & 1 & $0.63 \pm 0.55$ \\
\hline & ESP & 0 & 0.67 & 1 & $0.56 \pm 0.51$ \\
\hline & IRE & 0.11 & 0 & 0.63 & $0.25 \pm 0.34$ \\
\hline & Means \pm SD & $0.37 \pm 0.41$ & $0.59 \pm 0.49$ & $0.88 \pm 0.20$ & \\
\hline
\end{tabular}
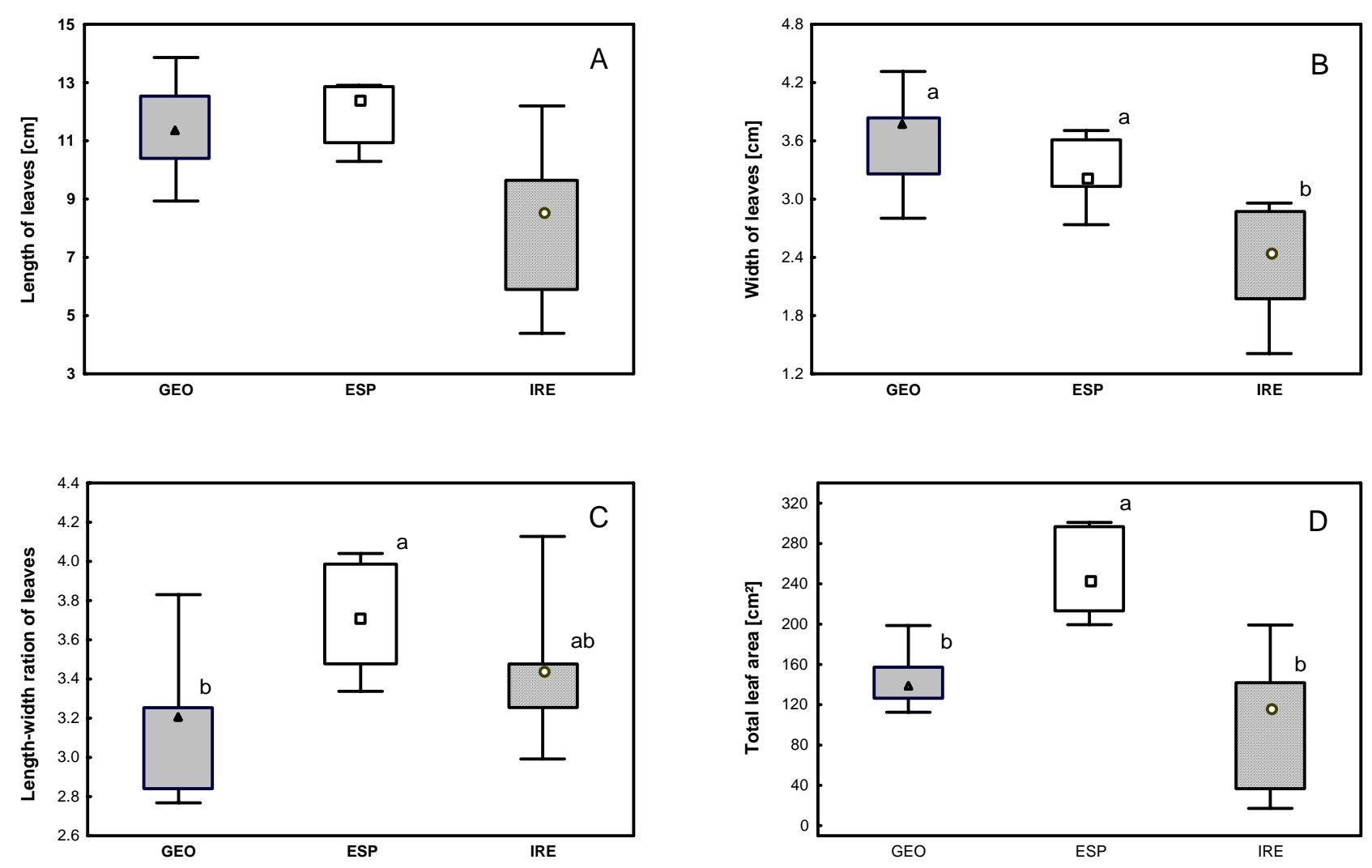

Fig. 4: Leaf characteristics of Georgian, Spanish and Irish Rhododendron ponticum origins re-/transplanted to the Irish site. A) Absolute length of leaves, B) Absolute width of leaves, C) Length-width ratio of leaves, D) Total leaf area. Different letters indicate significant differences according to the REGWQ-test. For P values see Table 7. 
Table 7: Analysis of variance for morphological and growth traits of Rhododendron ponticum individuals re/transplanted to the Irish site. ANOVA was performed on individual's level. The terms reflect effects of genotype (origin) and of rooting success (covar) on transplanted individuals. The covariate was only considered in the model in cases of significance and is, then, given in italics. GEO = Georgia, ESP = Spain, IRE = Ireland. Different letters indicate significant differences according to the REGWQ-test.

\begin{tabular}{|c|c|c|c|c|c|c|c|c|c|c|}
\hline Parameter & & d.f. & $\begin{array}{l}\text { Sum of } \\
\text { squares }\end{array}$ & $\begin{array}{c}\text { Mean } \\
\text { squares }\end{array}$ & $\mathbf{F}$ & $\mathbf{P}$ & & GEO & ESP & IRE \\
\hline \multicolumn{11}{|l|}{ Morphological traits } \\
\hline \multirow[t]{2}{*}{ Length of leaf } & origin & 2 & 353.0 & 176.5 & 1.71 & 0.2062 & n.s. & & & \\
\hline & covar & 1 & 241.6 & 241.6 & 4.39 & 0.0490 & * & & & \\
\hline \multirow[t]{2}{*}{ Shape of leaf } & origin & 2 & 202.3 & 101.2 & 0.85 & 0.4446 & n.s. & & & \\
\hline & covar & 1 & 230.6 & 230.6 & 4.43 & 0.0481 & * & & & \\
\hline Width of leaf & origin & 2 & 1657.2 & 828.6 & 8.29 & 0.0029 & $\star \star$ & $\mathrm{a}$ & $\mathrm{a}$ & $b$ \\
\hline \multirow[t]{2}{*}{ Leaf area } & origin & 2 & 139.9 & 70.0 & 0.78 & 0.4716 & n.s. & & & \\
\hline & covar & 1 & 504.7 & 504.7 & 8.13 & 0.0099 & $\star \star$ & & & \\
\hline Length-width ratio & origin & 2 & 951.8 & 475.9 & 3.95 & 0.0378 & * & $\mathrm{b}$ & $\mathrm{a}$ & ba \\
\hline Total leaf area & origin & 2 & 1483.7 & 741.8 & 11.42 & 0.0004 & $\star \star$ & $\mathrm{b}$ & $\mathrm{a}$ & $b$ \\
\hline \multirow[t]{2}{*}{ Maximum leaf area } & origin & 2 & 51.8 & 25.9 & 0.39 & 0.684 & n.s. & & & \\
\hline & covar & 1 & 804.3 & 804.3 & 10.24 & 0.0045 & ** & & & \\
\hline \multirow[t]{2}{*}{ Maximum length of leaf } & origin & 2 & 238.4 & 119.2 & 1.94 & 0.1637 & n.s. & & & \\
\hline & covar & 1 & 566.8 & 566.8 & 7.82 & 0.0111 & * & & & \\
\hline \multirow[t]{2}{*}{ Maximum width of leaf } & origin & 2 & 149.8 & 74.9 & 0.88 & 0.4273 & n.s. & & & \\
\hline & covar & 1 & 563.1 & 563.1 & 7.25 & 0.014 & * & & & \\
\hline \multicolumn{11}{|l|}{ Growth traits } \\
\hline \multirow[t]{2}{*}{ Increase in shoot length -AGR } & origin & 2 & 1530.4 & 765.2 & 4.61 & 0.0225 & * & $b$ & $\mathrm{a}$ & $b$ \\
\hline & covar & 1 & 593.9 & 593.9 & 5.94 & 0.0219 & * & & & \\
\hline Increase in shoot length - RGR & origin & 2 & 1599.2 & 799.6 & 3.67 & 0.0485 & * & $b$ & $\mathrm{a}$ & $\mathrm{a}$ \\
\hline Increase corrected by pre-transplant & origin & 2 & 1785.5 & 892.7 & 4.88 & 0.0215 & * & b & a & a \\
\hline Increase corrected by pre-transplant & origin & 2 & 1372.9 & 686.5 & 3.54 & 0.0527 & n.s. & & & \\
\hline \multirow[t]{2}{*}{ Leaf number } & origin & 2 & 1521.5 & 760.8 & 5.47 & 0.0107 & * & $\mathrm{a}$ & $\mathrm{a}$ & a \\
\hline & covar & 1 & 698.3 & 698.3 & 4.74 & 0.0388 & * & & & \\
\hline
\end{tabular}

Analysis of variance for traits of those individuals that had been propagated by cuttings and that subsequently had been re- and transplanted to the Irish site showed significant origin effects for both morphological and growth traits (Table 7). For those morphological traits with a significant effect of the pre-experimental rooting success (as covariate), no origin effect could be detected. The width of leaves of Spanish and Georgian origin was significantly wider than that of Irish plants (Fig. 4). The length of leaves showed no difference between the origins; whereas the total leaf area was highest for Spanish rhododendrons. The length-width ratio of leaves, which is seen as relatively stable morphological trait and presumed to be less affected by the environment, was highest in Spanish and lowest in Georgian individuals. The Irish leaves were ranked at an intermediate position (Fig. 4).

Traits of vegetative growth exhibit a distinction between Spanish and Irish rhododendron on the one hand, and Georgian plants, on the other hand (Table 7). Although the post-hoc test revealed no significant differences, the number of leaves was generally higher in Spanish and Irish plants. The total increase in shoot length at the Irish site was highest in Irish rhododendron. For both traits, the Irish origin had an extremely high variability within origin (Fig. 5). 

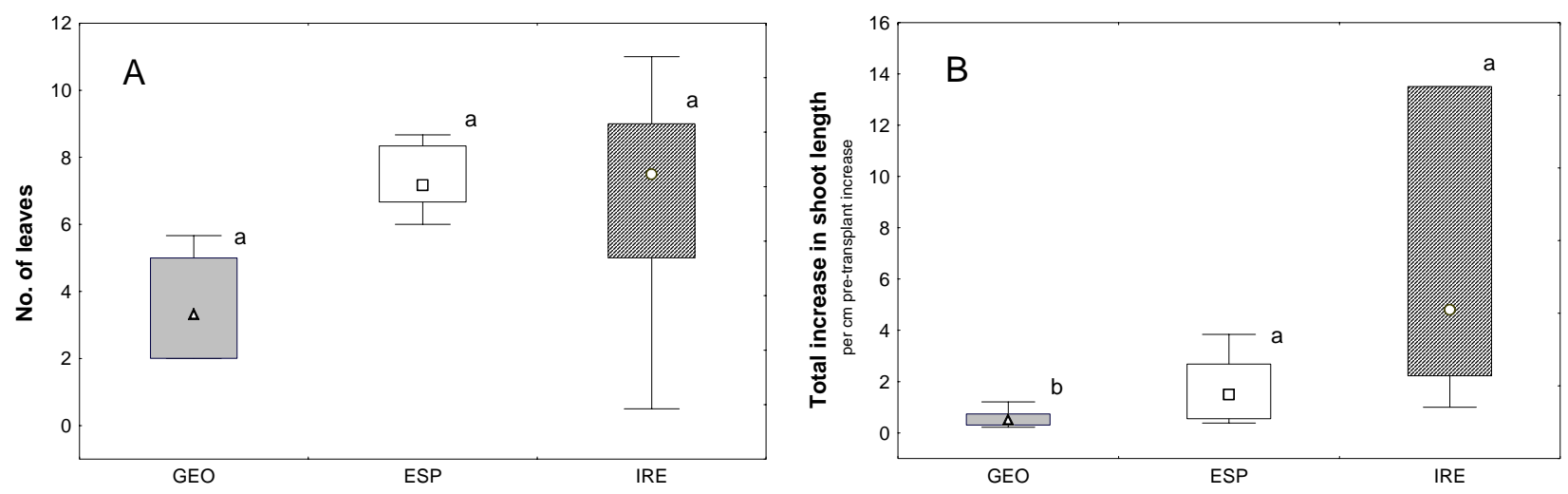

Fig. 5: Vegetative growth of Georgian, Spanish and Irish Rhododendron ponticum origins re-/transplanted to the Irish site. A) Absolute number of leaves, B) Total increase in shoot length. Different letters indicate significant differences according to the REGWQ-test. For P values see Table 7.

\section{Discussion}

\section{Habitat quality}

We found evidence for a high invasibility of habitats in the British Isles for Rhododendron ponticum. The new habitat clearly differed in both edaphic and climatic conditions from the homesite conditions of Rhododendron ponticum in that there was a more suitable environment at the Irish sites. As for rhododendron stands in the British Isles Cross (1975) characterized the soils as being low in cation exchange capacity and in potassium contents. The soil conditions in our current Irish data were similar; however, despite the low values, the cation supply in Irish soils was still higher than at native rhododendron sites in Georgia and at most of the investigated Spanish sites. Strong correlations between a thus more favourable nutrient supply and enhanced responses of growth parameters in Ireland seem to confirm the hypothesis of higher resource availability for rhododendron in the new territory. The crucial effect of soil fertility in the course of invasions has been repeatedly demonstrated (Hobbs \& Atkins 1988; Burke \& Grime 1996; Baruch \& Goldstein 1999; Davis et al. 2000; Li \& Norland 2001). In this context, successful invaders often appear to make better use of high nutrient supply (Craine \& Lee 2003). By applying field manipulation of soil nutrient resources, e.g., Huenneke et al. (1990) were able show that the invasibility of serpentine grassland habitats by non-native annual grasses is probably a function of nutrient availability. They found that fertilization had a stronger effect on the above-ground biomass production of invaders than on native plants, whose response to the treatment was rather transient. In contrast, in their comparison between exotic and native plant species, Smith \& Knapp (2001) failed to provide evidence for considerable differences in morphological and physiological traits related to resource use efficiency. 
A crucial factor in our analysis for growth and seedling establishment was magnesium. This is amazing considering the base-poor substrates Rhododendron ponticum normally grows on (Cox 1979). However, there is evidence that the nutrient supply in Ireland is closely associated with the distance from the sea. We found a high correlation between magnesium contents in soil and latitudinal position of the respective site $\left(\mathrm{R}_{\mathrm{S}}=0.8286, \mathrm{p}=0.0416\right)$. Mg is known to originate from seawater; this suggests that a location near the sea in combination with westerly winds may provide additional nutrient input and, as a consequence, enhance nutrient supply in soils (Marschner 1995). Moreover, one has to keep in mind that the invasion of a successfully spreading exotic itself may promote alteration of the soils to its own benefit (Reinhart et al. 2003; Siemann \& Rogers 2003). The mobilization of cations by the production of polyphenols, for example, has been already suggested as a mechanism of rhododendron's spread (Cross 1975; Mitchell et al. 1997; Yu et al. 1999). The effects of exotic plant invasions on soil nutrient cycling processes were recently reviewed by Ehrenfeld (2003), who summarized both examples of changes in soil properties as a consequence of invasions and also examples of exotics with no such changes. However, the significant differences between native and invaded sites persist regardless of a putative species' effect on the soils and thus, provide support; for the hypothesis of more favourable edaphic conditions in the new area.

In addition to the relevance of opportune edaphic conditions, the hypothesis of suitable climatic conditions in the new territory applies in a similar manner. Despite clear differences between all three countries, we found a higher similarity between Irish and Georgian sites, particularly, with respect to low temperature parameters. According to this, it is improbable that the absence of cold winter temperatures or frequent frost events is of major importance for rhododendron invasion. It seems that the low annual temperature amplitude and the absence of extreme temperature maxima in the summer ensure that the rhododendron sites in Ireland are well supplied with water without the occurrence of summer drought periods. In contrast, at Spanish sites summer temperatures were undoubtedly important. The high mortality of our rhododendron transplants in Spain and the time of the plants' death were closely associated to the local drought episodes in early summer. These findings are consistent with former conclusions. Cross (1975) presumed that summer temperatures are probably more important than winter temperatures for the spread of Rhododendron ponticum. Mejías et al. (2002) hypothesized that drought episodes in the Mediterranean summer, in particular, are responsible for limited seedling establishment and growth in Spanish populations. Similarly, we found survivorship of transplants to be highest in Ireland and lowest in Spain. 


\section{Invasive genotypes}

As genetic differences are likely to play a major role in whether or not an invasion succeeds (Mack 1996; Williamson \& Fitter 1996), we expected to find superior invasive Irish genotypes across environments. Willis \& Blossey (1999), e.g., found strong evidences for genotype effects on growth parameters of Lythrum salicaria plants in both the native and invaded ranges exposed to the two environments. Their results suggested that plants from non-indigenous populations tended to be more vigorous than those originating from indigenous regions. Similarly, Bastlová \& Kvet (2002) could demonstrate in a greenhouse experiment that invasive populations of Lythrum salicaria grew taller than native populations due to differences in their dry weight allocation pattern. Surprisingly, our survivorship data of transplants were contrary to expectations, i.e. Irish individuals exhibited the lowest survival rates in all three countries. With respect to survival, we found the weakest genotypes among the Irish origins. As the present experiment was conducted with individuals reproduced vegetatively from cuttings, these findings may either be the outcome of experimentinherent difficulties in rooting success, but also due to specific traits of Irish rhododendron. Since clonality is not supposed to be a decisive factor in invasiveness of Rhododendron ponticum in Ireland (Erfmeier \& Bruelheide 2004a) but is frequently reported for native sites (Esen 2000; Mejías et al. 2002), it is possible that the Irish genotypes were less adapted to vegetative reproduction, including the production of adventitious roots, in the field than native provenances. In any case, in greenhouse experiments with seed material from native and invasive populations, we found clear evidences for invasive genotype effects with Irish plants having higher growth rates than Spanish and Georgian ones (unpublished data). This discrepancy can only be resolved by further transplantation experiments with seed material.

We found a close relationship between Irish and Spanish rhododendron plants that had been transplanted to Ireland. This is consistent with the results ofMilne \& Abbott (2000) who detected a mainly Iberian provenance of invasive rhododendron by restriction fragment length polymorphisms. This assumption confirms the appropriateness of the release hypothesis, at least for the Spanish rhododendrons, which seem to suffer from abiotic stress at their native sites. The weak relationship between Irish and Georgian rhododendron transplants also corresponds with the biometrical results for the adults. As Erfmeier \& Bruelheide (2004a) concluded, this weak relationship is probably due to genetic rather than environmental differences.

\section{Habitat-genotype interactions}

With respect to survivorship, the genotypes behaved differently in different environments. As we found no general trend across genotypes for superior performance in their respective home ranges, 
there is only limited evidence for local adaptation as a general pattern across the taxa investigated. Studies on the relevance of local adaptations in general (Fritsche \& Kaltz 2000; Montalvo \& Ellstrand 2000) and in the context of invasions (Rice \& Mack 1991; Williams et al. 1995; Parker et al. 2003) have shown no consistent pattern thus far. Galloway \& Fenster (2000) hypothesized that the scale of local adaptation reflects the scale of underlying environmental heterogeneity. Accordingly, they found little evidence for home-site advantages in an annual legume, except for the most widely separated sites. They concluded that there was relevance for local adaptation only on broader scales. Joshi et al. (2001) compared environmental and genetic effects on life history traits of three common species (Trifolium pratense, Dactylis glomerata and Plantago lanceolata) in a reciprocal transplant experiment on a European scale, and they detected clear evidence for homesite advantages of the respective provenances. The authors consequently hypothesized that local specialization might be a rule for the investigated widespread species. In any case, the absence of clear evidence for an adaptive value of Rhododendron ponticum might be due to experimental restrictions as we had no replication in time, and the expression of local adaptation, particularly for survival, is known to vary considerably from year to year (Rice \& Mack 1991).

Another factor that might apply for Rhododendron in the British Isles is the theory of adaptive plasticity as consequence of highly variable environmental conditions (see Sultan \& Spencer 2002), which might be reflected in the new range. High phenotypic or developmental plasticity as underlying a general-purpose genotype has often been presumed to be promoted by hybridization (Baker \& Stebbins 1965; Ellstrand \& Schierenbeck 2000; Parker et al. 2003). This has to be taken into consideration, particularly, as hybridization of Rhododendron ponticum with closely related North American species $R$. catawbiense and $R$. maximum has repeatedly been suggested before (Cox 1979; Milne \& Abbott 2000). In any case, the impact of plasticity for different Rhododendron ponticum genotypes has to be assessed experimentally in additional studies. However, in our greenhouse experiments, there was only little evidence for a higher plasticity in morphological and growth traits of the Irish genotypes (unpublished data).

\section{Conclusions}

None of the initially posted hypotheses can be rejected for Rhododendron ponticum. Accordingly, we have to conclude that all three factors-i.e. habitat, genotype and adaptation to the new environment-contribute to explaining the successful spread of the species in the British Isles, but they all support the hypotheses to a different degree. According to the degree of correlations and the magnitude of effects, the evaluation of each factor's contribution to the invasion success of Rhododendron ponticum leads to a ranking of decreasing importance from a most appropriate 
habitat that is susceptible to Rhododendron invasion, over the existence of an invasive genotype towards, finally, adaptation to the new environment.

\section{Acknowledgements}

The authors wish to thank Giorgi Nakhutsrishvili, Juan Arroyo and Gerry Doyle for their help in organizing fieldwork in Georgia, Spain and Ireland. Logistic help from Zurab Manvelidze (Georgia) and the staffs from Los Alconorcales Natural Park (Spain), Killarney National Park and Wicklow National Park (Ireland) is gratefully recognized. We thank Mathias Wegner for his help in conducting data collection in the field. We appreciate valuable collaboration with Christian Kluth for assistance with statistical analyses and for constructive discussions on the manuscript. This work was supported by a grant of the German Research Foundation ( $\mathrm{Br}$ 1698/3). 



\title{
Invasive and native Rhododendron ponticum populations: Is there evidence for genotypic differences in germination and growth?
}

\begin{abstract}
Previous studies have shown that the invasive spread of Rhododendron ponticum in the British Isles is influenced by the more favourable environmental conditions in the new territory than in the species' home range. In this study, we asked whether the species' invasion success might also involve a genotypic background for higher growth and germination rates in invasive populations. We tested the hypotheses that invasive populations have higher absolute germination rates, germinate faster and exhibit higher growth rates. We present data from greenhouse and climate chamber experiments with seed material and Rhododendron cuttings from six populations each of native Georgian, native Spanish and invasive Irish populations subjected to different temperature environments. There were no differences in the maximum germination rate and optimum germination temperature between native and invasive origins. We found significant differences in germination velocity with the Irish seeds responding most rapidly to all germination treatments. Accordingly, in the growth experiment the invasive Irish origins had the highest relative growth rates in all environments tested.

Our results provide evidence for a genetic shift in invasive populations towards an increased investment in growth and towards a faster germination rate. Both traits would contribute to explaining this species' range expansion. The underlying evolutionary mechanisms for this shift are discussed, including the possibility of hybridisation or of an ecological release from hitherto experienced constraints in the native area.
\end{abstract}

\section{Introduction}

Many studies on the invasion biology of plant species have emphasised the promoting impact of favourable traits for a species' successful spatial expansion (Baker \& Stebbins 1965; Baker 1974; Mack 1996; Williamson \& Fitter 1996). In particular, characteristics associated with reproduction and rapid growth have been the focus of numerous studies (Rejmánek \& Richardson 1996; Willis et al. 1999; Bastlová \& Kvet 2002; Jakobs et al. 2004). In a recent review, Kolar \& Lodge (2001) found that, primarily, high reproduction rates, vegetative reproduction, early maturation, a short juvenile period and seed mass are positively linked to invasiveness. 
With the current increase in the level of awareness, invasion ecologists have realised that the search for the general validity of this approach — which was originally intended to allow the prediction of invasions-has proven to be hardly successful and will probably remain unsatisfactory (Noble 1989; Thompson 1991; Perrins et al. 1992; Perrins et al. 1993; Williamson 1999; Radford \& Cousens 2000). The current state of knowledge suggests that the reasons for a species' invasion success have to be seen as a synthesis of various factors, such as genotypic traits, habitat characteristics, community effects including reduced competition intensity or the absence of enemies, and specific interactions among these factors (Radford \& Cousens 2000; Alpert et al. 2000; Klironomos 2002; Milbau et al. 2003). In consequence, a species-specific explanation may well be more promising than a general all-purpose explanation.

It is the intention of this study to assess the genotypic contribution to the invasiveness of Rhododendron ponticum L. Rhododendron ponticum is an evergreen shrub of the Ericaceae family that is successfully spreading throughout Atlantic Western Europe with economically destructive impact in its new range. Invasive populations are regarded as a common threat to natural ecosystems, especially in the British Isles (Cross 1981; Crawley 1987). Despite a clear evidence for a benign environment favouring the spread of Rhododendron ponticum (Erfmeier \& Bruelheide 2004b), there is reason to believe that specific genetic traits of germination and growth rates are involved in explaining the species' success in the British Isles. In a comparative field study of invasive Irish and native Spanish and Georgian populations, Erfmeier \& Bruelheide (2004a) found higher seedling occurrences and higher annual increases in shoot length in the invaded area than in the native habitats.

Successful plant invasions have often been attributed to effective reproduction (Burke \& Grime 1996; Radford \& Cousens 2000; Grigulis et al. 2001). For example, in a study of 24 frequently cultivated pine species, Rejmánek \& Richardson (1996) demonstrated that early and consistent reproduction and rapid population growth are positively correlated with successful invasions. For weedy species, Brändle et al. (2003) found a general relationship between the germination niche breadth and distributional range size. Apart from the absolute level of germination rates, a population's ability of rapid germination - as soon as the environment offers suitable conditions for germination - can also be favourable. In a comparative study on the germination patterns of 403 species in the Sheffield region, Grime et al. (1981) detected a positive correlation between the species' capacity for immediate germination and species-abundance in the local flora. Furthermore, they found indications of a positive relationship between the rate of germination and the relative growth rate of the seedling. 
Apart from between-species differences in germination patterns, differences in germination traits at the within-species level also exist. Without doubt, germination patterns are influenced by a multitude of interactions among seed characteristics and environmental variables. In this context, the genetic nature of seeds has to be considered. In their study on the genetic effects of germination timing and environment in the desert mustard Lesquerella fendleri, Cabin et al. (1997) provided evidence showing that the genetic constitution of seeds plays a significant role in regulating the timing and the success of germination. In a two-factorial experiment of early- and late-germinating genotypes subjected to two different environments they found that allele frequencies varied significantly with both germination timing and environmental treatment. However, the adaptive value of differences in germination timing remain unclear in their study.

For many invasive plant species, rapid growth has similarly been shown to be of relevance by experimental approaches (Pattison et al. 1998). Grotkoop et al. (2002) found relative growth rates of pine species to be positively correlated with a calculated measure of invasiveness. In a 14-year common garden experiment, Siemann \& Rogers (2001) were able to demonstrate a genetic basis for a more vigorous growth of invasive Sapium sebiferum genotypes than of native provenances from Asia.

Although there is no question that characteristics differ among genotypes, the study of the underlying mechanisms explaining how these genotypes evolved has resulted in two controversially discussed concepts (Parker et al. 2003): invasiveness as innate superiority due to previous evolution in competitive environments (Callaway \& Aschehough 2000), or as adaptation resulting in the evolution of post-invasion genetic differences (Mack et al. 2000; Leger \& Rice 2003), possibly as a consequence of the escape from enemies (Blossey \& Nötzold 1995; Maron \& Vilà 2001; Keane \& Crawley 2002).

Adaptations to specific environments may also be important for growth rates. For Rhododendron ponticum, the evidence of a climatic impact also exists. Erfmeier \& Bruelheide (2004b) found negative correlations between the vegetative growth rates of Rhododendron ponticum and the microclimatic temperature conditions in the three countries of origin. The authors assumed a low annual temperature amplitude in the new range and the absence of extreme temperature maxima in the summer to have a positive impact on the growth of the plants, and they assumed that a release from climatic constraints applies for Rhododendron ponticum. Rapid growth might then be interpreted as adaptation to altered environmental conditions.

Leger \& Rice (2003) pointed out that the distinction between environmentally induced phenotypic differences and a genetic change can be revealed by common garden experiments including both 
native and invasive individuals grown together in the same environment. Comparing size and fecundity of 20 native and invasive Californian poppies (Eschscholzia californica), they found indications for a genetic shift in traits towards rapid growth and reproduction in different environments, and thus for an evolutionary context of loss of traits.

Our previous results from field studies in Georgia, Spain and Ireland showed that germination and vegetative growth differed among the countries (Erfmeier \& Bruelheide 2004a,b). With a median of 1.4 and 2.6 seedlings per $\mathrm{m}^{2}$ for the years 2000 and 2001, seedling establishment in both years was more successful in the new territory than in the native ones, where the median indicated no seedling occurrence in the field. With the present study, we thus intend to provide evidence corroborating the theory that differences exist in germination pattern and growth rates between native and invasive Rhododendron populations and to provide evidence for a genetic background of the invasive response in the field.

In this paper, we present germination and growth experiments with Rhododendron ponticum seeds and cuttings exposed to different temperature treatments, with the objective of testing the following hypotheses: 1) The invasive Rhododendron populations have higher absolute germination rates, thus explaining the observed pattern of more seedlings per unit area in Ireland. 2) In accordance with the assumption of rapid responses, we expected that seeds from the invasive populations would germinate faster. Analogously, 3) it is assumed that growth rates of the invasive Rhododendron reach higher values than plants from the native origins.

\section{Material and methods}

\section{Study species}

Rhododendron ponticum L. is an erect, evergreen Ericaceae shrub that reaches a height of 2 to $8 \mathrm{~m}$ (Tutin et al. 1972). In accordance with the species' disjunctive distribution (along the Black Sea coast, in Lebanon and on the Iberian Penisula), two subspecies are currently recognised: plants in Turkey and in Georgia in the Caucasus area are typically attributed to the subspecies ponticum; whereas occurrences from Southern Spain and Portugal are taxonomically assigned to ssp. baeticum (Boiss. \& Reuter) Hand.-Mazz. (Tutin et al. 1972; Clapham et al. 1987; Castroviejo et al. 1993). In the Caucasus region, $R$. ponticum ssp. ponticum populations are associated with deciduous summergreen mixed and beech forest communities ranging from lowlands up to the timberline at 1900 m a.s.l.; whilst the Iberian occurrences are a component of mediterranean sclerophyllous forests and can be found primarily along creeks, or as a scrubland element of humid mountain ranges (Mejías et al. 2002). Their altitudinal distribution ranges from 400 to $1200 \mathrm{~m}$ a.s.l. 
The introduction of this species to the British Isles was reported for the year 1763 (Elton 1958). Since that time, the species has been repeatedly introduced to Great Britain and Ireland, where it has already invaded a large variety of natural communities, such as forests, heathlands and bogs.

Clonal spreading of Rhododendron ponticum is reported to be a successful mechanism of propagation (Mejías et al. 2002), but it appears to be of minor importance for local spreading in the British Isles (Cross 1975; Shaw 1984). In their new territory, in particular, sexual reproduction by means of numerous small wind-dispersed seeds is extremely effective (Erfmeier \& Bruelheide 2004a). Seed size differs according to taxonomical and geographical assignment: with $2 \mathrm{~mm}$ for plants of the ssp. ponticum (Davis 1978), 0.4 - $0.8 \mathrm{~mm}$ for Iberian seeds of the subspecies baeticum (Castroviejo et al. 1993), and with an intermediate length in British seed material (1.5 mm; Cross 1975). Germination in the new area occurs on many substrates, and light is essential for the germination of Rhododendron ponticum seeds (Cross 1975). Mature seeds, in general, do not need any further pre-treatment and will germinate immediately when exposed to appropriate environmental conditions. Rhododendron ponticum is classified as having a transient seed bank, i.e. its seeds persist in the soil for less than one year (Thompson et al. 1997). Optimum germination temperatures of closely related Rhododendron taxa are specified to be relatively high (e.g. $23^{\circ} \mathrm{C}$ for R. ferrugineum and $26 / 21^{\circ} \mathrm{C}$ for R. maximum; Baskin \& Baskin 1998). Moreover, these species are described as non-dormant and thus do not require any cold stratification (Baskin \& Baskin 1998).

\section{Experimental material and sampling design}

For both experiments we used plant material that was obtained from six native populations each in Georgia and in Spain, and from six invasive populations in Ireland. Populations were selected randomly across an area exhibiting maximum altitudinal and geographical habitat variability in each country. To ensure comparability between the countries, we chose only forest populations with a northern aspect and a slope of $10^{\circ}$ to $20^{\circ}$. For further details concerning selection modus, location and characteristics of the populations see Erfmeier \& Bruelheide (2004a).

\section{Germination experiment}

For each population of Rhododendron ponticum, freshly matured seeds of the three origins were collected in November 1999 in Georgia, in January 2000 in Spain and in February 2000 in Ireland by harvesting entire, naturally pollinated racemes from at least each 20 individuals per population. Seeds from all these plants were thoroughly mixed within a population's samples to minimise the effects of single individuals, and then stored in a dark, dry repository at $10^{\circ} \mathrm{C}$ for six months until use. In all germination experiments, seeds of each population were separated into two size- 
dependent fractions, and only seeds from the large-seed fraction were chosen at random from the pooled sample.

Germination tests for each population were carried out in petri dishes with 20 seeds from each of the 18 populations. Seeds were placed on filter paper discs having a diameter of $90 \mathrm{~mm}$ (Schleicher \& Schüll) covering a layer of $80 \mathrm{ml}$ of sterilised sand, which served as a water reservoir. All dishes were watered every second day with de-ionised water and sprayed with $50 \%$ ethanol solution once a week to avoid infection by mildew. The seeds were subjected to four different temperature treatments. Each population was replicated five times at each temperature level, and the dishes were arranged randomly in climate chambers. The dishes were placed in a controlled environment cabinet (Heraeus Vötsch) with a daily alternating temperature regime of $2 / 12^{\circ} \mathrm{C}, 9 / 19^{\circ} \mathrm{C}, 16 / 26^{\circ} \mathrm{C}$ and $23 / 33^{\circ} \mathrm{C}$ and a thermo- and photoperiod of 12 hours. The temperatures were chosen to simulate mean daily maximum and minimum temperatures near the soil surface during the growing season both in the native and in the invaded areas. The cabinets were equipped with white light providing $40 \mu \mathrm{E} \mathrm{m} \mathrm{m}^{-2} \mathrm{~s}^{-1}$ at seed level. Preliminary tests of light demands for germination showed no significant

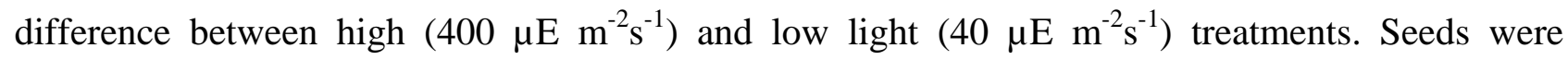
considered to have germinated when the first radicle emerged. The minimum duration of the test was 107 days, and the weekly census continued until no further germination was recorded for two weeks. Germination was monitored for a total of 24 weeks.

\section{Growth experiment}

In the autumn/winter of 1999/2000, cuttings of Rhododendron branches were collected randomly — and in parallel to the seed material — from different individuals in each of the six populations per country. Harvesting of 150 samples per population was performed by cutting branches with a length of $40 \mathrm{~cm}$ and at least three internode sections, which show the increase of the three previous years and with evidence of lignification at the cut surfaces. All cuttings were brought into the greenhouse in Goettingen, Germany, where they were planted onto breeding boards into a 70\%:30\% sand-peat substrate to re-grow roots.

In February 2001, these individuals were planted into 1.51 pots and the best-developed individuals, i.e. those that had successfully developed roots, were chosen for the growth experiment. The plants were placed into controlled greenhouse cabinets subjected to a daily alternating temperature regime of either $7 / 13^{\circ} \mathrm{C}, 13 / 18^{\circ} \mathrm{C}$ and $18 / 23^{\circ} \mathrm{C}$ and a thermo- and photoperiod of 8/16 (night/day) hours. The three temperature regimes were chosen to approximate the monthly mean temperatures during the growing season both in the native and the invaded areas (see Erfmeier \& Bruelheide 2004b). Light intensity was adjusted to $200 \mu \mathrm{E} \mathrm{m}^{-2} \mathrm{~s}^{-1}$ at plant level in all cabinets by artificial illumination. 
In addition, all plants received external light, which changed in the course of the experiment according to the ambient seasonal lengths of daylight periods. Cabinet humidity was set at constant $80 \%$ relative humidity. All pots were watered every second day and fertilised fortnightly during the growth period with an $0.05 \%$ NPK fertiliser (Flory 1, Euflor).

Since rooting success was different depending on the plants' origins (with survivorship ratios of 38.3\%, 51.4\% and 10.6\% for Georgian, Spanish and Irish cuttings, respectively), the assignment of replicates to the temperature treatments was unequal across the three origins each yielding $n=6$ populations for the plants of Georgian and the Spanish origins, and $n=2$ for those of Irish origin.

The experiment was begun in April 2001 and monitored until September 2002. Measurements of growth parameters (increase in total shoot length and number of leaves), growth strategy traits (number of branches and internodes), as well as leaf morphology parameters (size and shape of leaves) were made in June, July, August and September 2001 and again in March, May, July and September 2002. For parameters of increase, we calculated both absolute (AGR) and relative (RGR) growth rates. Shape of leaves was defined as length from leaf base to greatest width divided by total leaf length.

\section{Statistical analysis}

\section{Germination experiment}

All germination parameters were tested for normal distribution (proc univariate, Shapiro-Wilk statistics; SAS Institute 2000). Since most of the germination data required transformation prior to analysis, we used non-parametric statistics by transforming data into ranks (proc rank, SAS Institute 2000; for appropriateness of rank transformation see Brunner \& Puri 2001). Analyses were performed by applying a two-factorial nested ANOVA design with the fixed factors 'country' and 'temperature' (temp). Populations were nested within countries (pop(country)) and treated as random (proc glm; SAS Institute 2000). Post-hoc tests were realised with Ryan-Einot-GabrielWelsh (REGWQ) multiple range tests.

To include the temporal development of germination patterns in the analyses, we fitted the data to a model using regression procedures. To compare time (days) elapsed to $10 \%, 50 \%$ and $90 \%$ of maximum germination, the germination rates were related to the maximum percentage of seeds that germinated in a given population*temperature combination for each dish. In consequence, the data exhibited values between 0 and 1 for each dish. The data were then fitted to a logistic regression model (proc nlin, SAS Institute 2000): 


$$
R G=\frac{e^{\left(a+b^{*} t\right)}}{1+e^{\left(a+b^{*} t\right)}}
$$

$R G$ = Relative germination, i.e. absolute germination related to maximum germination;

$a, b=$ estimated constants;

$t \quad=$ time [days].

A test for the goodness of fit was provided by calculating the Pearson correlation coefficient between predicted and observed values (proc corr, SAS Institute 2000). For the temperature levels $2 / 12^{\circ} \mathrm{C}, 9 / 19^{\circ} \mathrm{C}, 16 / 26^{\circ} \mathrm{C}$ and $23 / 33^{\circ} \mathrm{C}$, the worst coefficient was $0.885,0.938,0.935$ and 0.927 , respectively. Time (days) elapsed to $10 \%, 50 \%$ and $90 \%$ of germination was calculated for each dish and subjected to a two-factorial nested ANOVA as described above.

Illustration of modelled data for the Georgian origin at the lowest temperature level was rejected because more than $75 \%$ of the Georgian dishes still had not germinated at the end of the experiment. Nevertheless, statistical analyses were realisable for Georgian samples, due to the fact that rank transformed data were used. When assigning ranks of modelled data of time (days) elapsed to $10 \%, 50 \%$ and $90 \%$ of maximum germination the dishes with no germination were assigned to the highest ranks.

\section{Growth experiment}

To achieve normality of distribution, all data were transformed into ranks. The transformed data were then subjected to a two-factorial nested ANOVA as described above (proc glm; SAS Institute 2000). The pre-experimental plant size was included as a covariate in the statistical models to correct for plant size differences. The covariate was only kept in the model if it demonstrated a significant covariate effect; otherwise, the model was implemented without including the covariate. Post-hoc tests were realised with Ryan-Einot-Gabriel-Welsh test.

\section{Results}

\section{Germination responses}

After 14 weeks of treatment exposure, germination of Rhododendron ponticum seeds was strongly affected by temperature (main effect) (Table 1). With a median cumulative germination rate of 76.5\%, 70.0\% and 76.0\% for Georgian, Spanish and Irish populations, respectively, the rates were consistently highest at the temperature level of $16 / 26^{\circ} \mathrm{C}$ (Fig. 1). The magnitude of germination was high at a broad range of temperatures, but all temperature levels differed significantly from each other with lowest germination responses at the coldest level of $2 / 12^{\circ} \mathrm{C}$. 
Table 1: Analysis of variance for germination rates of Rhododendron ponticum seeds after 14 weeks of temperature treatment. Data were transformed into ranks. ANOVA was performed with populations as random factor nested within country at five replicates per population $(\mathrm{N}=360)$.

\begin{tabular}{lrcrrr}
\hline Source of variation & d.f. & Sum of squares & Mean squares & F & P \\
\hline Temp & 3 & 2293558 & 764519 & 258.64 & $<0.0001$ \\
Temp*country & 6 & 73750 & 12292 & 4.16 & 0.0005 \\
Pop (country) & 15 & 425163 & 28344 & 9.59 & $<0.0001$ \\
Error & 333 & 984312 & & & 0.61 \\
Country & 2 & 91322 & 45661 & & 0.2324 \\
Error (pop(country)) & 15 & 425163 & & & \\
\hline
\end{tabular}

Although germination rates of the populations of invasive origins were consistently among the highest, we found no main effect difference between native and invasive origins in their response towards temperature treatment. Correspondingly, there was no significant difference among the origins in the demands on temperature for optimum germination. The median optimum temperature was 25.2 C, 24.3 C and 24.9 C for the Georgian, the Spanish and the Irish origins, respectively $\left(F_{2,15}=0.57, p=0.5762\right)$. There was a large variation among populations within country indicated by significant effects of populations nested within countries. This applies particularly for the Georgian origins with a large within-country variability.

In addition to these general pattern in germination behaviour, we detected significant origin interactions with temperature (Table 1). The native Georgian origins responded more sensibly with higher germination losses at the highest temperature level (Fig. 1).

Analysis of variance detected significant differences in germination speed (Fig. 2). Velocity of germination responses differed across the temperature levels (main effect) with fastest germination progression at $16 / 26^{\circ} \mathrm{C}$ and slowest response at the coldest temperatures. For the elapsed time to $10 \%, 50 \%$ and $90 \%$ of maximum germination, we found significant differences among the origins (Table 2). The invasive populations required significantly less days to reach the $10 \%$ and $50 \%$ levels of germination than the native provenances. For the higher level of $90 \%$ of maximum

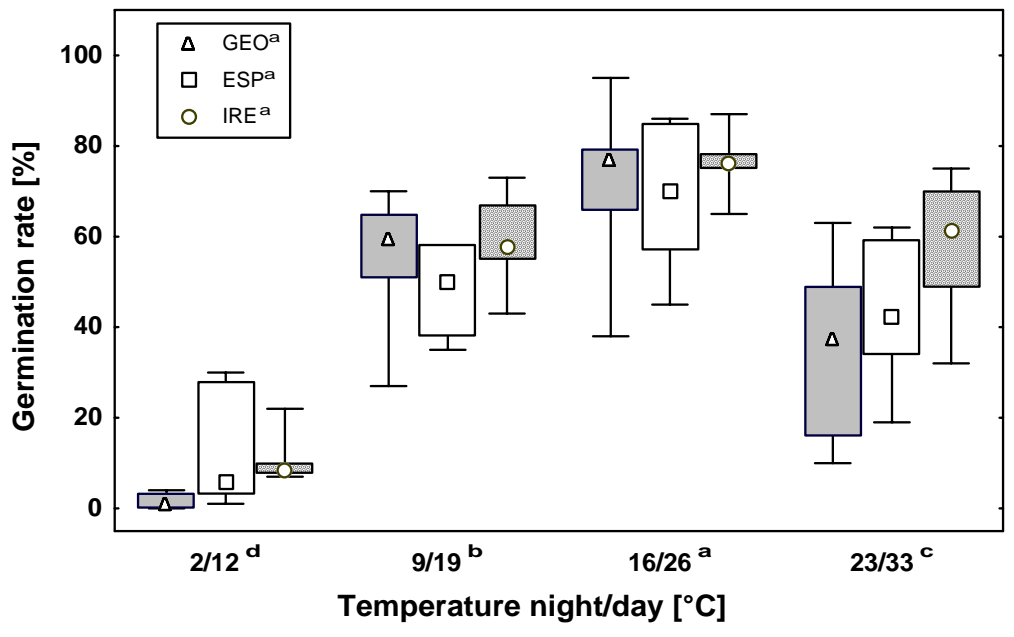

Fig. 1: Germination rates of Rhododendron ponticum seeds across four temperature regimes $(\mathrm{n}=360)$. Medians, quartiles, minimum and maximum refer to population means $(n=5)$. Different letters indicate significant differences according to the REGWQ-test. $\mathrm{P}<0.0001$. For statistical details referring to rank transformed data see Table 1. 
Table 2: Analysis of variance for the elapsed time to $10 \%, 50 \%$ and $90 \%$ of final germination of Rhododendron ponticum. Data were transformed into ranks. ANOVA was performed with populations as random factor nested within country and five replicates each $(\mathrm{N}=360)$. $\mathrm{G}=$ Georgia, $\mathrm{E}=$ Spain, $\mathrm{I}=$ Ireland. Different letters indicate significant differences for the origin effects (country) according to the REGWQ test.

\begin{tabular}{|c|c|c|c|c|c|c|c|c|c|}
\hline Parameter & Source of variation & d.f. & $\begin{array}{c}\text { Sum of } \\
\text { squares }\end{array}$ & Mean squares & $F$ & $\bar{P}$ & $\overline{\mathbf{G}}$ & $\bar{E}$ & $I$ \\
\hline \multirow{6}{*}{$10 \%$ germination } & Temp & 3 & 3170009 & 1056670 & 790.82 & $<0.0001$ & & & \\
\hline & Temp*country & 6 & 83394 & 13899 & 10.4 & $<0.0001$ & & & \\
\hline & Pop (country) & 15 & 35489 & 2366 & 1.77 & 0.0375 & & & \\
\hline & Error & 333 & 444947 & 1336 & & & & & \\
\hline & Country & 2 & 142932 & 71466 & 30.21 & $<0.0001$ & $a$ & b & c \\
\hline & Error (pop(country)) & 15 & 35489 & 2366 & & & & & \\
\hline \multirow[t]{6}{*}{$50 \%$ germination } & Temp & 3 & 3322183 & 1107394 & 1231.7 & $<0.0001$ & & & \\
\hline & Temp*country & 6 & 31271 & 5212 & 5.8 & $<0.0001$ & & & \\
\hline & Pop (country) & 15 & 68189 & 4546 & 5.06 & $<0.0001$ & & & \\
\hline & Error & 333 & 299393 & 899 & & & & & \\
\hline & Country & 2 & 155736 & 77868 & 17.13 & 0.0001 & $a$ & b & c \\
\hline & Error (pop(country)) & 15 & 68189 & 4546 & & & & & \\
\hline \multirow[t]{6}{*}{$90 \%$ germination } & Temp & 3 & 3209986 & 1069995 & 870.69 & $<0.0001$ & & & \\
\hline & Temp*country & 6 & 18209 & 3035 & 2.47 & 0.0238 & & & \\
\hline & Pop (country) & 15 & 88361 & 5891 & 4.79 & $<0.0001$ & & & \\
\hline & Error & 333 & 409224 & 1229 & & & & & \\
\hline & Country & 2 & 150992 & 75496 & 12.82 & 0.0006 & $\mathrm{a}$ & $\mathrm{b}$ & $\mathrm{b}$ \\
\hline & Error (pop(country)) & 15 & 88361 & 5891 & & & & & \\
\hline
\end{tabular}

germination, the native Spanish genotypes managed to compensate for the Irish head start, but the difference to the slower Georgian origins still remained existent. For all investigated levels, we detected significant temperature-country interactions, i.e. the origins behaved differently depending on the temperature. This is primarily due to a clearly retarded germination of the native Georgian genotypes compared to the invasive Irish ones at the highest and lowest temperatures (Fig. 2 D).

\section{Growth responses}

There were significant temperature effects with the highest growth responses at the highest temperature for most of the parameters (Table 3, Fig. 3). We additionally found significant differences for the main effect country: the absolute growth rates of both increase in shoot length and in number of leaves were significantly higher for the Spanish and Irish genotypes than for the Georgian ones (Fig 3 A, B). For relative growth rates of the shoot length, the response of the invasive Irish genotypes differed significantly from both the native Spanish and Georgian genotypes (Table 3). For RGR, we found a significant effect of the covariate, i.e. the pre-experimental plant size affected RGRs of the plants.

We detected significant interactions between the main factors temperature and country for the tested parameters AGR of shoot length, and both AGR and RGR of number of leaves. This pattern is primarily due to the strong response of the native Spanish genotypes and the weak response of the Georgian genotypes at the warmest temperature treatment; whereas the magnitude of the invasive Irish responses was consistently high at all temperature levels. 

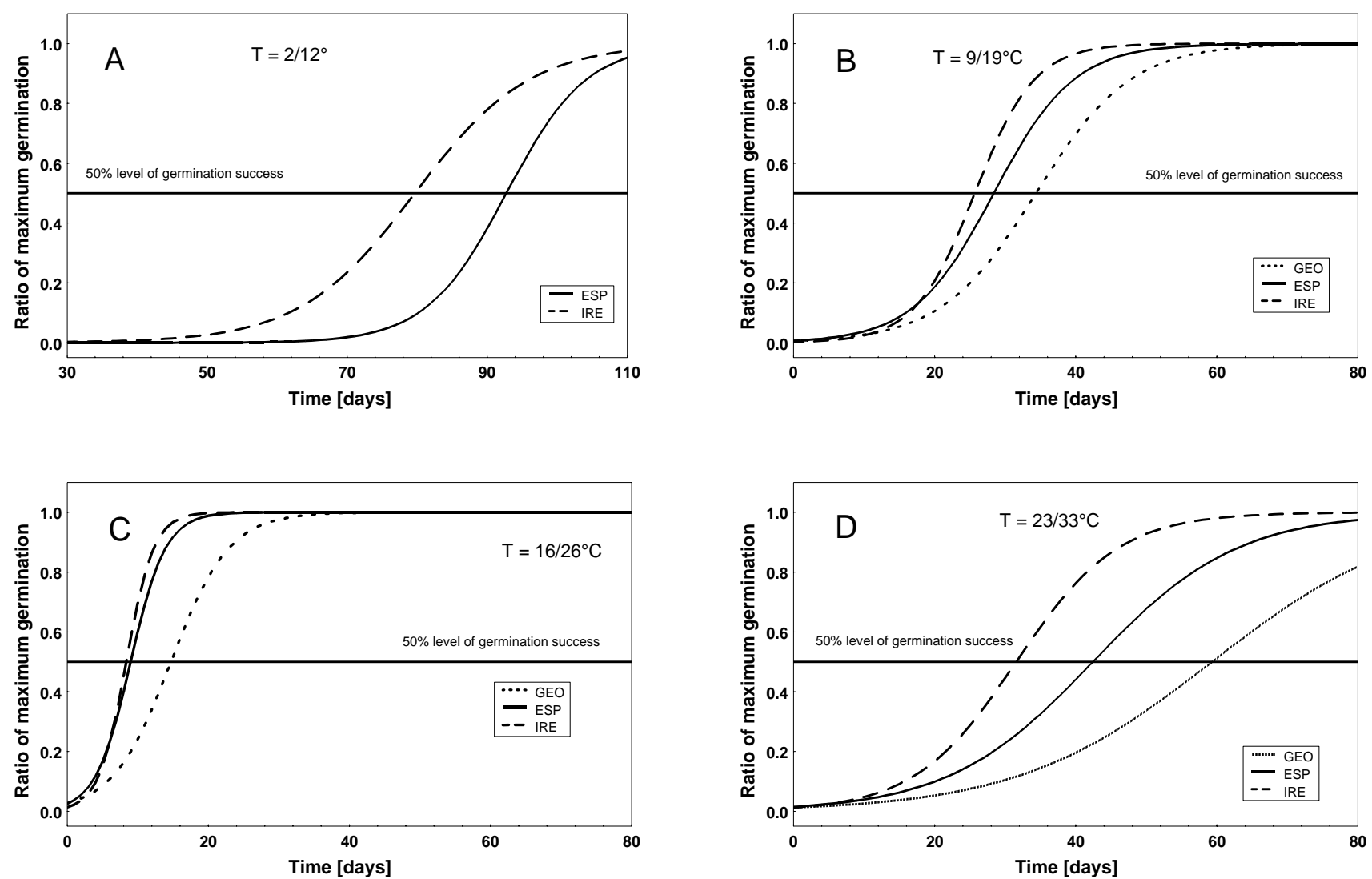

Fig. 2: Germination progress of Rhododendron ponticum seeds across four temperature regimes (each $\mathrm{n}=90$ ): A) $2 / 12^{\circ} \mathrm{C}$, B) $9 / 19^{\circ} \mathrm{C}, \mathrm{C}$ ) $16 / 26^{\circ} \mathrm{C}$, D) $23 / 33^{\circ} \mathrm{C}$. Germination development modelled by logistic regression (for details see methods chapter). $\mathrm{P}<0.0001$. For statistical details referring to rank transformed data see Table 2 . GEO = Georgia, $\mathrm{ESP}=$ Spain, IRE = Ireland .

Traits of growth strategies were thus affected by temperature (Table 3): both number of branches and number of internodes increased with increasing temperature. For both parameters, the genotypes differed significantly with highest numbers of branches and internodes within the Spanish origins; whereas the Irish genotypes responded with a lower number (Fig. 4). Interactions between temperature and country were only detected for the branching behaviour, with a stronger ramification of the Spanish genotypes at high temperatures.

For most of the leaf morphology parameters, we found no significant treatment effect. Length-width ratio and shape of leaves were the only traits that were affected by temperature and origin. Shape of leaves was significantly larger at low temperatures and significantly larger for Georgian leaves (temp $\mathrm{F}_{2,240}=4.04, \mathrm{p}=0.0187$; country $\mathrm{F}_{2,21.4}=8.47, \mathrm{p}=0.002$ ). With decreasing temperatures the length of the leaves was larger in relation to the leaves' width, and the leaves of invasive genotypes had a higher length-width ratio than native Georgian genotypes (temp $F_{2,240}=9.86, p<0.0001$; country $\mathrm{F}_{2,15.0}=3.94, \mathrm{p}=0.0423$ ). For both leaf parameters, the covariate exerted no significant effect. 

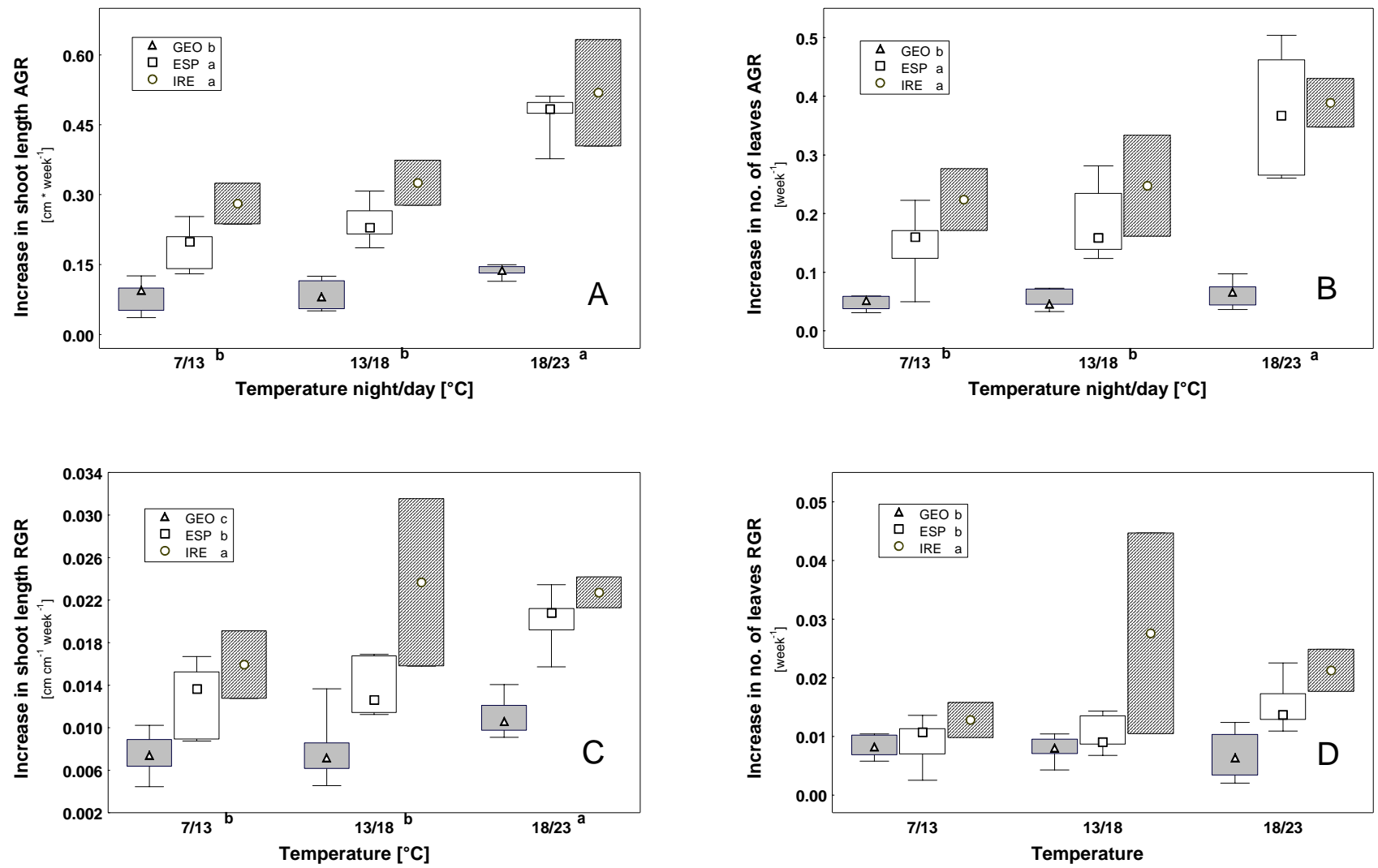

Fig. 3: Growth rates of Rhododendron ponticum across four temperature regimes: A) Increase in shoot length - Absolute growth rates (AGR), B) Increase in no. of leaves - Absolute growth rates (AGR), C) Increase in shoot length - Relative growth rates (RGR), D) Increase in no. of leaves - Relative growth rates (RGR). Medians, quartiles, minimum and maximum refer to population means ( $n=6$ for Georgia and Spain, $n=2$ for Ireland). Different letters indicate significant differences according to the REGWQ-test. For statistical details referring to rank transformed data see Table 3.
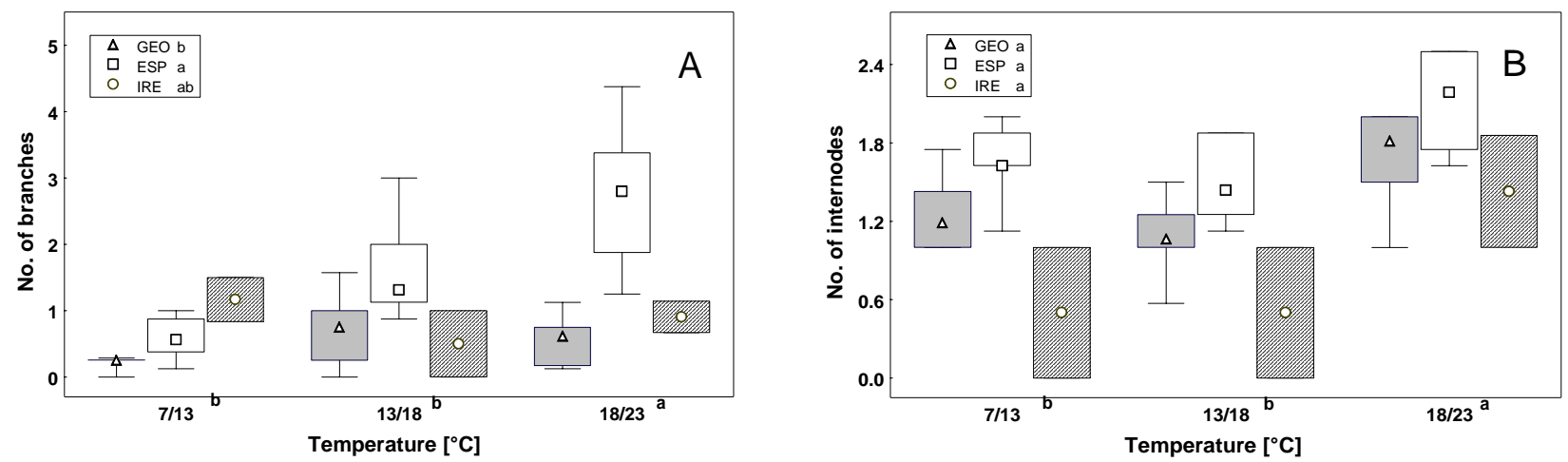

Fig. 4: A) No. of branches and B) No. of internodes of Rhododendron ponticum across four temperature regimes: Medians, quartiles, minimum and maximum refer to population means ( $n=6$ for Georgia and Spain, $n=2$ for Ireland). Different letters indicate significant differences according to the REGWQ-test. For statistical details referring to rank transformed data see Table 3 . 
Table 3: Analysis of variance for effects of temperature and origin on growth parameters of Rhododendron ponticum. The covariate (pretreatment size of individuals) was only considered in the model if significant. Data were transformed into ranks. ANOVA was performed with populations seen as a random factor nested within country. $\mathrm{G}=\mathrm{Georgia}, \mathrm{E}=$ Spain, I = Ireland. Different letters indicate significant differences for the origin effects (country) according to the REGWQ test.

\begin{tabular}{|c|c|c|c|c|c|c|c|c|c|c|c|c|}
\hline \multirow[b]{2}{*}{ Source of variation } & \multicolumn{4}{|c|}{ Increase in shoot length AGR } & \multicolumn{4}{|c|}{ Increase in no. of leaves AGR } & \multicolumn{4}{|c|}{ No. of branches } \\
\hline & d.f. & $\mathbf{F}$ & $\mathbf{P}$ & G E I & d.f. & $\mathbf{F}$ & $\mathbf{P}$ & G E I & d.f. & $\mathbf{F}$ & $\mathbf{P}$ & G E I \\
\hline Temp & 2 & 10.6 & $<0.0001$ & & 2 & 8.0 & 0.0004 & & 2 & 3.7 & 0.0272 & \\
\hline Temp*country & 4 & 4.3 & 0.0022 & & 4 & 4.7 & 0.0011 & & 4 & 3.9 & 0.0042 & \\
\hline Pop(country) & 11 & 0.9 & 0.5871 & & 11 & 2.3 & 0.0116 & & 11 & 1.2 & 0.2643 & \\
\hline Error & 254 & & & & 254 & & & & 254 & & & \\
\hline Country & 2 & 98.8 & $<0.0001$ & $\mathrm{~b}$ a $\mathrm{a}$ & 2 & 53.4 & $<0.0001$ & b a $a$ & 2 & 12.2 & 0.0004 & $b \quad a \quad a b$ \\
\hline \multirow[t]{2}{*}{ Error (pop(country)) } & 22.9 & & & & 15.0 & & & & 18.8 & & & \\
\hline & \multicolumn{4}{|c|}{ Increase in shoot length RGR } & \multicolumn{4}{|c|}{ Increase in no. of leaves RGR } & \multicolumn{4}{|c|}{ No. of internodes } \\
\hline Source of variation & d.f. & $\mathbf{F}$ & $\mathbf{P}$ & G E I & d.f. & $\mathbf{F}$ & $\mathbf{P}$ & G E I & d.f. & $\mathbf{F}$ & $\mathbf{P}$ & G E I \\
\hline Temp & 2 & 5.6 & 0.0044 & & 2 & 2.7 & 0.0684 & & 2 & 7.3 & 0.0008 & \\
\hline Temp*country & 4 & 2.1 & 0.0792 & & 4 & 2.7 & 0.0332 & & 4 & 0.1 & 0.9804 & \\
\hline Covar & 1 & 27.7 & $<0.0001$ & & 1 & 19.8 & $<0.0001$ & & 1 & 4.0 & 0.0475 & \\
\hline Pop(country) & 11 & 1.0 & 0.4131 & & 11 & 1.6 & 0.1104 & & 11 & 1.7 & 0.0813 & \\
\hline Error & 253 & & & & 252 & & & & 252 & & & \\
\hline Country & 2 & 48.2 & $<0.0001$ & $c \mathrm{~b} a$ & 2 & 7.9 & 0.0032 & $b \quad b \quad a$ & 2 & 8.1 & 0.0028 & a a $a$ \\
\hline Error (pop(country)) & 23.6 & & & & 18.9 & & & & 19.1 & & & \\
\hline
\end{tabular}

\section{Discussion}

The most striking result of this study was the consistent pattern that invasive Rhododendron ponticum were characterised by rapid responses and high absolute germination and growth rates independently of the tested environment. Nevertheless, overall, a distinction between native and invasive origins is to a lesser extent due to differences in the absolute height of the responses than due to the ability of an immediate reaction.

\section{Germination rates}

For the germination success we found no differences in the genetic constitution of the origins, and, consequently, no evidence for a higher germinability of invasive Rhododendron populations. In many plant species, high germination rates have been identified to be associated with the invasion success (Radford and Cousens 2000), but the contrary also applies. For example, the attempt to explain invasiveness in phylogenetically closely related species of the genus group Atriplex in terms of germination requirements was only partly successful: comparing two pairs each of invasive and non-invasive species of two sections of the genus, Mandák (2003) found that one species pair confirmed the hypothesis that germinability contributes to explaining the invasion success; while the other pair did not. In a comparison of eight perennial grass species, Milbau et al. (2003) 
searched for evident traits of invasiveness and invasibility, and found some "invasive" species to be characterised by high germination rates, whilst others were not.

Germination rates of Rhododendron ponticum seeds were comparable across all provenances, and the optimum temperature for germination was similarly high for Georgian, Spanish and Irish genotypes; whereas the temperature conditions the plants normally experience in the three countries differ remarkably between the invaded and the native area (Erfmeier \& Bruelheide 2004b). Thus, we found no evidence for a specific adaptation of germinability to regional temperature conditions. Mejías et al. (2002) found germination rates of approximately 45\% after 33 days of illumination treatment at $25^{\circ} \mathrm{C}$ for two Spanish populations, which are partly identical with those in our study. The current germination rates in our study for those Spanish populations were at $82 \%$ after 35 days of temperature treatment at $16 / 26^{\circ} \mathrm{C}$ and thus were approximately twice as high. This difference can be attributed to interannual variabilities in germination responses (Meyer \& Allen 1999), but it is more probably due to methodical differences in handling the seed material, e.g. the effect of our pre-selection of large-size fraction seeds. However, the potential to yield high germination rates across a wide range of temperature regimes — which we could demonstrate in this study — can be assessed as a suitable precondition for effective reproduction and invasion in the sense of Baker's general purpose genotype (Baker 1974).

\section{Germination velocity}

Our results confirm the hypothesis that invasive seeds responded most rapidly to the treatments. We can, thus, confirm that the velocity of germination is a genetic trait that is involved in the invasion success of Rhododendron ponticum. The promoting impact of rapid responses has frequently been attributed to successful plant invasion examples. In their two-year experimental study on plant community invasibility in Derbyshire, United Kingdom, Burke \& Grime (1996) concluded that, in particular, the combination of the ability to germinate at low temperatures at different light levels and the ability to germinate rapidly has to be considered as favourable. The authors assumed that early germination would be advantageous in a situation involving interspecific competition among seedlings. In any case, a repeated analysis after 5 years of continued experimental treatment did not confirm any such effect (Thompson et al. 2001). Nevertheless, the advantage of occupying space to the exclusion of neighbouring plants can be a successful strategy in which early seedling emergence and establishment provide a head start effect in growth (Ross \& Harper 1972, Miller et al. 1994). This has been proven to apply similarly for woody species. For example, Seiwa (2000) investigated the importance of seed size and emergence time depending on the growth phenology of tree species, i.e. either the flush type with simultaneous leaf production and height growth in a short period 
irrespective of environmental conditions, or the more continuously growing, i.e. the succeeding, type that pursues vertical growth and repeated leaf emergence for a longer period. The author concluded that compensatory growth effects for species with succeeding growth phenology is an effect of earlier seedling emergence.

The relevance of rapid germination for the invasion success of Rhododendron ponticum has to be evaluated in the context of the appropriate climatic conditions in the invaded area. In their comparative analysis of climatic and edaphic conditions of natural and invaded Rhododendron sites in Georgia, Spain and Ireland, Erfmeier \& Bruelheide (2004b) presumed that the lower seasonal temperature amplitude and the absence of extreme temperature maxima in the summer in the invaded area decreased the probability and thus the risk of being affected by summer drought periods. Consequently, it can be assumed that a selection towards precautious germination is less effective in the invasion area, but that it is of greater importance, e.g., in Spanish rhododendron populations that are at risk of being exposed to regular drought periods during the phase of seedling emergence (Mejías et al. 2002).

It is plausible that the life strategy of Georgian rhododendron comprises a maximised distribution of risks over time including higher investment in persistence than in rapid responses. This is particularly reflected in these genotypes' delayed germination at cold temperatures. This precautious germination response at warmest and coldest temperature conditions can be interpreted as adaptation to an unreliable environment exhibiting sudden frost events or drought episodes (Thomas et al. 1994; Keller \& Kollmann 1999), or, perhaps, to unfavourable nutrient conditions, as described for Georgian rhododendron sites (Erfmeier \& Bruelheide 2004b). Initially retarded germination does provide the possibility of opportunistic responses subsequent to disturbance events that have altered and temporarily ameliorated the site conditions (Grime 1979). This is very much in accordance with our findings of higher Rhododendron ponticum germination rates in Georgian predispersal seed bank samples than in Spanish and Irish ones (unpublished data). The risk of experiencing severe losses, in contrast, is comparatively low for invasive genotypes in the new habitat, as the new site is characterised by low seasonal temperature variability and opportune edaphic conditions (Erfmeier \& Bruelheide 2004b).

\section{Preconditioning effects}

Parental environments can typically influence the phenotype of the offspring, including, in particular, germination patterns (Meyer \& Allen 1999). For example, Galloway (2001) could show that increasing maternal nutrient and light levels significantly decreased the percentage of germination in Campanula americana; whilst paternal environments affected both percentage and 
timing of germination. For the present results, parental effects have to be taken into consideration as the maturation of the utilised seed material in the field had occurred under significantly different conditions with respect to parental nutrient supply and microclimate (see Erfmeier \& Bruelheide 2004b). There is also a general trend of within-species seed mass variation along latitudinal gradients. Murray et al. (2004) found larger seed mass at low latitudes for 34 perennial Glycine taxa,. The authors attribute this result to higher metabolic costs due to increased temperature and solar radiation.

We are aware that these circumstances limit the comparability of the origins to some extent and that a more precise distinction between parental environment and genotypic effects would have to refer to seed material derived from individuals grown under identical conditions (Baskin \& Baskin 1998). Since the life-form of Rhododendron ponticum as a persistent woody plant prevents the species' fast experimental reproduction, satisfying this claim could not be realised in this project's time frame. However, intensified breeding efforts with Rhododendron individuals have already exhibited the first flowering events, thus showing promise for future studies.

\section{Growth rates}

Growth characteristics revealed clear genetic differences and a resulting superiority of the invasive genotypes. High growth rates combined with the small number of internodes that we found in the invasive Irish individuals can be seen as an indication of selection for rapid growth. Stem elongation is assumed to enhance fitness by improving the plant's competitive ability for light as a shade avoidance strategy (Weinig 2000) and an increase in shoot length is a frequently encountered trait of plant invaders (Williams et al. 1995; Reich et al. 1998; Baruch et al. 2000; Grotkoop et al. 2002). In their comparative and experimental study on growth pattern, biomass allocation and photosynthesis of invasive and native Hawaiian species, Pattison et al. (1998) found genotypic evidence for higher growth rates in the invasive species, particularly at low light conditions. The authors suggest that specific photosynthetic adaptations to capturing and utilizing light resources are effective in invasive plants. The inclusion of physiological parameters might be rewarding for Rhododendron ponticum. In a comparison of each one native and invasive Rhododendron ponticum population on leaf-level phenotypic variability, Niinemets et al. (2003) suggested an increased investment of foliar $\mathrm{N}$ in photosynthetic components to contribute to the species' invasive nature.

In any event, independently of the nature of the underlying driving mechanism, a variation in RGR is often associated with a shift in biomass allocation (Villar \& al. 1998), resulting in changes in the root-shoot ratio of biomass. The present study provides no information on such a biomass allocation pattern, but additional growth experiments with Rhododendron seedlings indicate a shift towards 
increased shoot investment in individuals of invasive origin (unpublished data). A lower investment in root biomass compared to shoot investment in invasive populations supports the idea of a putative release from competitive stress. The resulting pattern of invasive and native Rhododendron origins differing in life strategies is very much in accordance with Grime’s C-S-R-model of primary plant strategies (Grime 1979). Correspondingly, the invasive Irish genotypes in the new area could be attributed to be more ruderal $(\mathrm{R})$ and competitive $(\mathrm{C})$ and less stress tolerating $(\mathrm{S})$ than native Spanish and Georgian plants are. The ability to translate enhanced resources, and compared to native Rhododendron sites in Georgia and Spain the invaded sites are characterised by elevated resource levels (Erfmeier \& Bruelheide 2004b), into rapid growth and early reproduction seems to have an adaptive value in a predictable environment.

\section{Mechanisms involved}

The attempt to assess involved mechanisms that have contributed to the encountered genetic differences between native and invasive populations needs to consider different explanation models that might apply.

Escape theories are currently often employed to explain a species' successful spread. Some recent approaches use the enemy release hypothesis, i.e. the escape from natural antagonists (Maron \& Vilà 2001; Keane \& Crawley 2002); whilst others include the release from co-evolved competitors in the home range (Callaway \& Aschehough 2000; Reinhart et al. 2003), sometimes comprising allelopathic effects that operate in a new community, which, in turn, is more sensitive to the chemical processes (Hierro \& Callaway 2003). However, the general idea behind these assumptions is mostly the absence of the selection pressures that the invaders experienced in their home range. It is possible that similar regulative processes also apply to Rhododendron, for we found evidence of leaf herbivory in both the native and the invaded range, but this occurred to a lesser extent in the new area (personal observation). A trade-off between reduced costs in enemy regulation and increased investment in vegetative growth could then be a specific adaptation to the new environment.

Deviating properties of invasive populations in germination responses and growth rates could also be interpreted as altered ecological or morphological traits resulting from introgression. Hybridisation effects can thus be considered to explain new genotypes (Ellstrand \& Schierenbeck 2000; Lee 2002). For Rhododendron ponticum, Milne \& Abbott (2000) could demonstrate that hybridisation with closely related North American species that had similarly been introduced to Great Britain for horticultural purposes has probably occurred and might thus account for the detected differences. In any event, in our studies of native European and North-American 
populations of Rhododendron ponticum, $R$. maximum, $R$. catawbiense and of invasive Irish Rhododendron populations, we found no such evidence for introgression with North American material.

However, a deeper understanding of underlying selection mechanisms, which might include selection on numerous hybrid combinations (Lee 2002), is beyond the scope of this article and would have to be studied with appropriate methods of molecular genetics.

\section{Acknowledgements}

Acquisition of plant and seed material was possible thanks to friendly support from Zurab Manvelidze, Botanical Garden Batumi (Georgia), Felipe Oliveros, director of the Los Alconorcales Natural Parc (Spain), and the staff from Killarney and Wicklow National Parks (Ireland). We thank Marina Tsaliki, Christel Roß, Catharina Meinen, Christian Sonntag and Brit Ködderitzsch for their support in data collection. We gratefully acknowledge the discussion on the statistics and the manuscript with Christian Kluth. The project was realised thanks to a grant of the German Research Foundation DFG (BR 1698/3) 


\section{Literatur}

Albert, M.E., D'Antonio, C.M. \& Schierenbeck, K.A. (1997) Hybridization and introgression in Carpobrotus spp. (Aizoaceae) in California: I. Morphological evidence. American Journal of Botany, 84, 896-904.

Alpert, P., Bone, E. \& Holzapfel, C. (2000) Invasiveness, invasibility and the role of environmental stress in the spread of non-native plants. Perspectives in Plant Ecology, Evolution and Systematics, 3, 52-66.

Anttila, C.K., Daehler, C.C., Rank, N.E. \& Strong, D.R. (1998) Greater male fitness of a rare invader (Spartina alterniflora, Poaceae) threatens a common native (Spartina foliosa) with hybridization. American Journal of Botany, 85, 1597-1601.

Ayres, D.R., Garcia-Rossi, D., Davis, H.G. \& Strong, D.R. (1999) Extent and degree of hybridization between exotic (Spartina alterniflora) and native (S. foliosa) cordgrass (Poaceae) in California, USA determined by random amplified polymorphic DNA (RAPDs). Molecular Ecology, 8, 1179-1186.

Baker, H.G. (1974) The evolution of weeds. Annual Reviewof Ecology and Systematics, 5, 1-24.

Baker, H.G. \& Stebbins, G.L. (1965) The genetics of colonizing species. Academic Press, New York.

Barrett, S.C.H. \& Richardson, B.J. (1986) Genetic attributes of invading species. Ecology of biological invasions (eds R. H. Groves \& J. J. Burdon), pp. 21-33. Cambridge University Press, Cambridge.

Baruch, Z. \& Goldstein, G. (1999) Leaf construction cost, nutrient concentration, and net $\mathrm{CO}_{2}$ assimilation of native and invasive species in Hawaii. Oecologia, 121, 183-192.

Baruch, Z., Pattison, R.R. \& Goldstein, G. (2000) Responses to light and water availability of four invasive Melastomataceae in the Hawaiian islands. International Journal of Plant Sciences, 161, 107-118.

Baskin, C.C. \& Baskin, J.M. (1998) Seeds. Ecology, biogeography, and evolution of dormancy and germination. Academic Press, San Diego, London, Boston, New York, Sydney, Tokyo, Toronto.

Bastlová, D. \& Kvet, J. (2002) Differences in dry weight partitioning and flowering phenology between native and non-native plants of purple loosestrife (Lythrum salicaria L.). Flora, 197, 332-340.

Bastlová-Hanzélyová, D. (2001) Comparative study of native and invasive populations of Lythrum salicaria: population characteristics, site and community relationships. Plant invasions: species ecology and ecosystem management (eds G. Brundu, J. Brock, I. Camarda, L. Child, \& M. Wade), pp. 33-40. Backhuys Publisher, Leiden.

Bean, W.J. (1976) Trees and shrubs hardy in the British Isles. John Murray, London.

Beckstead, J., Meyer, S.E. \& Allen, P.S. (1996) Bromus tectorum seed germination: between-population and between-year variation. Canadian Journal of Botany, 74, 875-882.

Beerling, D.J. (1993) The impact of temperature on the distribution limits of the introduced species Fallopia japonica and Impatiens glandulifera in north-west Europe. Journal of Biogeography, 20, 45-53.

Beerling, D.J., Huntley, B. \& Bailey, J.P. (1995) Climate and the distribution of Fallopia japonica: use of an introduced species to test the predictive capacity of response surfaces. Journal of Vegetation Science, 6 , 269-282.

Bímová, K., Mandák, B. \& Pyšek, P. (2003) Experimental study of vegetative regeneration in four invasive Reynoutria taxa (Polygonaceae). Plant Ecology, 166, 1-11.

Blanca, G., Cabezudo, B., Hernández-Bermejo, J.E., Herrera, C.M., Muñoz, J. \& Valdés, B. (2000) El libro rojo de las especies de flora amenazada en Andalucía. Consejería de Medio Ambiente de la Junta de Andalucía, Sevilla.

Blossey, B. \& Nötzold, R. (1995) Evolution of increased competitive ability in invasive nonindigenous plants: a hypothesis. Journal of Ecology, 83, 887-889. 
Brändle, M., Stadler, J., Klotz, S. \& Brandl, R. (2003) Distributional range size of weedy plant species is correlated to germination patterns. Ecology, 84, 136-144.

Bruelheide, H. (1999) Experiments as a tool to investigate plant range boundaries. Verhandlungen der Gesellschaft für Ökologie, 29, 26.

Brunner, E. \& Puri, M.L. (2001) Nonparametric methods in factorial designs. Statistical papers, 42, 1-52.

Buckley, Y.M., Downey, P., Fowler, S.V., Hill, R., Memmot, J., Norambuena, H., Pitcairn, M., Shaw, R., Sheppard, A.W., Winks, C., Wittenberg, R. \& Rees, M. (2003) Are invasives bigger? A global study if seed size variation in two invasive shrubs. Ecology, 84, 1434-1440.

Burke, M.J.W. \& Grime, J.P. (1996) An experimental study of plant community invasibility. Ecology, 77, 776-790.

Cabin, R.J., Evans, A.S. \& Mitchell, R.J. (1997) Genetic effects on germination timing and environment: an experimental investigation. Evolution, 51, 1427-1434.

Callaway, R.M. \& Aschehough, E.T. (2000) Invasive plants versus their new and old neighbours: a mechanism for exotic invasion. Science, 290, 521-523.

Castroviejo, S. et al. (1993) Flora Iberica. Plantas vasculares de la península Ibérica y Islas Baleares. Vol. IV Cruciferae - Monotropaceae. Real Jardín Botánico, Madrid.

Clapham, A.R., Tutin, T.G. \& Moore, D.M. (1987) Flora of the British Isles. Cambridge University Press, Cambridge.

Clay, K. \& Levin, D.A. (1986) Environment-dependent intraspecific competition in Phlox drummondii. Ecology, 67, 37-45.

Cornelissen, J.H.C., Castro-Díez, P. \& Carnelli, A.L. (1998) Variation in relative growth rate among woody species. Inherent variation in plant growth (eds H. Lambers, H. Poorter, \& M. M. I. van Vuuren), pp. 363-392. Backhuys Publishers, Leiden.

Cox, G.W. (1999) Alien species in North America and Hawaii: impacts on natural ecosystems. Island Press, Washington DC.

Cox, P.A. (1979) The larger species of Rhododendron. BT Batsford Ltd, London.

Cox, P.A. \& Hutchinson, P. (1963) Rhododendrons in north east Turkey. London.

Craine, J.M. \& Lee, W.G. (2003) Covariation in leaf and root traits for native and non-native grasses along an altitudinal gradient in New Zealand. Oecologia, 134, 471-478.

Crawley, M.J. (1987) What makes a community invasible? Colonization, succession and stability. (eds A. J. Gray, M. J. Crawley, \& P. J. Edwards), pp. 429-453. Blackwell, Oxford.

Cronk, Q.C.B. \& Fuller, J.L. (1995) Plant Invaders - The threat to natural ecosystems. Chapman \& Hall, London, Glasgow, Weinheim, New York, Tokyo, Melbourne, Madras.

Cross, J.R. (1975) Biological Flora of the British Isles. Rhododendron ponticum L. Journal of Ecology, 63, 345-364.

Cross, J.R. (1981) The establishment of Rhododendron ponticum in the Killarney oakwoods, S.W. Ireland. Journal of Ecology, 69, 807-824.

Davis, M.A., Grime, J.P. \& Thompson, K. (2000) Fluctuating resources in plant communities: a general theory of invasibility. Journal of Ecology, 88, 528-534.

Davis, P.H. (1978) Flora of Turkey. University Press, Edinburgh.

Drake, J.A., Mooney, H.A., di Castri, F., Groves, R.H., Kruger, F.J., Rejmánek, M. \& Williamson, M. (1989) Biological invasions. A global perspective. John Wiley \& Sons, Chichester.

Eckert, C.G., Manicacci, D. \& Barrett, S.C.H. (1996) Genetic drift and founder effect in native versus introduced populations of an invading plant, Lythrum salicaria (Lythraceae). Evolution, 50, 1512-1519. 
Edwards, K.R., Kvet, J. \& Adams, M.S. (1999) Comparison of Lythrum salicaria L. study sites in the Midwest U.S. and Central Europe. Ekologia Bratislava, 18, 113-124.

Ehrenfeld, J.G. (2003) Effects of exotic plant invasions on soil nutrient cycling processes. Ecosystems, 6, 503-523.

Ellstrand, N.C. \& Schierenbeck, K.A. (2000) Hybridization as a stimulus for the evolution of invasiveness in plants? Proceedings of the National Academy of Sciences of the United States of America, 97, 70437050.

Elton, C.S. (1958) The ecology of invasions by animals and plants. Methuen, London.

Erfmeier, A. \& Bruelheide, H. (2004a) Comparison of native and invasive Rhododendron ponticum populations: Growth, reproduction and morphology under field conditions. Flora, 199, 120-133.

Erfmeier, A. \& Bruelheide, H. (2004b) Invasibility or invasiveness? Effects of habitat, genotype, and their interaction on invasive Rhododendron pontiucm (Ericaceae) in the British Isles. Journal of Ecology, submitted.

Esen,D. (2000) Ecology and control of Rhododendron (Rhododendron ponticum L.) in turkish eastern beech (Fagus orientalis Lipsky) forests. Dissertation thesis, Faculty of the Virginia Polytechnic Institute and State University.

Fritsche, F. \& Kaltz, O. (2000) Is the Prunella (Lamiaceae) hybrid zone structured by an environmental gradient? Evidence from a reciprocal transplant experiment. American Journal of Botany, 87, 995-1003.

Galloway, L.F. (2001) The effect of maternal and paternal environments on seed characters in the herbaceous plant Campanula americana (Campanulaceae). American Journal of Botany, 88, 832-840.

Galloway, L.F. \& Fenster, C.B. (2000) Population differentiation in an annual legume: local adaptation. Evolution, 54, 1173-1181.

Gaskin, J.F. \& Schaal, B.A. (2002) Hybrid Tamarix widespread in U.S. invasion and undetected in native Asian range. Proceedings of the Natural Academy of Science, 99, 11256-11259.

Gray, A.J. (1986) Do invading species have definable genetic characteristics? Philosophical Transactions of the Royal Society London, B, 655-674.

Grigulis, K., Sheppard, A.W., Ash, J.E. \& Groves, R.H. (2001) The comparative demography of the pasture weed Echium plantagineum between its native and invaded ranges. Journal of Applied Ecology, 38, 281-290.

Grime, J.P. (1979) Plant strategies and vegetation processes. Wiley, Chichester.

Grime, J.P., Mason, G., Curtis, A.V., Rodman, J., Band, S.R., Mowforth, M.A.G., Neal, A.M. \& Shaw, S. (1981) A comparative study of germination characteristics in a local flora. Journal of Ecology, 69, 1017-1059.

Gritten, R.H. (1995) Rhododendron ponticum and some other invasive plants in the Snowdonia National Park. Plant Invasions - General Aspects and Special Problems (eds P. Pyšek, K. Prach, M. Rejmánek, \& M. Wade), pp. 213-219. SPB Academic Publishing, Amsterdam.

Grotkoop, E., Rejmánek, M. \& Rost, T.L. (2002) Toward a causal explanation of plant invasiveness: seedling growth and life-history strategies of 29 pine (Pinus) species. The American Naturalist, 159, 396-419.

Hierro, J.L. \& Callaway, R.M. (2003) Allelopathy and exotic plant invasion. Plant and Soil, 256, 29-39.

Hobbs, R.J. \& Atkins, L. (1988) Effect of disturbance and nutrient addition on native and introduced annuals in plant communities in the Western Australian wheatbelt. Australian Journal of Ecology, 13, 171-179.

Hoopes, M.F. \& Hall, L.M. (2002) Edaphic factors and competition affect pattern formation and invasion in a California grassland. Ecological Applications, 12, 24-39. 
Huenneke, L.F., Hamburg, S.P., Koide, R., Mooney, H.A. \& Vitousek, P.M. (1990) Effects of soil resources on plant invasion and community structure in Californian serpentine grassland. Ecology, 71, 478-491.

Hufford, K.M. \& Mazer, S.J. (2003) Plant ecotypes: genetic differentiation in the age of ecological restoration. Trends in Ecology and Evolution, 18, 147-155.

Jäger, E.J. (1988) Möglichkeiten der Prognose synanthroper Pflanzenausbreitungen. Flora, 180, 101-131.

Jakobs, G., Weber, E. \& Edwards, P.J. (2004) Introduced plants of the invasive Solidago gigantea (Asteraceae) are larger and grow denser than conspecifics in the native range. Diversity and Distribution, 10, 11-19.

Jessen, K., Andersen, S.T. \& Farrington, A. (1959) The interglacial deposit near Gort, Co. Galway, Ireland. Proceedings of the Royal Irish Academy, 60, 1-77.

Joshi, J., Schmid, B., Caldeira, M.C., Dimitrakopoulos, P.G., Good, J., Harris, R., Hector, A., Huss-Danell, K., Jumpponen, A., Minns, A., Mulder, C.P.H., Pereira, J.S., Prinz, A., Scherer-Lorenzen, M., Siamantziouras, A.-S.D., Terry, A.C., Troumbis, A.Y. \& Lawton, J.H. (2001) Local adaptation enhances performance of common plant species. Ecology Letters, 4, 536-544.

Keane, R.M. \& Crawley, M.J. (2002) Exotic plant invasions and the enemy release hypothesis. Trends in Ecology and Evolution, 17, 164-170.

Keller, M. \& Kollmann, J. (1999) Effects of seed provenance on germination of herbs for agricultural compensation sites. Agriculture, Ecosystems and Environment, 72, 87-99.

Klironomos, J.N. (2002) Feedback with soil biota contributes to plant rarity and invasiveness in communities. Nature, 417, 67-70.

Kolar, C.S. \& Lodge, D.M. (2001) Progress in invasion biology: predicting invaders. Trends in Ecology and Evolution, 16, 199-204.

Kowarik, I. (1995) Time lags in biological invasions with regard to the success and failure of alien species. Plant Invasions - General Aspects and Special Problems (eds P. Pyšek, K. Prach, M. Rejmánek, \& M. Wade), pp. 15-38. SPB Academic Publishing, Amsterdam.

Lavorel, S., Prieur-Richard, A.-H. \& Grigulis, K. (1999) Invasibility and diversity of plant communities: from patterns to processes. Diversity and Distribution, 5, 41-49.

Lee, C.E. (2002) Evolutionary genetics of invasive species. Trends in Ecology and Evolution, 17, 386-391.

Leger, E.A. \& Rice, K.J. (2003) Invasive California poppies (Eschscholzia californica Cham.) grow larger than native individuals under reduced competition. Ecology Letters, 6, 257-264.

Li, Y. \& Norland, M. (2001) The role of soil fertility in invasion of brazilian pepper (Schinus terebinthifolius) in Everglades National Park, Florida. Soil Science, 166, 400-405.

Lodge, D.M. (1993) Biological invasions: lessons for ecology. Trends in Ecology and Evolution, 8, 133-137.

Lonsdale, W.M. (1999) Global patterns of plant invasions and the concept of invasibility. Ecology, 80, 15221536.

Mack, R.N. (1996) Predicting the identity and fate of plant invaders: emergent and emerging approaches. Biological Conservation, 78, 107-121.

Mack, R.N., Simberloff, D., Lonsdale, W.M., Evans, H., Clout, M. \& Bazzaz, F.A. (2000) Biotic invasions: cause, epidemiology, global consequences, and control. Ecological Applications, 10, 689-710.

Mandák, B. (2003) Germination requirements of invasive and non-invasive Atriplex species: a comparative study. Flora, 198, 45-54.

Maron, M. \& Vilà, M. (2001) When do herbivores affect plant invasion? Evidence for the natural enemies and biotic resistance hypotheses. Oikos, 95, 361-373.

Marschner, H. (1995) Mineral nutrition of higher plants. Academic Press, London, San Diego, New York, Boston, Sydney, Tokyo, Toronto. 
Martins, P.S. \& Jain, S.K. (1979) Role of genetic variation in the colonizing ability of rose clover (Trifolium hirtum All.). The American Naturalist, 114, 591-595.

McGraw, J.B. \& Antonovics, J. (1983) Experimental ecology of Dryas octopetala ecotypes I.Ecotypic differentiation and life-cycle stages of selection. Journal of Ecology, 71, 879-897.

Mejías, J.A., Arroyo, J. \& Ojeda, F. (2002) Reproductive ecology of Rhododendron ponticum (Ericaceae) in relict Mediterranean populations. Botanical Journal of the Linnean Society, 140, 297-311.

Mennema, J., Quené-Boterenbrood, A.J. \& Plate, C.L. (2000) Atlas van de nederlandse flora 2. Bohn, Scheltema, Holkema, Utrecht.

Meusel, H., Jäger, E., Rauschert, S. \& Weinert, E. (1978) Vergleichende Chorologie der zentraleuropäischen Flora. Band II.Karten. Fischer, Jena.

Meyer, S.E. \& Allen, P.S. (1999) Ecological genetics of seed germination regulation in Bromus tectorum L. I. Phenotypic variance among and within populations. Oecologia, 120, 27-34.

Mihulka, S. \& Pyšek, P. (2001) Invasion history of Oenothera congeners in Europe: a comparative study of spreading rates in the last 200 years. Journal of Biogeography, 28, 597-609.

Milbau, A., Nijs, I., Van Peer, L., Reheul, D. \& De Cauwer, B. (2003) Disentangling invasiveness and invasibility during invasion in synthesized grassland communities. New Phytologist, 159, 657-667.

Miller, T.M., Winn, A.A. \& Shemske, D.W. (1994) The effects of density and spatial distribution on selection for emergence time in Prunella vulgaris (Lamiaceae). American Journal of Botany, 81, 1-6.

Milne, R.I. \& Abbott, R.J. (2000) Origin and evolution of invasive naturalized material of Rhododendron ponticum L. in the British Isles. Molecular Ecology, 9, 541-556.

Mitchell, G.F. \& Watts, W.A. (1970) The history of the Ericaceae in Ireland during the quaternary epoch. Studies in the vegetational history of the British Isles (eds D. Walker \& R. G. West), pp. 13-22. Cambridge University Press, Cambridge.

Mitchell, R.J., Marrs, R.H., Le Duc, M.G. \& Auld, M.H.D. (1997) A study of succession on lowland heaths in Dorset, southern England: changes in vegetation and soil chemical properties. Journal of Applied Ecology, 34, 1426-1444.

Montalvo, A.M. \& Ellstrand, N.C. (2000) Transplantation of the subshrub Lotus scoparius: Testing the home-site advantage hypothesis. Conservation Biology, 14, 1034-1045.

Mooney, H.A. \& Drake, J.A. (1986) Ecology of biological invasions of North America and Hawaii. Springer, New York, USA.

Mooney, H.A. \& Hobbs, R.J. (2000) Invasive species in a changing world. Island Press, Washington, DC; Covelo, California.

Müller, M.J. (1996) Handbuch ausgewählter Klimastationen der Erde. Forschungsstelle Bodenerosion der Universität Trier, Mertesdorf (Ruwertal).

Murray, B.R., Brown, A.H.D., Dickman, C.R. \& Crowther, M.S. (2004) Geographical gradients in seed mass in relation to climate. Journal of Biogeography, 31, 379-388.

Myers, J.H. \& Bazely, D. (2003) Ecology and control of introduced plants. Cambridge University Press, Cambridge.

Nagel, J.M. \& Griffin, K.L. (2001) Construction cost and invasive potential: comparing Lythrum salicaria (Lythraceae) with co-occurring native species along pond banks. American Journal of Botany, 88, 22522258.

Niinemets, Ü., Valladares, F. \& Ceulemans, R. (2003) Leaf-level phenotypic variability and plasticity of invasive Rhododendron ponticum and non-invasive Ilex aquifolium co-occurring at two contrasting European sites. Plant Cell and Environment, 26, 941-956. 
Noble, I.R. (1989) Attributes of invaders and the invading process: terrestrial vascular plants. The ecology of biological invasions: a global perspective (eds J. A. Drake, H. A. Mooney, F. di Castri, R. H. Groves, F. J. Kruger, M. Rejmánek, \& M. Williamson), pp. 301-313. Wiley, Chichester.

Orr, H.A. \& Coyne, J.A. (1992) The genetics of adaptation: a reassessment. The American Naturalist, 140, 725-742.

Parker, I.M., Rodriguez, J. \& Loik, M.E. (2003) An evolutionary approach to understanding the biology of invasions: local adaptation and general-purpose genotypes in the weed Verbascum thapsus. Conservation Biology, 17, 59-72.

Parker, I.M., Simberloff, D., Lonsdale, W.M., Goodell, K., Wonham, M., Kareiva, P., Williamson, M.H., von Holle, B., Moyle, P.B., Byers, J.E. \& Goldwasser, L. (1999) Impact: toward a framework for understanding the ecological effects of invaders. Biological Invasions, 1, 3-19.

Pattison, R.R., Goldstein, G. \& Ares, A. (1998) Growth, biomass allocation and photosynthesis of invasive and native Hawaiian rainforest species. Oecologia, 117, 449-459.

Paynter, Q., Downey, P.O. \& Sheppard, A.W. (2003) Age structure and growth of the woody legume weed Cytisus scoparius in native and exotic habitats: implications for control. Journal of Applied Ecology, 40, 470-480.

Paynter, Q., Fowler, S.V., Memmott, J. \& Sheppard, A.W. (1998) Factors affecting the establishment of Cytisus scoparius in southern France: implications for managing both native and exotic populations. Journal of Applied Ecology, 35, 582-595.

Perrins, J., Fitter, A. \& Williamson, M. (1993) Population biology and rates of invasion of three introduced Impatiens species in the British Isles. Journal of Biogeography, 33-44.

Perrins, J., Williamson, M. \& Fitter, A. (1992) A survey of differing views of weed classification: implications for regulation of introductions. Biological Conservation, 60, 47-56.

Pornon, A., Escaravage, N., Thomas, P. \& Taberlet, P. (2000) Dynamics of genotypic structure in clonal Rhododendron ferrugineum (Ericaceae) populations. Molecular Ecology, 9, 1099-1111.

Radford, I.J. \& Cousens, R.D. (2000) Invasiveness and comparative life-history traits of exotic and indigenous Senecio species in Australia. Oecologia, 125, 531-542.

Reich, P.B., Tjoelker, M.G., Walters, M.B., Vanderklein, D.W. \& Buschena, C. (1998) Close association of RGR, leaf and root morphology, seed mass and shade tolerance in seedlings of nine boreal tree species grown in high and low light. Functional Ecology, 12, 327-338.

Reinhart, K.O., Packer, A., Van der Putten, W. \& Clay, K. (2003) Plant-soil biota interactions and spatial distribution of black cherry in its native and invasive ranges. Ecology Letters, 6, 1046-1050.

Rejmánek, M. (1995) What makes a species invasive? Plant Invasions - General Aspects and Special Problems (eds P. Pyšek, K. Prach, M. Rejmánek, \& M. Wade), pp. 3-13. SPB Academic Publishing, Amsterdam.

Rejmánek, M. \& Richardson, D.M. (1996) What attributes make some plant species more invasive? Ecology, 77, 1655-1661.

Rice, K.J. \& Mack, R.N. (1991) Ecological genetics of Bromus tectorum: III. The demography of reciprocally sown populations. Oecologia, 88, 91-101.

Rieseberg, L.H. \& Carney, S.E. (1998) Plant hybridization. New Phytologist, 140, 599-624.

Ross, M.A. \& Harper, J.L. (1972) Occupation of biological space during seedling establishment. Journal of Ecology, 60, 77-88.

Sakai, A.K., Allendorf, F.W., Holt, J.S., Lodge, D.M., Molofsky, J., With, K.A., Baughman, S., Cabin, R.J., Cohen, J.E., Ellstrand, N.C., McCauley, D.E., O'Neil, P., Parker, I.M., Thompson, J.N. \& Weller, S.G. (2001) The population biology of invasive species. Ann. Rev. Ecol. Syst., 32, 305-332.

SAS Institute (2000) SAS Procedures guide. Cary, North Carolina, USA. 
Schlichting, C.D. \& Pigliucci, M. (1998) Phenotypic evolution: A reaction norm perspective. Sinauer Associates, Inc., Publishers, Sunderland, Massachussets.

Schulz, C. \& Bruelheide, H. (1999) An experimental study on the impact of winter temperature on the distribution of Euphorbia amygdaloides L. in Central Germany. Recent shifts in vegetation boundaries of deciduous forests, especially due to general global warming (eds F. Klötzli \& G.-R. Walther), pp. 121-150. Birkhäuser Verlag, Basel.

Schweitzer, J.A., Martinsen, G.D. \& Whitham, T.G. (2002) Cottonwoold hybrids gain fitness traits of both parents: a mechanism for their long-term persistence? American Journal of Botany, 89, 981-990.

Seiwa, K. (2000) Effects of seed size and emergence time on tree seedling establishment: importance of developmental constraints. Oecologia, 123, 208-215.

Shaw, M.W. (1984) Rhododendron ponticum - ecological reasons for the success of an alien species in Britain and features that may assist in its control. Aspects of Applied Biology, 5, 231-242.

Shea, K. \& Chesson, P. (2002) Community ecology theory as a framework for biological invasions. Trends in Ecology and Evolution, 17, 170-176.

Sheppard, A.W., Hodge, P., Paynter, Q. \& Rees, M. (2002) Factors affecting invasion and persistence of broom Cytisus scoparius in Australia. Journal of Applied Ecology, 39, 721-734.

Siemann, E. \& Rogers, W.E. (2003) Changes in light and nitrogen availability under pioneer trees may indirectly facilitate tree invasions of grasslands. Journal of Ecology 91: 923-931.

Siemann, E. \& Rogers, W.E. (2001) Genetic differences in growth of an invasive tree species. Ecology Letters, 4, 514-518.

Silvertown, J. \& Charlesworth, D. (2001) Plant population biology. Blackwell Science, London.

Simons, A.M. (2003) Invasive aliens and sampling bias. Ecology Letters, 6, 278-280.

Smith, M.D. \& Knapp, A.K. (2001) Physiological and morphological traits of exotic, invasive exotic and native plant species in tallgrass prairie. International Journal of Plant Science, 162, 785-792.

Stebbins, G.L. (1969) The significance of hybridization for plant taxonomy and evolution. Taxon, 18, 26-35.

Sukopp, H. \& Starfinger, U. (1995) Reynoutria sachalinensis in Europe and in the far east: a comparison of the species ecology and its native and adventive distribution range. Plant Invasions - General Aspects and Special Problems (eds P. Pyšek, K. Prach, M. Rejmánek, \& M. Wade), pp. 151-159. SPB Academic Publishing, Amsterdam.

Sultan, S.E. \& Spencer, H.G. (2002) Metapopulation structure favors plasticity over local adaptation. The American Naturalist, 160, 271-283.

Tabbush, P.M. \& Williamson, D.R. (1987) Rhododendron ponticum as a forest weed. Bulletin Forestry Commission, 73, 1-7.

Thébaud, C., Finzi, A.C., Affre, L., Debussche, M. \& Escarre, J. (1996) Assessing why two introduced Conyza differ in their ability to invade Mediterranean old fields. Ecology, 77, 791-804.

Thébaud, C. \& Simberloff, D. (2001) Are plants really larger in their introduced ranges? The American Naturalist, 157, 231-236.

Thomas, A.G., Lefkovitch, L.P., Woo, S.L., Bowes, G.G. \& Peschken, D.P. (1994) Effect of temperature on germination within and between diploid and tetraploid populations of Matricaria perforata Mérat. Weed Research, 34, 187-198.

Thompson, J.D. (1991) The biology of an invasive plant. Bioscience, 41, 393-401.

Thompson, J.N. (1998) Rapid evolution as an ecological process. Trends in Ecology and Evolution, 13, 329332.

Thompson, K., Bakker, J. \& Bekker, R. (1997) The soil seed bank of North West Europe: methodology, density and longevity. University Press, Cambridge. 
Thompson, K., Hodgson, J.G., Grime, J.P. \& Burke, M.J.W. (2001) Plant traits and temporal scale: evidence from a 5-year invasion experiment using native species. Journal of Ecology, 89, 1054-1060.

Thompson, K., Hodgson, J.G. \& Rich, C.G. (1995) Native and invasive alien plants: more of the same? Ecography, 18, 390-402.

Tuhkanen, S. (1980) Climatic parameters and indices in plant geography. Acta Phytogeographica Suecica 1: 1-110.

Tutin, T.G., Heywood, J.S., Burges, N.A., Moore, D.M., Valentine, D.H., Walters, S.M. \& Webb, D.A. (1972) Flora Europaea. Cambridge University Press, Cambridge.

Usher, M.B. (1986) Invasibility and wildlife conservation: invasive species on nature reserves. Philosophical Transactions of the Royal Society London., B 314, 695-710.

Vitousek, P.M., D'Antonio, C.M., Loope, L.L. \& Westbrooks, R. (1996) Biological invasions as global environmental change. American Scientist, 84, 468-478.

Wade, M., Darby, E.J., Courtney, A.D. \& Caffrey, J.M. (1997) Heracleum mantegazzianum: a problem for river managers in the Republic of Ireland and the United Kingdom. Plant Invasions: Studies from North-America and Europe (eds J. H. Brock, M. Wade, P. Pyšek, \& D. Green), pp. 139-151. Backhuys Publishers, Leiden.

Walter, H. (1968) Die Vegetation der Erde in öko-physiologischer Betrachtung. Band II: Die gemäßigten und arktischen Zonen. Gustav Fischer Verlag, Stuttgart.

Walter, H. \& Straka, H. (1970) Arealkunde (Floristisch-historische Geobotanik). Ulmer, Stuttgart.

Weber, E. (2003) Invasive plant species of the world. A reference guide to environmental weeds. CABI Publishing, Oxon.

Weber, E. \& D'Antonio, C.M. (1999) Phenotypic plasticity in hybridizing Carpobrotus spp. (Aizoaceae) from coastal California and its role in plant invasion. Canadian Journal of Botany, 77, 1411-1418.

Weinig, C. (2000) Differing selection in alternative competitive environments: shade-avoidance responses and germination timing. Evolution, 54, 124-136.

Williams, D.G., Mack, R.N. \& Black, R.A. (1995) Ecophysiology of introduced Pennisetum setaceum on Hawaii: the role of phenotypic plasticity. Ecology, 76, 1569-1580.

Williamson, M. (1996) Biological invasions. Chapman \& Hall, London, Weinheim, New York, Tokyo, Melbourne, Madras.

Williamson, M. (1999) Invasions. Ecography, 22, 5-12.

Williamson, M.H. \& Fitter, A. (1996) The characters of succesful invaders. Biological Conservation, 78, 163-170.

Willis, A.J. \& Blossey, B. (1999) Benign environments do not explain the increased vigour of nonindigenous plants: a cross-continental transplant experiment. Biocontrol Science and Technology, 9, 567-577.

Willis, A.J., Memmott, J. \& Forrester, R.I. (2000) Is there evidence for the post-invasion evolution of incresed size among invasive plant species? Ecology Letters, 3, 275-283.

Willis, A.J., Thomas, M.B. \& Lawton, J.H. (1999) Is the increased vigour of invasive weeds explained by a trade-off between growth and herbivore resistance? Oecologia, 120, 632-640.

Willis, S.G. \& Hulme, P.E. (2002) Does temperature limit the invasion of Impatiens glandulifera and Heracleum mantegazzianum in the UK? Functional Ecology, 16, 530-539.

Woodward, F.I. (1987) Climate and plant distribution. Cambridge University Press, Cambridge.

Yu, Z., Dahlgren, R.A. \& Northup, R.R. (1999) Evolution of soil properties and plant communities along an extreme edaphic gradient. European Journal of Soil Biology, 35, 31-38. 


\section{Zusammenfassung}

Biologische Invasionen haben in den letzten Jahren zunehmend an Bedeutung für Fragen der ökologischen Forschung gewonnen. Der Erfolg sich invasiv ausbreitender Pflanzen kann sowohl durch bestimmte spezifische Merkmale der einwandernden Arten (invasiveness) als auch durch die Anfälligkeit des neuen Habitats für solche Invasionen (invasibility) gesteuert sein. Darüber hinaus sind häufig spezifische Wechselwirkungen zwischen invasiven Populationen einer Art und der Umwelt von Bedeutung. In der vorliegenden Arbeit werden die Bedeutung von Genotyp und Habitat als Ursachen für das invasive Vorkommen der Art Rhododendron ponticum L. auf den Britischen Inseln analysiert.

Rhododendron ponticum ist eine immergrüne Ericaceae mit natürlichen Vorkommen im Gebiet des Schwarzen Meers, im Libanon sowie weiteren natürlichen Beständen auf der Iberischen Halbinsel in Südspanien und Portugal. Die Art wurde 1763 erstmals als Zierstrauch nach Großbritannien eingeführt. Seither haben sich invasive Rhododendron-Bestände im atlantischen Teil Westeuropas, vor allem in Großbritannien und Irland in zahlreichen Lebensgemeinschaften erfolgreich ausgebreitet. Bislang sind einzelne Aspekte der Invasions- und Populationsbiologie von Rhododendron-Vorkommen im Invasions- oder Herkunftsgebiet Gegenstand von Untersuchungen gewesen. Mit dieser Arbeit liegt nun erstmals ein umfassender Vergleich nativer und invasiver Populationen vor, der durch experimentelle Untersuchungen vertieft wird. Jeweils sechs native Rhododendron-Populationen in Georgien und Spanien, sowie sechs invasive Populationen in Irland wurden anhand eines einheitlichen, hierarchischen Beprobungsdesigns untersucht.

In einem komparativen Ansatz wurde das Invasionsmuster erfasst sowie die Standortsbedingungen in den drei Gebieten analysiert und korrelativ die Bedeutung abiotischer Faktoren für den Invasionserfolg eingeschätzt. Experimentell wurde in Gelände und Labor der Frage nach einer genetischen Grundlage für die Invasivität von $R$. ponticum sowie etwaiger Anpassungen an das neue Habitat nachgegangen.

Der systematische Vergleich biometrischer, morphologischer und demographischer Erhebungen auf der Basis von Daten aus drei Untersuchungsjahren an sechs nativen Rhododendron-Populationen in Georgien und Spanien, sowie sechs invasiven Populationen in Irland konnte zeigen, dass sich die invasiven Populationen vor allem durch höhere jährliche Spross-Zuwachsraten und höhere Etablierungsraten der Keimlinge von den nativen Vorkommen unterschieden. Der Vergleich morphologischer Blattmerkmale differenzierte georgische Individuen deutlich von spanischen und irischen und legte die Wahrscheinlichkeit einer iberischen Abstammung der invasiven Populationen nahe. 
Die zweite Untersuchung erfasste mikroklimatische, edaphische und strukturelle Standortsunterschiede der zuvor beschriebenen georgischen, spanischen und irischen RhododendronBestände und konnte zeigen, dass die Populationen im Invasionsgebiet über eine bessere Nährstoffversorgung verfügten als die Populationen im Herkunftsgebiet. Hohe Wachstums- und Etablierungsraten der invasiven Rhododendren im Feld waren dabei positiv mit den Gehalten an austauschbarem Magnesium und Kalium sowie an organischem Kohlenstoff verbunden. Eine große Temperatur-Amplitude im Jahresverlauf korrelierte hingegen negativ mit den Wachstumsraten im Gelände. In einem Verpflanzungsversuch wurden Stecklinge der drei Herkunftsländer in alle drei Länder reziprok rückverpflanzt. Das Invasionsgebiet erwies sich mit den insgesamt höchsten Überlebensraten als das für alle Herkünfte günstigste Habitat. Es ergab sich dabei kein Hinweis auf eine generelle Überlegenheit invasiver Genotypen. Die invasiven irischen Herkünfte zeigten eine positive Reaktion nur auf das Invasionsgebiet und reagierten dort mit hohen Zuwächsen. Die Untersuchung konnte zeigen, dass von den untersuchten Faktoren Habitat, Genotyp und Anpassung den günstigen edaphischen und klimatischen Bedingungen im Invasionsgebiet der höchste Erklärungswert für den Invasionserfolg zukommt.

Die Evidenz eines genetischen Hintergrundes für die erfolgreiche Ausbreitung von $R$. ponticum wurde anhand von Gewächshaus- und Klimakammerversuchen getestet. Keimungsversuche bei vier verschiedenen Temperaturstufen mit Samenmaterial aus allen 18 nativen und invasiven Populationen deckten keine Unterschiede in den absoluten Keimraten auf, jedoch zeigten die Samen invasiver irischer Populationen eine erhöhte Reaktionsbereitschaft und keimten über alle Temperaturstufen am schnellsten. Wachstumsversuche mit Rhododendron-Stecklingen aus nativen und invasiven Populationen ergaben höhere Wachstumsraten der invasiven Herkünfte und belegten somit, dass die im Gelände beobachteten Muster unterschiedlicher Jahreszuwächse zwischen nativen und invasiven Herkünften genetisch fixiert sind.

Diese Unterschiede sind als Ergebnis einer Anpassung an die jeweiligen Umweltbedingungen im Herkunftshabitat zu interpretieren: Ressourcen-Verfügbarkeit und abiotische Habitatfaktoren sind im Invasionsgebiet als Selektionsfaktoren von geringerer Bedeutung als in den natürlichen Verbreitungsgebieten. Dagegen erscheint die Fähigkeit der invasiven Genotypen, vorhandene Ressourcen in schnelles Wachstum und rasche Reproduktion umzusetzen als Anpassung an das Invasionsgebiet. Zusammenfassend lässt sich schließen, dass die günstigen Bedingungen des Habitats und sich daraus ergebende Lebensstrategien der invasiven Populationen die Haupterklärung für den Invasionserfolg von $R$. ponticum darstellen. Inwieweit biotische Faktoren die Begünstigung der neuen Umwelt mitbedingen, muss in weiteren Untersuchungen analysiert werden. 


\section{Danksagung}

Mein besonderer Dank geht an Prof. Dr. Helge Bruelheide, der dieses Projekt initiiert, betreut, in der praktischen Umsetzung im georgischen Winter mitgelitten (aber sich dann auch im kaukasischen Sommer kräftig mitgefreut) und durch zahlreiche motivierende Diskussionen die Arbeit immer wieder vorangetrieben hat. Prof. Dr. Michael Runge danke ich für die freundliche Übernahme des Korreferats und die anfängliche Betreuung der Arbeit. Prof. Dr. Christoph Leuschner sei für die Aufnahme in seine Arbeitsgruppe und für die Bereitstellung des Arbeitsplatzes gedankt.

Der Graduiertenförderung der Universität Göttingen sowie der Deutschen Forschungsgemeinschaft danke ich für die finanzielle Unterstützung des Projektes.

Prof. Dr. Giorgi Nakhutsrishvili, Dr. Nugri Sikharulidze, Dr. Maia Akhalkatsi und Dr. Zurab Manvelidze ermöglichten die Feldarbeiten in Georgien. Nur Dank ihrer fachlichen und logistischen Unterstützung war das Projekt in Georgien umzusetzen. Mein Dank gilt ebenso Dr. Juan Arroyo, Arndt Hampe, sowie Felipe Oliveros und den weiteren Mitarbeiterinnen und Mitarbeitern des Parque Natural Los Alconorcales in Spanien. Prof. Dr. Gerry Doyle, Lord Meath, Dan Kelleher, Paudie O'Leary, Enda Mullen sowie den weiteren Mitarbeiterinnen und Mitarbeitern des Killarney National Park und des Wicklow National Park danke ich für ihre tatkräftige Unterstützung in Irland. Frau Julia Westhoff (Rhododendron-Park Bremen) und Prof. Dr. Wolfgang Spethmann waren behilflich bei Fragen der Rhododendron-Anzucht sowie bei der Flächen-Auswahl in Deutschland. Ihnen allen sei herzlich für ihre Mithilfe und ihr Interesse am Rhododendron-Projekt gedankt!

Prof. Dr. Thomas Friedl und der gesamten EPSAG-Arbeitsgruppe danke ich für die Kooperationen in der AFLP-Thematik und der Möglichkeit der Analysen im Labor.

Klaus Lewejohann danke ich für die Unterstützung bei der Nachbearbeitung der floristischen Belege. Den Gärtnerinnen und Gärtnern des Experimentellen Botanischen Gartens, insbesondere Regina Helbig und Dirk Deilke, danke ich für ihren ständigen Einsatz in der Pflege des Pflanzenmaterials. Bei den Technischen Mitarbeiterinnen und Mitarbeitern, ganz besonders bei Marianne Gscheidlen und Harmut Wildberger, bedanke ich mich herzlich für die Unterstützung bei allen Laborarbeiten. Dr. Heinz Coners hat mir bei vielen unerfreulichen Hard- und Software-Angelegenheiten ein Weiterarbeiten möglich gemacht. Vielen Dank dafür!

Mathias Wegner, Anke Neugebauer, Christoph Benze, Angelika Erfmeier, Friedrich Erfmeier und Svenja Bruns haben wertvolle Unterstützung bei der Durchkämpfung der Rhododendron-Dickichte geleistet und für moralischen Beistand bei allen Aufgaben gesorgt, die sonst noch im Gelände unter nicht immer einfachen Bedingungen zu leisten waren. Herzlichen Dank dafür!

Den zahlreichen studentischen Hilfskräften danke ich für ihren unermüdlichen Einsatz bei Stecklings-, Keimlings- und Keimungsversuchen. Christel Roß und Marina Tsaliki sei zudem für ihre engagierte und interessierte Mitarbeit im Projekt im Rahmen ihrer Diplomarbeiten gedankt, die dem Projekt viele neue Impulse gegeben haben.

Weiterer Dank gebührt der Arbeitsgruppe, insbesondere der Weender "Exklave", die durch ein hervorragendes soziales Gefüge und geteilte Freude an den sprachlichen Kuriositäten dieser Welt stets erfrischende Aspekte in den Arbeitsalltag gebracht hat.

Christoph Fühner danke ich herzlich für die Übernahme der Formatierungsarbeiten, deren Ergebnis ohne sein Eingreifen sicherlich wesentlich weniger geschliffen gewesen wäre.

Barbara Bauer danke ich für stilistische Anmerkungen.

Christian Kluth verdanke ich ganz entscheidende Einblicke in die statistischen Zusammenhänge. Christian, herzlichen Dank für allen Beistand und die zahlreichen Diskussionen zu diesem Thema und zu vielen anderen. Ich hätte mir keinen besseren Zimmergenossen vorstellen können!

Dr. Stephanie Kluth danke ich für alle Korrekturen, Beratungen und die wertvollen Hinweise, welche Gespräche in welchem Rahmen (nicht) zu führen sind! Besten Dank, nicht nur dafür!

Schließlich möchte ich mich bei meinen Freundinnen und Freunden für ihre moralische und praktische Unterstützung - und auch die Verpflegung - besonders in den letzten Wochen bedanken, für ihr Verständnis und für ihr Geschick, in den richtigen Augenblicken die richtigen Fragen zu stellen.

Ein ganz besonderer Dank gilt schließlich meinen Eltern, die mir durch ihr stetes Vertrauen und Verständnis über die gesamte Zeit den Rücken gestärkt haben. Danke! 



\section{Publikationen}

Erfmeier, A. \& H. Bruelheide (2004): Invasive and native Rhododendron ponticum populations: Is there evidence for genotypic differences in germination and growth? (Ecography, submitted)

Erfmeier, A. \& H. Bruelheide (2004): Invasibility or invasiveness? Effects of habitat, genotype, and their interactions on invasive Rhododendron ponticum (Ericaceae) in the British Isles (Journal of Ecology, submitted)

Erfmeier, A. \& H. Bruelheide (2004): Comparison of native and invasive Rhododendron ponticum populations: Growth, reproduction and morphology under field conditions. Flora 199: 120-133

Bruelheide, H., Jandt, U. \& A. Erfmeier (2003): Field studies on invasive Rhododendron ponticum populations in Ireland and potential hybrid partners in Europe and North America. Verhandlungen der Gesellschaft für Ökologie 33: 141.

Roß, C., Erfmeier, A. \& H. Bruelheide (2003): DNA fingerprinting of invasive and natural Rhododendron ponticum L. populations and of potential introgression source taxa. Verhandlungen der Gesellschaft für Ökologie 33: 142.

Erfmeier, A., Tsaliki, M. \& H. Bruelheide (2003): Is plasticity a key factor explaining a species’ invasion success? - Allocation, Plasticity \& Allometry. $16^{\text {th }}$ Annual meeting Plant Population Biology Section of the Gesellschaft für Ökologie, 40.

Erfmeier, A. \& Bruelheide, H. (2002): The invasion success of Rhododendron ponticum L. explained by habitat and genotype. (eds. Klotz, S. \& Kühn, I.) $2^{\text {nd }}$ International Conference of the German Working Group on Biological Invasions - NEOBIOTA, UFZBericht 14: 27.

Erfmeier, A. \& H. Bruelheide (2001): Invasive Rhododendron ponticum on the British Isles: Do site conditions explain its success? - Vegetation and Ecosystem Functions, $44^{\text {th }}$ Symposium of the International Association for Vegetation Science: 86.

Erfmeier, A. \& H. Bruelheide (2001): Native and invasive populations of Rhododendron ponticum: Do different origins show different traits? Evolution and Plasticity in Plant Populations Contributions to the $14^{\text {th }}$ meeting of the Working Group "Population Biology of Plants" (GfÖ -Gesellschaft für Ökologie).

Erfmeier, A. \& H. Bruelheide (2000): Comparison of natural and invasive populations of Rhododendron ponticum in Georgia, Spain and Ireland. - Symposium Plant Population Viability Analysis. $13^{\text {th }}$ annual meeting or the Working Group "Population Biology of Plants”

Erfmeier, A. \& H. Bruelheide (1999): Do vegetation patterns and soil chemistry depend on the same climatic gradient? Verhandlungen der Gesellschaft für Ökologie 29: 27-38 